\title{
Factors and processes influencing streambank erosion along Horseshoe Run in Tucker County, West Virginia
}

\author{
Abigail L. McQueen \\ West Virginia University
}

Follow this and additional works at: https://researchrepository.wvu.edu/etd

\section{Recommended Citation}

McQueen, Abigail L., "Factors and processes influencing streambank erosion along Horseshoe Run in Tucker County, West Virginia" (2011). Graduate Theses, Dissertations, and Problem Reports. 3317. https://researchrepository.wvu.edu/etd/3317

This Thesis is protected by copyright and/or related rights. It has been brought to you by the The Research Repository @ WVU with permission from the rights-holder(s). You are free to use this Thesis in any way that is permitted by the copyright and related rights legislation that applies to your use. For other uses you must obtain permission from the rights-holder(s) directly, unless additional rights are indicated by a Creative Commons license in the record and/ or on the work itself. This Thesis has been accepted for inclusion in WVU Graduate Theses, Dissertations, and Problem Reports collection by an authorized administrator of The Research Repository @ WVU. For more information, please contact researchrepository@mail.wvu.edu. 


\title{
Factors and processes influencing streambank erosion along
} Horseshoe Run in Tucker County, West Virginia

\author{
Abigail L. McQueen \\ A Thesis submitted to the \\ Davis College of Agriculture, Natural Resources, and Design \\ at West Virginia University \\ in partial fulfillment of the requirements \\ for the degree of \\ Master of Science \\ in \\ Forestry
}

Nicolas Zegre, Ph.D., Chair

J. Steven Kite, Ph.D.

J. Todd Petty, Ph.D.

Danny L. Welsch, Ph.D.

Forest Resources Management Program

Division of Forestry and Natural Resources

\author{
West Virginia University \\ Morgantown, WV \\ 2011
}

Keywords: Streambank, Erosion, Prediction, Model, BANCS, BSTEM, Sediment, Restoration, Stabilization, Prioritization 


\title{
Abstract \\ Factors and processes influencing streambank erosion along Horseshoe Run in Tucker County, West Virginia
}

\begin{abstract}
Abby L. McQueen
Factors and processes influencing streambank erosion are not fully understood and combining factors and processes into a model that predicts streambank erosion is difficult. The mechanistic Bank Stability and Toe Erosion Model (BSTEM) and the empirical Bank Assessment of Nonpoint Source Consequences of Sediment (BANCS) model were evaluated to determine their effectiveness at predicting or explaining streambank erosion along Horseshoe Run. BSTEM underpredicted erosion by between 60 and 75\%, but the model was able to provide relative estimates of eroded material and was also able to predict the type of erosion present at most bank sites. Model validation revealed critical shear stress of the bed material to be locally specific and non transferable to neighboring sites on the same stream. The input parameters for the BANCS model may be used to explain the susceptibility of a streambank to erosion. However, careful consideration needs to be given when using streambank and near bank characteristics to predict relative erosion on sections of the same stream with different morphology and potentially different dominant erosional processes. When the streambank parameters were used to group sites independently of erosion, a group of streambanks with moderate rooting depths and densities, low bank angles, and surface protection emerged. This group experienced the least amount of erosion. Regression analysis showed that for noncohesive restored banks that were vulnerable to fluvial erosion, bank angle, bank height, and vegetation parameters were needed to predict susceptibility to erosion. Alternatively, for cohesive banks with non-cohesive bank toe material that were vulnerable to fluvial erosion and mass failure, bank angle, bank material, and near bank depth ratios with an emphasis on bank angle were sufficient parameters to predict susceptibility.
\end{abstract}




\section{Acknowledgements}

I thank the U.S. Environmental Protection Agency and the USDA Agricultural Research Service for funding this study. I would also like to thank my committee chair, Dr. Nicolas Zegre, for guiding me through this process. I also thank Dr. Danny Welsch and the rest of the staff at Canaan Valley Institute for their support, encouragement, and assistance in the field. Thank you to Dr. Jonathan Cummings for his support, Dr. Phil Turk and Dr. George Merovich for making statistics interesting and understandable, and Dr. Jim Rentch for sharing his knowledge of forest resources and the vegetation of West Virginia. And, of course, I thank my family and friends. 


\section{Table of Contents}

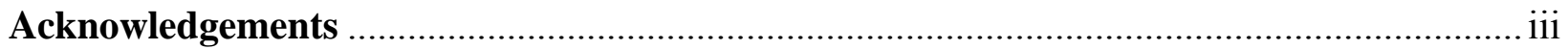

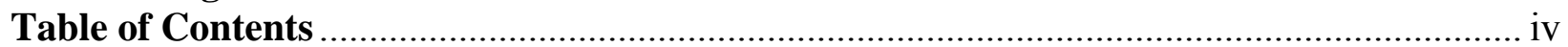

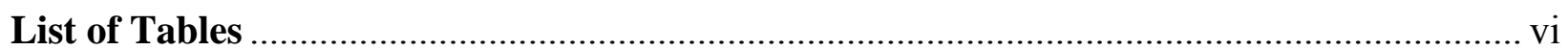

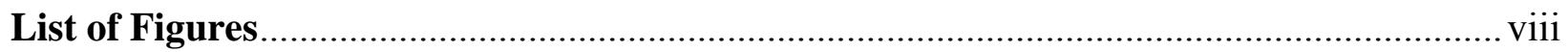



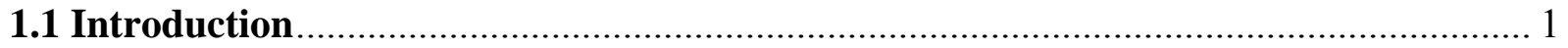

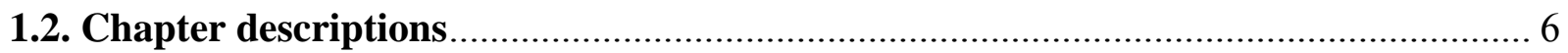

2. The calibration and testing of the physically-based streambank erosion model BSTEM at

Horseshoe Run, Tucker County, West Virginia ....................................................... 14



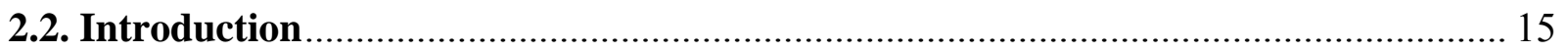

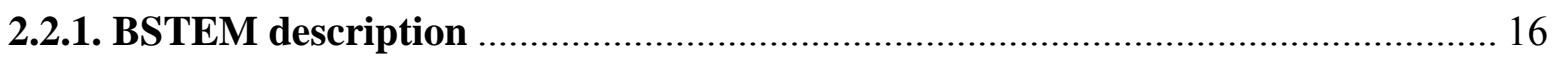

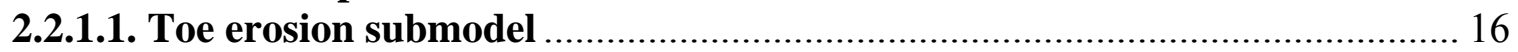



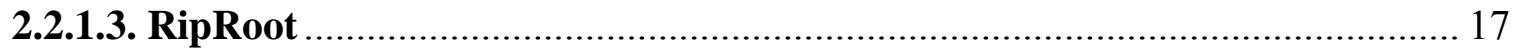



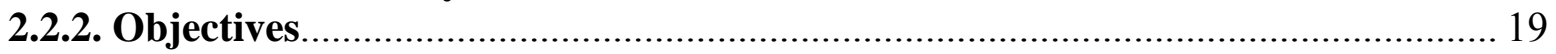

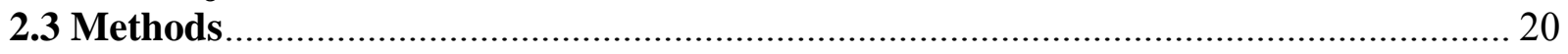

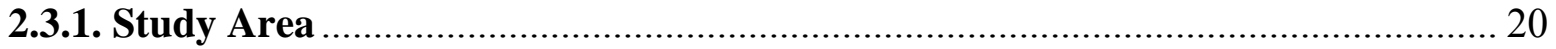



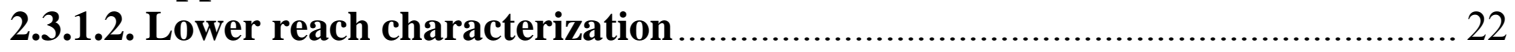

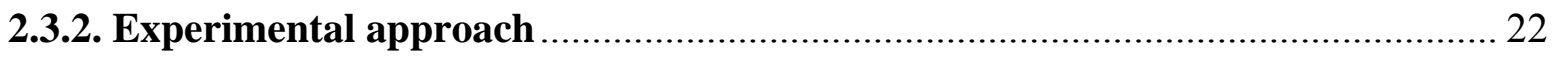

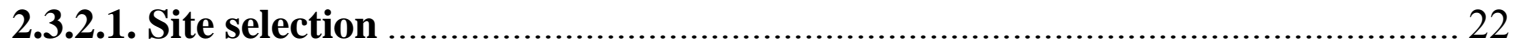

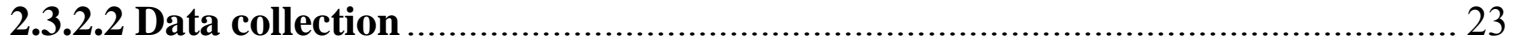

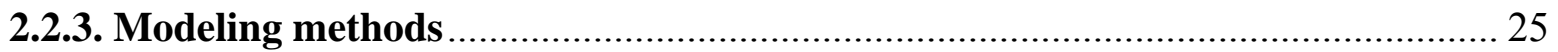

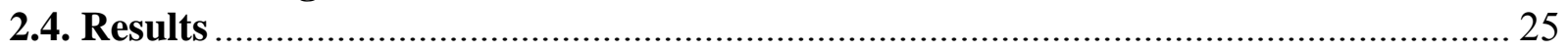

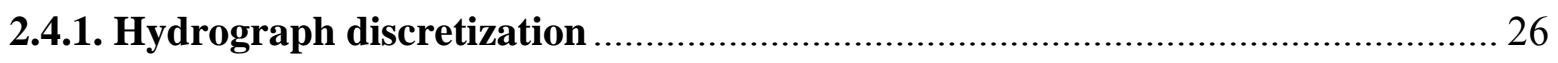

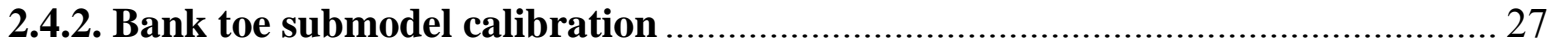

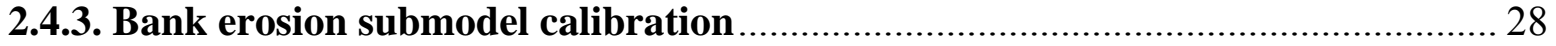

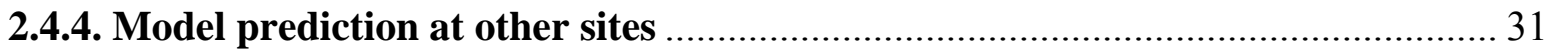

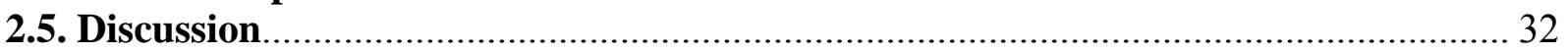



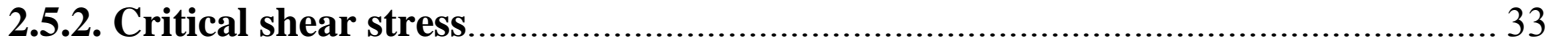

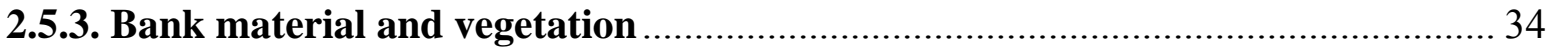



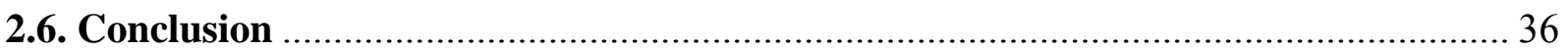

3. Can the BANCS model parameters be used to predict streambank erosion at contrasting reaches: A case study at Horseshoe Run in Tucker County, West Virginia? .................... 65

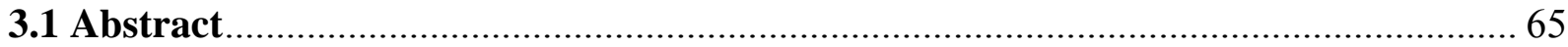

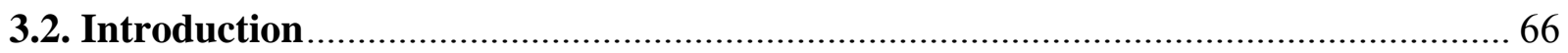

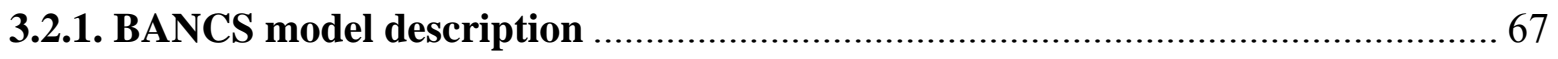

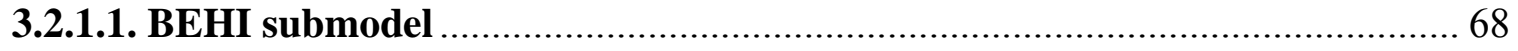

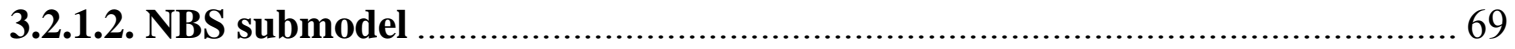

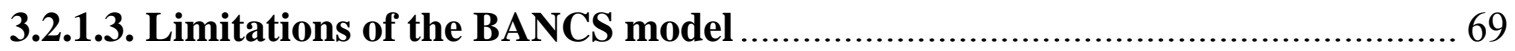


3.3. Methods

3.3.1. Study area

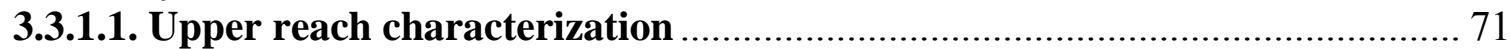

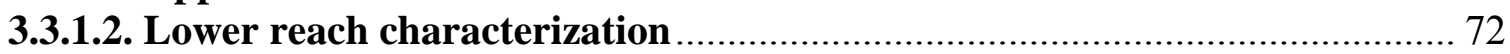

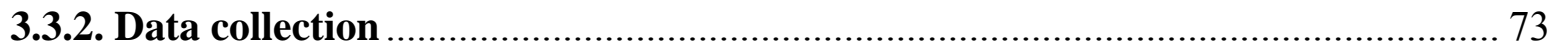

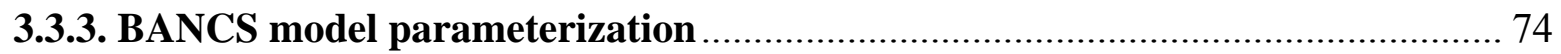

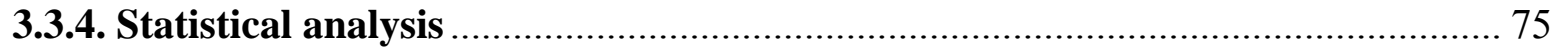

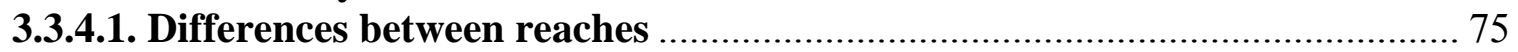

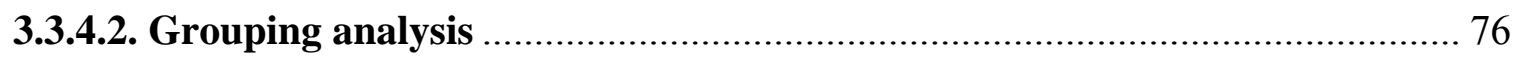

3.3.4.3. Streambank erosion prediction parameters ................................................. 76



3.4.1. Streamflow, precipitation, and measured erosion ………................................... 77

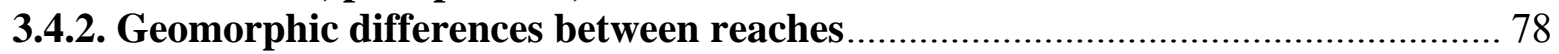

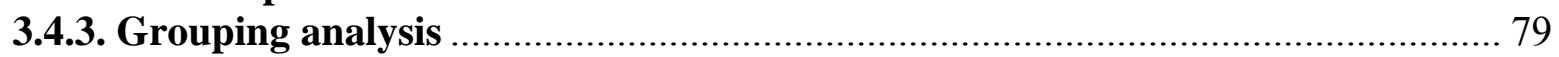

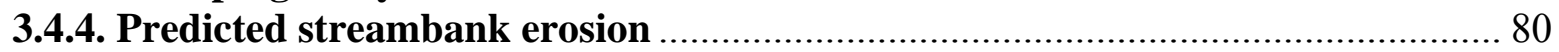

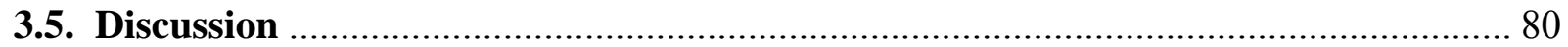

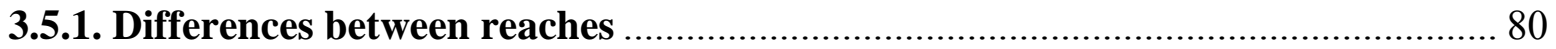

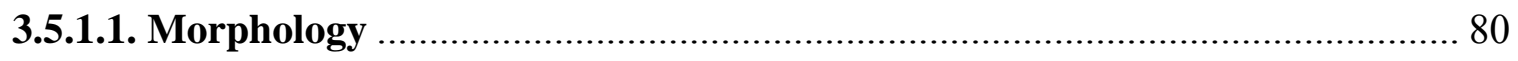

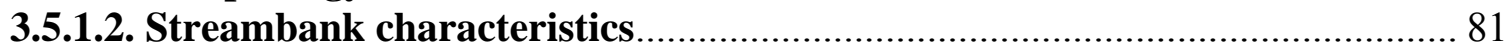





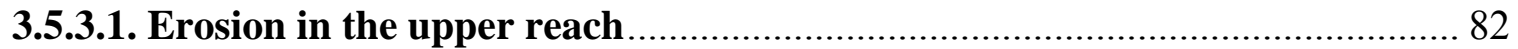

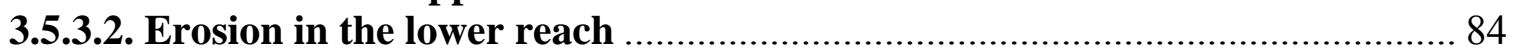

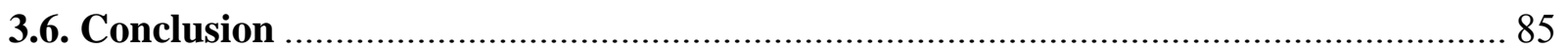

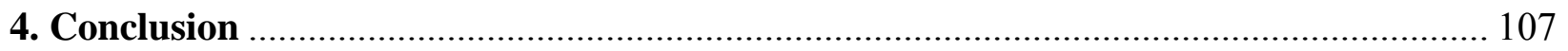

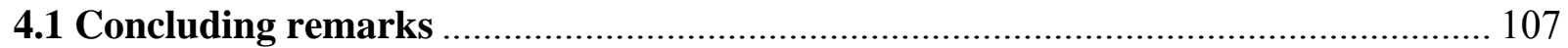

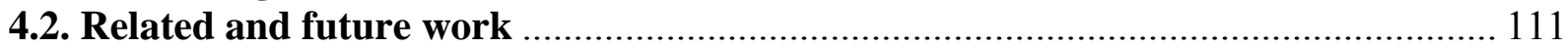

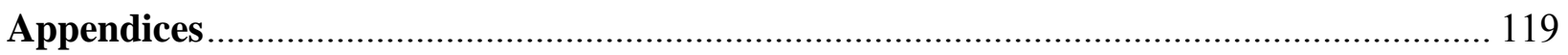




\section{List of Tables}

Table 2.1: BSTEM parameters with definitions, units, and identification of whether the parameter was measured, estimated/derived, selected by the model, or calibrated (x).....

Table 2.2: Geomorphic data for the six streambank study sites used to calibrate and test BSTEM at Horseshoe Run, WV.

Table 2.3: BSTEM was run iteratively where the input elevation and duration of flow were changed with each iteration to model the entire study period. Stage data from the upstream gage were discretized into various duration intervals. Each simulation (A-F) represents a unique series of duration intervals and total number of model iterations. Summary of dates, durations, and total number of model iterations for each of the hydrograph discretization simulations are listed below. Minimum and maximum durations for each simulation are outlined. 22 iterations were run to generate predicted erosion for simulation A where the minimum flow duration was 24 hours and the maximum was 1,767 hours. 685 iterations were run to generate predicted erosion for simulation $\mathrm{F}$ where the minimum flow duration was 1 hour and the maximum was 1,767 hours. Simulation D was found to be the most efficient series of duration intervals and model iterations for sites 9 and 21. These flow duration intervals and corresponding streamflow elevation data were used to model erosion at the other four sites.

Table 2.4: Bank and toe material values provided in BSTEM are listed in the upper half of the table and weighted average values of these same parameters based on the laboratory determined

soil textural classification are listed in the lower half of the table.

Table 2.5: Vegetation summary data for sites 1, 9, and 11 used as input to RipRoot and associated RipRoot cohesion output values. Percentages of each type of vegetation is used as input in combination with either root tensile strength coefficients ( $a$ and $b$ where root tensile strength $=\mathrm{aD}^{\mathrm{b}}$ and $\mathrm{D}$ is the number of roots per diameter size class) or age. $\sim$ indicates that age was used with percentages. NA indicates that age was not used. Root tensile strength coefficients for Rosa multiflora were determined by averaging those coefficients in the model for the Rosaceae family. Root tensile strength coefficients for Aesculus flava were determined by averaging those coefficients in the model for all tree species.

Table 2.6: Seven simulations were run for site 9. In simulations 1-3, the vegetative cohesion values were altered based on the RipRoot predicted cohesion, the apparent cohesion (Wu 1979) and no added cohesion from roots. Simulations 4-5 were run with the default bank and toe model parameters for gravel and clay since the bank material at the site ranged from gravel size to clay size material. Simulations 6-7 represented conditions where the water table in the streambank was set to the elevation of the previous iteration to represent bank storage conditions. The water table elevation was set equal to the stream flow elevation for each iteration for all other model results. Since $\mathrm{F}_{\mathrm{s}}$ was not less than 1 for Simulation 2 and 5, due to the added cohesion of roots and clay respectively, these can be eliminated as potentially improved simulations. Simulations 3 and 4 can be eliminated because the model unrealistically predicted mass failure prior to any flow due to the lack of cohesion by roots and gravel respectively, and this cannot be the case because the bank was stable during initial data collection. Simulation 6 
was run so that the flow elevation from the previous iteration was input as the new groundwater elevation for the next iteration during flow events. This scenario increased the weight of the bank above the streamflow because of the sustained pore water and eliminated the confining pressure created by the streamflow so that the pore water pressure in the bank was not counter pressured by the streamflow. The model was calibrated with this scenario for site 9 as well. ... 58

Table 2.7: Parameters used as input to test the model prediction capabilities at four additional sites with prediction error.

Table 3.1: BANCS model input parameters with associated measurement units. X's indicate whether the parameter was measured based on data collected in the field or estimated/derived using best professional judgement. Minimum, mean, and maximum values for the upper and lower reach are also provided for each parameter.

Table 3.2: MANOVA results indicating that cross sectional area, cross sectional width, median particle size (D50) and radius of curvature are significantly different between the upper and lower reach

Table 3.3: PCA results with principle components with eigen values greater than $>1$. Only those variable loadings $>|0.4|$ are shown. PC1 is controlled by bank angle, bank material, and stratification. PC2 is controlled by the vegetation parameters. PC3 is controlled by surface protection and near bank depth ratios.

Table 3.4: Regression models for the upper and lower reaches. Parsimonious models, described by the lowest number of parameters with a multiple $r^{2}$ value $>0.8$ was selected from the subset of all models for each reach. 106

Table 4.1: BSTEM and BANCS model parameters by category 108 


\section{List of Figures}

Figure 2.1: Horseshoe Run watershed and project vicinity within the Allegheny Mountain Section of the Appalachian Plateau Physiographic Province, West Virginia.

Figure 2.2: Streambank sites used for calibrating and testing BSTEM. Streamflow is from left to right. (2006 LiDAR digital elevation model and aerial photo maps provided by Canaan Valley Institute).

Figure 2.3: Averaged precipitation from the Davis 3SE and Parsons 1NE National Climate Data Center weather stations and streamflow stage from the Canaan Valley Institute streamgage for the study period. Solid horizontal line represents the stage required for flow to overtop banks for the average bank height through the study area. Lower dotted line represents the stage required to overtop the shortest study bank while upper dotted line represents the stage required to overtop the tallest study bank. Gaps in streamflow represent missing data. 52

Figure 2.4: BSTEM was run iteratively where the input elevation and duration of flow were changed with each iteration to model the entire study period. Stage data from the upstream gage were discretized into various duration intervals. Each simulation (A-F) represents a unique series of duration intervals and total number of model iterations. 22 iterations were run to generate predicted erosion for simulation A where the minimum flow duration was 24 hours and the maximum was 1,767 hours. 685 iterations were run to generate predicted erosion for simulation $\mathrm{F}$ where the minimum flow duration was 1 hour and the maximum was 1,767 hours. Simulation D was found to be the most efficient series of duration intervals and model iterations for sites 9 and 21. These flow duration intervals and corresponding streamflow elevation data were used to model erosion at the other four sites.

Figure 2.5: BSTEM was run iteratively where the input elevation and duration of flow were changed with each iteration to model erosion for the entire study period. Stage data from the upstream gage were discretized into various duration intervals. Each simulation (A-F) represents a unique series of duration intervals and total number of model iterations. Bars below represent the predicted erosion for each simulation and the measured erosion at these two sites. Simulation $\mathrm{D}$ was found to be the most efficient series of duration intervals and model iterations for sites 9 and 21. These flow duration intervals and corresponding streamflow elevation data were used to model erosion at the other four sites.

Figure 2.6: BSTEM predicted erosion as a function of the particle diameter used to infer critical shear stress for sites 19,21 and 22. A number of simulations (solid symbols) were run for each streambank site altering only the critical shear stress which was determined from the noncohesive particle diameter and the Shields curve and Lane adjustment. The actual measured erosion for each site is identified on the curve with squares.

Figure 2.7: Cumulative percent graph of the 20 particle diameters measured along the bank profile for sites 19,21, and 22. The non-cohesive particle diameters corresponding to the actual erosion amount from Figure 2.6 are also included in the graph with squares. 
Figure 2.8: Particle diameter distribution from the pebble counts for sites 19, 21, and 22. Site 22 has a slightly bimodal distribution with a peak in the very coarse gravel range and a peak in the small cobble range.

Figure 2.9: The bank profile overlays for site 11 indicate that the majority of erosion occurred in the upper bank layers. 63

Figure 2.10: A plot of the observed versus BSTEM predicted erosion indicated that the model accurately predicted relative amounts of erosion with only one exception, site 22 . Squares are calibrated sites, circles are test sites. A 1:1 line is depicted on the diagonal. Site 22 had the third highest observed erosion but the second lowest BSTEM predicted erosion. This difference is likely due to the local variation in shear stress.

Figure 3.1: The study area is located near the outlet of the Horseshoe Run watershed which lies within the Allegheny Mountain Section of the Appalachian Plataea physiographic province, Tucker County, WV.

Figure 3.2: Averaged precipitation from the Davis 3SE and Parsons 1NE National Climate Data Center weather stations and streamflow stage from the Canaan Valley Institute streamgage for the study period. Solid horizontal line represents the stage required for flow to overtop banks for the average bank height through the study area. Lower dotted line represents the stage required to overtop the shortest study bank while upper dotted line represents the stage required to overtop the tallest study bank. Gaps in streamflow represent missing data.

Figure 3.3: Barplot of measured erosion $\left(\mathrm{m}^{2}\right)$ at the streambank sites in order from upstream to downstream. .

Figure 3.4: Boxplots of statistically significant parameters for the lower and upper reaches as determined by the MANOVA: (A) Log of Cross sectional Area (B) Log of Cross sectional width (C) Log of D50 (D) Radius of curvature.

Figure 3.5: Scatterplot of streambank characteristic principle component scores 1 and 2 where observations are coded by location: upper reach (Up) or lower reach (Low). Separation between the upper and lower reach is evident on the PC1 axis controlled by bank angle, bank material, and stratification. Separation within the upper reach sites is evident on PC2 controlled by the vegetation parameters.

Figure 3.6: Cluster analysis using the ward agglomeration method identified three groups of streambanks. Boxplots of $\log ($ erosion) values indicate that Group 3 had lower erosion amounts than the remaining streambank sites. Streambanks in Group 3 were characterized by low bank angles, some surface protection, and intermediate rooting depth and density values. 103

Figure 3.7: All-possible-subset regression was used to identify the subset of BANCS model parameters that could best predict erosion. The best model determined for each subset size in the all subset regression analysis for the upper reach is represented on the left. Bank angle had the 
highest correlation with erosion when each parameter was correlated with erosion separately, explaining $58 \%$ of the variation in erosion $\left(\mathrm{R}^{2}\right)$. The best model for each pair of parameters included bank angle and bank material adjustment, explaining $66 \%$ of the variation in erosion. The model including bank angle, bank material adjustment, near bank stress, and the vegetation parameters was selected as the most parsimonious. Relative importance metric plots were plotted for this model. Relative importance measures were calculated using the following methods: average sequential sums of squares over all orderings of regressors, Lindeman, Merenda, and Gold method (lmg) (Lindeman et al. 1980); comparison of what each regressor was able to explain in addition to all other variables (last); comparison of each regressor alone (first); and comparison of the importance to a variable in proportion to the product of its standardized regression coefficient (Pratt 1987). These metrics all indicate that bank angle was the most important variable. * indicates the parameter was log base 10 transformed.

Figure 3.8: All-possible-subset regression was used to identify the subset of BANCS model parameters that could best predict erosion. The best model determined for each subset size in the all subset regression analysis for the lower reach is represented on the left. Bank angle had the highest correlation with erosion when each parameter was correlated with erosion separately, explaining $28 \%$ of the variation in erosion $\left(\mathrm{R}^{2}\right)$. The best model for each pair of parameters included bank angle and surface protection, explaining $56 \%$ of the variation in erosion. The model including bank angle, the vegetation parameters, and bank height ration was selected as the most parsimonious. Relative importance metric plots were plotted for this model. Relative importance measures were calculated using the following methods: average sequential sums of squares over all orderings of regressors, Lindeman, Merenda, and Gold method (lmg) (Lindeman et al. 1980); comparison of what each regressor was able to explain in addition to all other variables (last); comparison of each regressor alone (first); and comparison of the importance to a variable in proportion to the product of its standardized regression coefficient (Pratt 1987). With the exception of the last method, these metrics indicate that bank angle was the most important variable followed by weighted root density. * indicates the parameter was log base 10 transformed. 


\section{Introduction}

\subsection{Introduction}

Erosion and deposition are natural weathering processes that have been shaping the environment for millennia. By altering the landscape and interfering with the natural movement of water through catchments, humans have accelerated these processes. As a consequence, an increasing number of aquatic ecosystems are impaired by sediment. The Clean Water Act aims to identify and correct water quality impairments, including those due to sediment, although the methods to perform this task for sediment are not clearly defined in the law. The scope of sediment problems is not limited to the Clean Water Act, as groups such as Trout Unlimited, the Chesapeake Bay Trust Foundation, and many state and federal wildlife agencies have made sediment management a high priority.

Historically, sediment was thought to originate largely from surface runoff and overland flow. Over the past several decades, sediment originating from streambanks has been realized as a potentially greater source to streams (Evans et al. 2006; Prosser et al. 2000; Simon and Rinaldi 2006). However, predictive models for estimating sediment have not caught up with this shift in our understanding of sediment dynamics. This may be due to the complexity associated with streambank erosion across scales. Until erosion at the local scale is better understood, the ability to develop predictive models will be limited. This study looked at the interaction of a number of factors and processes that influenced streambank erosion along a $1.5 \mathrm{~km}$ reach of Horseshoe Run in Tucker County, West Virginia. 


\section{Streambank erosion}

Streambanks erode through a combination of processes including streambank weakening, failure of bank materials due to gravity, and detachment of bank materials due to flow (Lawler et al. 1997). The influence of each mechanism on total streambank erosion varies by stream and may vary both spatially and temporally within a single reach. Cohesive streambanks with high silt and clay contents are typically more susceptible to weakening by subaerial processes (Couper 2003), and in some cases the subaerial weakening may be the dominant cause of erosion. Three

primary subaerial processes are responsible for streambank weakening: pre-wetting, desiccation, and freeze-thaw cycling (Wynn et al. 2008).

\section{Subaerial processes}

Pre-wetting can occur either due to groundwater rise or from infiltration from the surface. Subsurface flow through the cohesive streambank can lead to seepage erosion or piping erosion if the flow is through macropores exposed in the bank face (Fox et al. 2007). A pre-wetted bank can also indirectly increase the susceptibility to erosion by altering soil properties such as shear strength and cohesion (Fox and Wilson 2010; Simon et al. 2000). Furthermore, when a wetted bank dries, or during periods of prolonged desiccation, vulnerability due to cracking is introduced (Langendoen et al. 2009). Freeze and thaw cycles may open cracks in the bank and increase erosion as well (Shields et al. 2009). In a recent study, $80 \%$ of the variation in erodibility was explained by freeze-thaw cycling in a Southwestern Virginia streambank (Wynn et al. 2008). 


\section{Mass/gravitational failure}

Streambank weakening may make the bank more susceptible to bank failure due to gravity. Mass failure of streambanks is primarily controlled by the height and slope of the bank, the geotechnical and hydrologic properties of the bank, and the weight and position of bank objects such as trees (Abernathy and Rutherford 2000; Simon and Collison 2002). Tall, steep or overhanging banks have more gravitational forces acting on them and therefore are more susceptible to failure. While the geometric factors are straightforward, the remainder of the controlling factors are more complicated. Physical soil properties, soil moisture, and vegetation are interdependent factors that contribute to the overall resistance of a streambank to gravitational failure.

Many studies have reported on the importance of silt and clay content with respect to the failure of streambanks (Julian and Torres 2006; Thorne 1982; Vanoni 1977). In addition to soil texture, Hanson and Simon (2001) found clay mineralogy, soil structure, and organic content were influential, while Wynn and Mostaghimi (2006) identified soil pH, salt concentration, and bulk density as important factors. Because wet soils are more susceptible to mass wasting than dry soils, soil moisture is a significant factor that influences erosion susceptibility (Abernathy and Rutherfurd 1998; Simon et al. 2000). Soil moisture is spatially and temporally dependent, thus making generalizations about the role of soil moisture in streambanks difficult (Pollen 2007).

Vegetation affects both soil moisture and the shear strength of soils. Soil is strong in compression and weak in tension, while roots are strong in tension and weak in compression; the combination thereby enhances the stability of the streambank (Simon and Collison 2002).

Estimating the effects of vegetation is time consuming and a number of estimation techniques 
have been studied without widespread agreement on which method provides the most accurate results (Abernathy and Rutherford 2000; Easson and Yarbrough 2002; Micheli and Kirchner 2002; Piercy and Wynn 2008; Pollen-Bankhead and Simon 2009). Agreement on which types and species of vegetation is most effective at increasing bank stability is also lacking (Abernathy and Rutherford 2001; Pollen-Bankhead and Simon 2009; Simon and Collison 2002; Wynn and Mostaghimi 2006). Vegetation implications on streambank erosion are further complicated by its potential destabilizing effects. The weight of trees for example increases the susceptibility of erosion by gravitational failure and the interaction between vegetation that impedes in-stream flow may accelerate avulsions, bank attack, and secondary channel formation (Simon and Collison 2002; Wallick et al. 2006).

\section{Fluvial erosion}

Fluvial or hydraulic erosion is a function of the forces of flowing water against the streambed and banks. If forces imparted by flowing water are great enough to mobilize bed and bank material, the stream channel will be reshaped. When the boundary shear stress exceeds the critical shear stress, mobilization of grains is expected; however, secondary currents, the location within a meander bend, flow duration, the number of discharge peaks, and other factors have been found to influence this excess shear stress relationship (Julian and Torres 2006; Papanicolaou et al. 2007; Wallick et al. 2006). More research is needed to quantify the process of fluvial erosion, especially since in some cases fluvial erosion may account for more than $85 \%$ of all streambank erosion at a site (Luppi et al. 2008; Pizzuto 2009). 


\section{Erosion prediction models}

Attempts have been made to generate models that predict streambank erosion. Models can be classified as either mechanistic or empirical (Pizzuto 2009). Mechanistic models tend to rely on the Mohr-Coulomb failure criterion with varying modifications for cohesion due to roots for mass failure and an excess critical shear stress approach for fluvial erosion (Abernathy and Rutherford 2000; Coffman 2009; Donald and Zhao 1995; Easson and Yarbrough 2002; Pollen 2007; Pollen-Bankhead and Simon 2009; Waldron and Dakessian 1981; Wu et al. 1979). Empirical models often include a much broader range of variables that either directly or indirectly represent the mechanistic variables. Some common variables that have been used to successfully predict erosion in empirical models include freeze thaw cycling (Pizzuto 2009; Wynn and Mostaghimi 2006), soil bulk density (Wynn and Mostaghimi 2006), near bank velocities (Pizzuto 2009), cross sectional dimensions (Chen et al. 2005; Magner and Brooks 2008), flow conditions (e.g. duration, peak) (Julian and Torres 2006), silt clay content (Julian and Torres 2006), and various vegetation indices (Chen et al. 2005; Julian and Torres 2006; Magner and Brooks 2008; Pizzuto 2009; Rosgen 2001; Rosgen 2006; Wynn and Mostaghimi 2006). Many of these models have been successfully tested at individual sites; however, there is a need to generate a model with regional applications that can be transferred across sites.

A mechanistic and an empirical model were chosen for this study based on their potential transferability; the Bank Stability and Toe Erosion Model (BSTEM) (Simon et al. last modified 9/11/2009) and the Bank Assessment of Non-point Source Consequences of Sediment model (BANCS) (Rosgen 2006). The objective of this study was to evaluate the effectiveness of these two streambank erosion models, using available data and/or data that could be reasonably collected within the financial and time constraints of a typical watershed planning or restoration 
project. The models were tested on streambank reaches along Horseshoe Run in Tucker County, West Virginia where streambanks have been actively eroding over the past decade (Canaan Valley Institute 2006; SAMB 2003, USGS 1997). The lower third of the study reach was recently restored as part of a larger watershed restoration effort.

\subsection{Chapter descriptions}

The research described in the following chapters explored the applicability of two existing erosion models at predicting erosion in an actively eroding and recently restored stream reach. Results from this study help identify gaps in the models and evaluate the models' respective utility to on-the-ground stream prioritization and restoration efforts.

Chapter 2 investigates the mechanistic streambank erosion prediction model BSTEM. The model has a lot of potential as an erosion prediction tool by incorporating a number of factors and processes. The general objectives of this chapter were to explore the model sensitivity, to determine if the model can be calibrated without collecting extensive field data, and to test the transferability of calibrated parameters to additional streambanks by comparing model predictions to observed erosion.

Chapter 3 explores the model parameters included in the empirical BANCS model. Versions of this model have been widely adopted by state and federal agencies as a tool to prioritize restoration projects and to monitor the success of these projects once implemented. We explore the appropriateness of using this model to estimate erosion at actively eroding and restored sites. The objectives of this chapter were to determine if the parameters included in the model could be used to predict erosion and to explore whether the differing stream morphologies 
and streambank characteristics in the actively eroding and restored stream reaches has implications for streambank erosion processes and predictions.

The concluding chapter summarizes the results from the study and discusses potentially useful way forward in which the two modeling methods can be used to inform each other and advance our understanding of streambank erosion. Summary data and additional data not included explicitly in either chapter are listed in the Appendices at the end of this manuscript. 


\section{Literature Cited}

Abernathy, B., and Rutherford, I. (2000). "The effect of riparian tree on the mass-stability of riverbanks." Earth Surface Processes and Landforms, 25, 921-937.

Abernathy, B., and Rutherford, I. (2001). "The distribution and strength of riparian tree roots in relation to riverbank reinforcement." Hydrological Processes, 15, 63-79.

Abernathy, B., and Rutherfurd, I. (1998). "Where along a river's length will vegetation most effectively stabilise stream banks?" Geomorphology, 23, 55-75.

Chen, Y., Bhatia, S. K., Buchanan, J., DeKoskie, D., and VanSchaack, R. (2005). "Effectiveness of Stream Restoration in Reducing Stream Bank Erosion: The Case of Batavia Kill Stream Restoration Projects, New York."

Coffman, D. K. (2009). "Streambank erosion assessment in non-cohesive channels using erosion pins and submerged jet testing, Dallas/Fort Worth, Texas," Master of Science, Baylor University.

Couper, P. (2003). "Effects of silt-clay content on the susceptibility of river banks to subaerial erosion." Geomorphology, 56, 95-108. 
Donald, I. B., and Zhao, T. (1995). "GWEDGEM: A computerprogram for slope stability analysis based on the generalised wedge method. User's Manual." Department of Civil Engineering, Monash University, Melbourne.

Easson, G., and Yarbrough, L. (2002). "The effects of riparian vegetation on bank stability." Environmental and Engineering Geoscience, VIII(4), 247-260.

Evans, D. J., Gibson, C. E., and Rossell, R. S. (2006). "Sediment loads and sources in heavily modified Irish catchments: A move towards informed management strategies." Geomorphology, 79, 93-113.

Fox, G. A., Chu-Agor, M. L., and Wilson, G. V. (2007). "Erosion of noncohesive sediment by ground water seepage: Lysimeter experiments and stability modeling." Soil Science Society of America Journal, 71(6), 1822-1830.

Fox, G. A., and Wilson, G. V. (2010). "The role of subsurface flow in hillslope and streambank erosion: A review." Soil Science Society of America Journal, 74, 717-713.

Hanson, G. J., and Simon, A. (2001). "Erodibility of cohesive streambeds in the loess area of the midwestern USA." Hydrologic Processes, 15, 23-38.

Julian, J. P., and Torres, R. (2006). "Hydraulic erosion of cohesive riverbanks." Geomorphology, $76,193-206$. 
Langendoen, E. J., Lowrance, R. R., and Simon, A. (2009). "Assessing the impact of riparian processes on streambank stability." Ecohydrology, 2, 360-369.

Lawler, D. M., Thorne, C. R., and Hooke, J. M. (1997). "Bank erosion and instability." Applied Fluvial Geomorphology for River Engineering and Management, C. R. Thorne, R. D. Hey, and M. D. Newsom, eds., John Wiley \& Sons Ltd, West Sussex, England.

Luppi, L., Rinaldi, M., Teruggi, L. B., Darby, S. E., and Nardi, L. (2008). "Monitoring and numerical modelling of riverbank erosion processes: a case study along the Cecina River (central Italy)." Earth Surface Processes and Landforms.

Magner, J. A., and Brooks, K. N. (2008). "Predicting stream channel erosion in the lacustrine core of the upper Nemadji River, Minnesota (USA) using stream geomorphology metrics." Environmental Geology, 54, 1423-1434.

Micheli, E. R., and Kirchner, J. W. (2002). "Effects of wet meadow riparian vegetation on streambank erosion. 2. Measurements of vegetated bank strength and consequences for failure mechanics." Earth Surface Processes and Landforms, 27, 687-697.

Papanicolaou, A. N., Elhakeem, M., and Hilldale, R. (2007). "Secondary current effects on cohesive river bank erosion." Water Resources Research, 43, W12418.

Piercy, C., and Wynn, T. (2008). "Predicting root density in streambanks." Journal of the American Water Resources Association, 44(2), 496-508. 
Pizzuto, J. (2009). "An empirical model of event scale cohesive bank profile evolution." Earth Surface Processes and Landforms, 34, 1234-1244.

Pollen, N. (2007). "Temporal and spatial variability in root reinforcement of streambanks: Accounting for soil shear stength and moisture." Catena, 69, 197-205.

Pollen-Bankhead, N., and Simon, A. (2009). "Enhanced application of root-reinforcement algorithms for bank-stability modeling." Earth Surface Processes and Landforms, 34, 471-480.

Prosser, I. P., Hughes, A. O., and Rutherford, I. D. (2000). "Bank erosion of an incised upland channel by subaerial processes: Tasmania, Australia." Earth Surface Processes and Landforms, 25, 1058-1101.

Rosgen, D. "A practical method of computing streambank erosion rate." Proceeding of the seventh Federal Interagency Sedimentation Conference, Reno, NV, II-9-II-15.

Rosgen, D. (2006). Watershed Assessment of River Stability and Sediment Supply (WARSSS), Wildland Hydrology, Fort Collins, CO.

Shields, F. D., Jr, Simon, A., and Dabney, S. M. (2009). "Streambank dewatering for increased stability." Hydrologic Processes, 23, 1537-1547. 
Simon, A., and Collison, A. (2002). "Quantifying the mechanical and hydrologic effects of riparian vegetation on streambank stability." Earth Surface Processes and Landforms, 27, 527-546.

Simon, A., Curini, A., Darby, S., and Langendoen, E. (2000). "Bank and near-bank procsses in an incised channel." Geomorphology, 35, 193-217.

Simon, A., and Rinaldi, M. (2006). "Disturbance, stream incision, and channel evolution: The roles of excess transport capacity and boundary materials in controlling channel response." Geomorphology, 79(3-4), 361-383.

Simon, A., Thomas, R., Curini, A., and Bankhead, N. (last modified 9/11/2009). "Bank-Stability and Toe-Erosion Model Static Version 5.2." USDA-ARS National Sedimentation Laboratory Oxford, MS.

Thorne, C. R. (1982). "Processes and mechanisms of river bank erosion." Gravel-bed rivers, R. D. Hey, J. C. Bathurst, and C. R. THorne, eds., Wiley, Chichester, 227-259.

Vanoni, V. A. (1977). "Sedimentation Engineering." ASCE, New York, 745.

Waldron, L. J., and Dakessian, S. (1981). "Soil reinforcement by roots: calculation of increased soil shear resistence from root properties." Soil Science, 132, 427-435. 
Wallick, J. R., Lancaster, S. T., and Bolte, J. P. (2006). "Determination of bank erodibility for natural and anthropogenic bank materials using a model of lateral migration and observed erosion along the Willamette River, Oregon, USA." River Research and Applications, 22, 631-649.

Wu, T. H., III, W. P. M., and Swanson, D. N. (1979). "Strength of tree roots and landsclides on Prince of Wales Island, Alaska." Canadian Geotechnical Journal, 16(1), 19-33.

Wynn, T., and Mostaghimi, S. (2006). "The effects of vegetation and soil type on streambank erosion, southwestern Virginia, USA." Journal of the American Water Resources Association, 42(1), 69-82.

Wynn, T. M., Henderson, M. B., and Vaughan, D. H. (2008). "Changes in streambank erodibility and critical shear stress due to subaerial processes along a headwater stream, southwestern Virginia, USA." Geomorphology, 97, 260-273. 


\section{The calibration and testing of the physically-based streambank erosion model BSTEM at \\ Horseshoe Run, Tucker County, West Virginia}

\subsection{Abstract}

The Bank Stability and Toe Erosion Model could be used cautiously as a relative indicator of erosion without collecting extensive field data. Modeling the first three largest peak flows with 6 hour durations and the smaller stormflows with 12 hour durations had the greatest efficiency for predicting annual erosion. We found the model was sensitive to critical shear stress and that critical shear stress values for gravel and cobble should be calibrated based on the size of the non-cohesive particles on the streambed and banks rather than using the cited values. Our results suggested that minimum pebble count values or those in the lower 10 percentile may provide more accurate erosion prediction results than the D50 when converting particle size to critical shear stress using the Shields curve. The predictive ability of the model was improved by using weighted averages of those values included in the model for friction angle, cohesion, saturated unit weight, critical shear stress and erodibility for the different soil texture classes. Using cohesion values predicted by the root reinforcement submodel also improved the model performance. Model validation revealed critical shear stress of the bed material to be locally specific and non transferable to neighboring sites on the same stream. Though BSTEM underpredicted erosion by between 60 and 75\%, the model was able to provide relative estimates of eroded material and was also able to predict the type of erosion present at each bank site. Relative amounts of erosion are often used to prioritize stream restoration projects; thus this model could aid in the estimation of relative sediment contributions. Because the model also predicted the type of erosion, potential restoration strategies could be identified and restoration alternatives or scenarios could be modeled to determine if these scenarios may facilitate the reduction of erosion. 


\subsection{Introduction}

Streambank erosion is the leading contributor of sediment to streams all over the world (Evans et al. 2006; Lawler et al. 1999; Prosser et al. 2000; Rosgen 1973; Rosgen 1976; Sekely et al. 2002; Simon et al. 2006; Simon and Rinaldi 2006; Trimble 1997) and billions of dollars are spent trying to slow or arrest the erosion of streambanks and protect our aquatic resources from sediment impairment (Moerke et al. 2004; Palmer et al. 2005). Predictive models of streambank erosion could help not only to identify streambanks that are large contributors of sediment but also help to inform bank stabilization strategies to slow erosion (Pollen-Bankhead and Simon 2009). Development of predictive models is complicated as it integrates a number of factors and processes that are not yet fully understood. Substantial progress, however, is being made to advance our understanding of the influence of various soil properties (Clark and Wynn 2007; Hanson and Simon 2001; Pollen 2007; Wynn and Mostaghimi 2006), vegetative cohesion properties (Abernathy and Rutherford 2001; Micheli and Kirchner 2002; Piercy and Wynn 2008; Pollen-Bankhead and Simon 2008; Pollen-Bankhead et al. 2009a; Simon and Collison 2002), groundwater (Fox et al. 2007; Fox and Wilson 2010; Langendoen et al. 2009; Magner and Brooks 2008; Simon et al. 2000), and streamflow mechanics (Julian and Torres 2006; Papanicolaou et al. 2007; Wallick et al. 2006) on streambank erosion. Recently, mechanistic streambank models have been developed that incorporate this emerging research (Darby et al. 2007; Pollen-Bankhead and Simon 2009; Simon et al. 2003; Simon and Rinaldi 2006), but studies addressing the calibration and testing of these models is rare (Rinaldi et al. 2008; Simon et al. 2009). The potential use of these models to help prioritize streambank erosion sites and inform stabilization efforts is just starting to be explored. 


\subsubsection{BSTEM description}

BSTEM is a physically-based model that incorporates both the shear failure of a streambank and the erosion of bank material by flow (Simon et al. last modified 9/11/2009). BSTEM combines two submodels to predict erosion. We predicted annual erosion by running the model with water surface elevations and durations from November 2009 to October 2010.

\subsubsection{Toe erosion submodel}

The toe erosion submodel uses an excess shear stress approach to predict erosion by hydraulic forces, whereby if the hydraulic forces exerted by the flowing water are greater than the resisting forces of the bed and bank material, the material will be eroded. Hydraulic forces are calculated as the mean boundary shear stress:

$$
\left.\tau_{o}=\gamma_{w} R S_{w} \text { (eq. } 1\right)
$$

where $\tau_{\mathrm{o}}=$ mean boundary shear stress $\left(\mathrm{N} / \mathrm{m}^{2}\right), \gamma_{\mathrm{w}}=$ unit weight of water $\left(\mathrm{N} / \mathrm{m}^{3}\right), \mathrm{R}=$ hydraulic radius $(\mathrm{m})$, and $\mathrm{S}_{\mathrm{w}}=$ water-surface slope. A Shields-type critical shear stress $\tau_{\mathrm{c}}$ is used to represent the resisting forces of the bank and bank toe material. The model accounts for the inclination of the bank by incorporating a side slope adjustment factor (Lane 1953);

$$
\left.\tau_{c b}^{*}=\tau_{c r} * \cos \varepsilon \sqrt{1-\left(\tan ^{2} \varepsilon / \mu^{2}\right)} \text { (eq. } 2\right)
$$

where $\tau_{\mathrm{cb}} *=$ dimensionless critical shear stress on the side slope, $\tau_{\mathrm{cr}} *$ is obtained from Shieldstype entrainment curve, $\varepsilon=$ side-slope angle of the bank, $\mu=$ Coulomb coefficient of friction based on the assumption that it is equivalent to the tangent of the friction angle of the sediment (Bagnold 1953; Bagnold 1966; Francis 1973). The adjustment factor is then incorporated into the critical shear stress equation:

$$
\left.\tau_{c}=\tau_{c b} *\left(\left(\rho_{s}-\rho\right) g D\right) \quad \text { (eq. } 3\right)
$$


where $\rho_{\mathrm{s}}=$ sediment density $\left(\mathrm{kg} / \mathrm{m}^{3}\right), \rho=$ fluid density $\left(\mathrm{kg} / \mathrm{m}^{3}\right), \mathrm{g}=$ acceleration due to gravity $\left(\mathrm{m} / \mathrm{s}^{2}\right)$, and $\mathrm{D}=$ representative particle diameter $(\mathrm{m})$.

\subsubsection{Bank stability submodel}

The bank stability submodel relies on a factor of safety approach for calculating stability where the factor of safety $\left(\mathrm{F}_{\mathrm{s}}\right)$ is represented by the ratio between resisting and driving forces of the streambank to failure. If $F_{s}$ is less than 1 , the bank is susceptible to failure. The Mohr-Coulomb equation is the basis for the resisting forces with added resistance based on vegetative cohesion and matric suction:

$$
\left.\tau_{f}=c^{\prime}+\left(\sigma-\mu_{w}\right) \tan \phi^{\prime} \text { (eq. } 4\right)
$$

where $\tau_{f}=$ soil shear strength, $c^{\prime}=$ effective cohesions, $\sigma=$ normal stress, $\mu_{w}=$ pore-water pressure, and $\phi^{\prime}=$ effective angle of internal friction (degrees). Driving forces include bank height, bank angle, the weight of soil and water in the bank, and the weight of vegetation atop the bank.

\subsubsection{RipRoot}

The added resistance of the bank due to vegetative cohesion is estimated using the rootreinforcing submodel, RipRoot, which is built into the bank stability submodel in BSTEM (Pollen-Bankhead and Simon 2009). Historically, root reinforcement of soils was estimated using simple perpendicular models, but these models have been found to inaccurately estimate root reinforcement in riparian areas (Easson and Yarbrough 2002; Pollen 2007). RipRoot (Pollen and Simon 2005) is a fiber bundle model that accounts for the progressive breaking of roots during streambank failure and works under the assumption that the maximum load withstood by the bundle of fibers is less than the sum of each of their individual strengths. 
Additionally, RipRoot accounts for root pullout by considering root, soil, and moisture information collectively. RipRoot has two input options. The tensile strength of roots as a function of root diameter is the foundation of the submodel:

$$
T_{r}=a D^{b} \quad \text { (eq. 5) }
$$

where $T_{r}$ is the root tensile strength, $D$ is the root diameter, and $a$ and $b$ are species or individual tree specific coefficients. The number of roots in each of seven diameter size classes and the species specific coefficients can be entered or a set of Chapman-Richards regression equations relating root information to tree age can be used to calculate the number of roots. Based on the riparian species and the age of the species, the average number of roots in various size classes can be calculated:

$$
y=a\left(1-e^{-b x}\right)^{c} \quad \text { (eq. 6) }
$$

where $y=$ the average number of roots, $\mathrm{x}=$ tree age (yrs) and coefficients $\mathrm{a}, \mathrm{b}$, and $\mathrm{c}$ are species specific coefficients coded into the model (Pollen-Bankhead and Simon 2009).

\subsubsection{Factor of safety}

The equation used to predict $\mathrm{F}_{\mathrm{s}}$ depends on the type of failure. The bank stability submodel has three built-in limit-equilibrium $\mathrm{F}_{\mathrm{s}}$ calculation methods; horizontal layers (Simon and Curini 1998; Simon et al. 2000), vertical slices with tension cracks (Morgenstern and Price 1965), and cantilever failures (Thorne and Tovey 1990). The model selects a method based on the bank geometry and the lowest possible factor of safety. Both the toe erosion and bank stability submodels produce new geometries if erosion occurs during a modeling event. Annual erosion was simulated by iteratively running the model with different flow and duration conditions that spanned the study period. Table 2.1 shows the model parameters. Parameters 
were measured, inferred from field data, defined by the model, or calibrated. The model is expected to produce the most accurate results when detailed field information is collected; however, it is not always feasible to collect this detailed data, in which case the model should be used cautiously as a relative indicator of stability. For a more detailed discussion of the model, see Simon et al. (2009).

\subsubsection{Objectives}

The general research objectives of this study were to (1) explore the sensitivity of the parameters in the Bank Stability and Toe Erosion Model (BSTEM); (2) determine if the model can be calibrated without collecting extensive field data; and (3) to validate the model and determine the applicability of the selected parameter set at additional field sites. To accomplish this, the following modeling steps were taken:

1. A hydrograph discretization simulation was selected to represent the depths and duration of hydraulic forces acting on the streambed and banks throughout the study period

2. The Bank Toe submodel parameters were calibrated at a site where erosion could be attributed to hydraulic forces

3. The Bank Toe and Bank Erosion submodel parameters were calibrated at a site where both hydraulic forces and mass-failure processes were predicted

4. The first set of calibrated parameters was used to test the model at two additional sites where hydraulic forces were dominant and the second set of calibrated parameters was used to test the model at two additional sites where hydraulic forces and mass failure were present 


\subsection{Methods}

\subsubsection{Study Area}

The Horseshoe Run watershed located in the Allegheny Mountain section of the Appalachian Plateau physiographic province in Tucker County, West Virginia, is approximately $137 \mathrm{~km}^{2}$ in size at the project site (Figure 2.1). The project site is $300 \mathrm{~m}$ upstream of the Horseshoe Run confluence with the Cheat River which drains into the Monongahela and then the Ohio River. The Allegheny Mountain section of the province is highly dissected with steep high energy streams flowing into narrow more moderate floodplains. Watershed elevations range from $1115 \mathrm{~m}$ along Backbone Mountain, the eastern ridge of the watershed, to $473 \mathrm{~m}$ near the outlet with an average slope of $46^{\circ}$. The region is characterized by a humid continental climate with average annual rainfall of $1318 \mathrm{~mm}$ and an average annual temperature of $9.7^{\circ} \mathrm{C}$. The resistant Pennsylvanian aged, conglomeritic Pottsville sandstone underlies the ridges and has weathered into bouldery colluvium while a series of strath terraces have been carved into the Devonian aged Chemung shales and fine-grained sandstones along the Horseshoe Run floodplain (Konsoer 2008; Reger 1923). Hillslope movements in the Chemung Group dating back to the Pleistocene or Holocene as well as some isolated smaller more recent movements have been identified in the Horseshoe Run watershed (Konsoer 2008).

The hillslopes and upper portions of the watershed are in various stages of forest stand development due to the historic and current logging in the watershed. Timber harvesting in the watershed dates back to the early 1800's and is still present today. The narrow floodplain contains a combination of land use practices ranging from intensively grazed to rural residential to forested. Due to the steepness of the hillslopes and the narrowness of the valley, most anthropogenic impacts span the floodplain and in some cases border or intersect the stream. 
Roads are threatened by steep streambanks and impeding streamflow, residences are threatened by streamflow that breaches streambanks, and full cattle access to the stream for watering are not uncommon sites in the Horseshoe Run watershed.

A series of aerial photographs reveals that Horseshoe Run has been actively migrating and eroding at significant rates over the past several decades (Canaan Valley Institute 2006; SAMB 2003; USGS 1997). This migration can be attributed to a combination of natural and anthropogenic disturbances. An inherently high bedload and a history of large flooding events combined with the periodic clearing of large swaths of the hillslope and riparian zone for logging, agriculture, and rural development contribute to the erosive nature of the stream.

\subsubsection{Upper reach characterization}

Streambanks in the upper portion of the reach were characterized by a thin layer of cohesive soil in the upper bank overlaying layers of soil mixed with gravel and cobble. Floodplain soils through the reach were classified as Gilpin channery silt loams, Philo silt loams or a mixture of alluvial material of the Fluvaquents-Udifluvents complex (Losche and Beverage 1967). Stream cross sectional area averaged $85 \mathrm{~m}^{2}$ through the upper section with an average width of $83 \mathrm{~m}$ and depth of $1 \mathrm{~m}$. The average slope was $0.0059 \mathrm{~m} / \mathrm{m}$ and the substrate ranged from fine gravel to large cobble with a D50 of very coarse gravel measuring $52 \mathrm{~mm}$. Vegetation along the upper portion ranged from dense stands of Platanus occidentalis (American sycamore) to mowed grasses. Betula nigra (river birch), Aesculus flava (yellow buckeye), Rosa multiflora (multiflora rose), Elaeagnus umbellate (autumn olive), and Verbesina alterniflora (wingstem) were other common species found growing adjacent to the stream through this section. 


\subsubsection{Lower reach characterization}

Restoration measures were recently implemented along the lower portion of the project reach. Restoration efforts were initiated by residents of the Horseshoe Run watershed after a series of floods threatened to destroy infrastructure and wash away private property. The primary goals of the restoration were to restore stream stability by restoring natural stream dimension and profile, enhancing or reestablishing riparian vegetation, and enhancing aquatic and riparian habitat. The stream channel was narrowed and deepened, and low angle streambanks were reconstructed with coarse gravel and cobble. Rock and log j-hooks were installed to redirect water away from the outer streambanks, and the banks were seeded and mulched with a native riparian seed mix. Restored stream cross sectional area averaged $47 \mathrm{~m}^{2}$ through the lower section with an average width of $56 \mathrm{~m}$ and depth of $0.9 \mathrm{~m}$. The average slope was $0.0044 \mathrm{~m} / \mathrm{m}$ and the substrate ranged from fine gravel to large cobble with a D50 of small cobble measuring $66 \mathrm{~mm}$ through the lower portion of the project reach.

\subsubsection{Experimental approach}

\subsubsection{Site selection}

Annual erosion was monitored at twenty four streambank sites along Horseshoe Run, representing a range of conditions. Six of these sites (sites 1, 9, 11, 19, 21, and 22) were selected to simulate erosion using BSTEM (Figure 2.2). Three sites from the lower reach $(19,21$, and 22) were selected for calibration and testing of the toe erosion component of the model for the lower reach. Mass failure was not predicted or observed at these sites so the bank stability submodel was not used. Site 21 had an intermediate amount of erosion and was used to calibrate the toe erosion parameters and a site with more erosion (site 22) and a site with less erosion (site 19) 
were used to validate the parameterized model. Sites in the upper reach experienced both fluvial erosion and mass failure and therefore both the toe erosion and bank stability submodels were used. Three sites from the upper reach (sites 1, 9, and 11) were selected for calibration and testing. Site 9 experienced an intermediate amount of bank loss from fluvial erosion and mass failure and was selected to calibrate the model. Sites 1 and 11 were selected to validate the parameterized model. The six sites were selected to explore the model performance across a variety of streambank conditions.

\subsubsection{Data collection}

Two permanent benchmarks, $45 \mathrm{~cm}$ lengths of $1.3 \mathrm{~cm}$ diameter reinforcing bar, were pounded vertically into the ground along a transect perpendicular to the stream at each site beyond the top of the bank from which bank profiles were aligned and measured. One horizontal benchmark, or bank pin, was installed in each bank profile where cohesive soils were present (Coffman 2009; Thorne 1981; U.S. Environmental Protection Agency 1999). Bank profiles were measured using either a laser level or a laser distance finder. The laser level was used to collect bank data through the restored reach where banks have a low slope angle (Harrelson et al. 1994). The laser distance finder was used to collect bank data through the upper reach where banks are near vertical or overhanging and cannot be profiled using laser level techniques.

Baseline bank profile measurements were collected in November 2009 and again in October 2010 to generate annual erosion estimates at each site (Henderson 2006; Pollen 2007; Pollen-Bankhead and Simon 2008; Prosser et al. 2000; Simon et al. 2000). The x and y bank profile coordinates were imported into ArcMap, a polygon outlining the eroded area was created, and the area of the polygon was calculated (ESRI 1999-2009). Cross section data was collected 
at each site as well as longitudinal profile data from which channel slope, widths, and depths were derived (Harrelson et al. 1994). A series of one dimensional hydraulic simulations using HEC-RAS 4.1.0 was used to simulate water surface elevations at each of the sites for flows throughout the study period (Hydrologic Engineering Center 2010). Two staff plates were located within the study reach and were used to calibrate the water surface elevations simulated by HEC-RAS 4.1.0. Water surface elevations at the staff plates were observed during six stormflow events and correlated with data from an upstream gage installed by Canaan Valley Institute approximately $5 \mathrm{~km}$ upstream of the project site on Horseshoe Run. The gage collected stage height in 15 minute intervals from November 2009 through October 2010. The gage provided the duration of the elevated water surface elevations. Soil samples were collected and texture analysis was performed in the lab to determine percentages of gravel, sand, silt, and clay within each stratified soil layer (ASTM 1988). Modified Wolman pebble counts were performed at each site (Harrelson et al. 1994). A subset of particle size measurements was made at each bank and bank toe where noncohesive material was present in the bank profile. Vegetation was identified to the species level and percent cover of each species was estimated at each site. Trees were cored and rings were counted to estimate the ages of trees with roots contributing to the cohesion of the streambank.

Lacking a weather station in the watershed, precipitation data from the Davis 3SE (National Climatic Data Center (NCDC) Coop_ID 462211) and Parsons 1NE (NCDC Coop_ID 466867) weather stations were averaged to approximate precipitation values for the entire watershed. Averaging values from the upper portion of the watershed represented by the Davis station and the mouth of the watershed represented by the Parsons station provided approximate values for the study reach. The Davis weather station is located approximately $10 \mathrm{~km}$ east of the 
watershed at an elevation of $1162 \mathrm{~m}$ and the Parsons station is located approximately $6.5 \mathrm{~km}$ south of the watershed at an elevation of $557 \mathrm{~m}$.

\subsubsection{Modeling methods}

Annual erosion was simulated by iteratively running the model with different flow and duration conditions that spanned the study period. For each iteration, the toe erosion submodel was run. If erosion was predicted, the submodel generated a new streambank profile. The predicted profile was then used in the bank stability submodel. If the bank stability submodel generated an Fs $<1$, the submodel generated a new streambank profile based on the failure plane. If failure was predicted, the new profile was used for the next iteration. These steps were repeated until every flow event throughout the study period was modeled. A completed series of iterations is referred to as a simulation throughout this paper.

\subsection{Results}

Total precipitation averaged between the two stations was $1240 \mathrm{~mm}$ for the study period with greater than $5 \mathrm{~m}$ of total snowfall. The highest streamflow events occurred between December and April from a combination of rainfall, snowmelt, and rain on snow events (Figure 2.3). Long term data was unavailable for the CVI gage; however, the nearby USGS Cheat River near Parsons, WV (03069500) gaging station has a historic record and indicates that the January 25th high flow event had a recurrence interval of approximately 1.7 years and the March flow event had a recurrence interval of approximately 1.5 years. The December high flow on Horseshoe Run was a localized event and did not have corresponding elevated discharge on the Cheat River. 
Erosion at the six streambank sites ranged from $0.28 \mathrm{~m}^{2}$ to $5.33 \mathrm{~m}^{2}$ with a mean and median of $1.38 \mathrm{~m}^{2}$ and $0.59 \mathrm{~m}^{2}$ respectively. Because data were collected along a cross sectional transect, only two dimensional erosion data was calculated. A third dimension measured along the length of the bank would have been required to generate the volume of erosion. Cross sectional dimensions for the upper sites averaged $94 \mathrm{~m}^{2}$ in area, $90 \mathrm{~m}$ in width, and $1 \mathrm{~m}$ in depth. Cross sectional dimensions for the lower sites averaged $48 \mathrm{~m}^{2}$ in area, $50 \mathrm{~m}$ in width, and $1 \mathrm{~m}$ in depth. Bank dimensions for the upper sites averaged $1.6 \mathrm{~m}$ in height and $0.5 \mathrm{~m}$ in length with an average angle of $79^{\circ}$. Bank dimensions for the lower sites averaged $2.0 \mathrm{~m}$ in height and $8.2 \mathrm{~m}$ in length with an average angle of $17^{\circ}$. The average streambed slope was lower in the upper reach than the lower reach and the pebble counts indicated a D50 of very coarse gravel in the upper reach and small cobble in the lower reach. Stream and streambank geomorphic parameters are listed in Table 2.2.

\subsubsection{Hydrograph discretization}

BSTEM requires an input stream elevation and duration of flow for each iteration. In order to predict erosion over the entire study period, the model was run iteratively where the input elevation and duration of flow were changed with each iteration. These parameters were determined from the discretization of the upstream hydrograph and the modeling of water surface elevations using HECRAS (Hydrologic Engineering Center 2010) through the study reach. Currently, the model is not automated and each iteration must be manually entered and run. To reduce the total number of iterations required and enable the selection of subsequent calibration parameters, stage data were discretized into individual events of given durations. One hour stream stage data from November 2009 to October 2010 was initially discretized into 
22 discrete events and used as input into BSTEM with individual event durations that ranged from 24 to 1767 hours. Simon et al (2009) used a hydrograph with similar duration events (241767 hours) in their study of mass-failure and sediment load reductions using toe protection and other means. This initial discretization significantly underpredicted erosion at all sites. To increase the model performance, several simulations were run decreasing the time steps and subsequently increasing the maximum streamflow elevations based on a refinement of the hydrograph into more discrete events (Figure 2.4, Table 2.3). Hydrograph discretization simulation $\mathrm{D}$, with event durations ranging from 6 to 1767 hours, was selected as the input hydrograph for further calibration and testing based on the stabilization of the predicted erosion values for sites 9 and 21 at this simulation (Figure 2.5). All other model parameters were held constant for each site to enable comparison between simulations. The duration for the first three peak flows was modeled at 6 hour intervals and the duration for the next two smaller peak flows was modeled at 12 hour intervals. Reducing the duration to 1 hour intervals did not increase the model performance.

\subsubsection{Bank toe submodel calibration}

Using the durations and water surface elevations from simulation $\mathrm{D}$ discussed above, the bank toe submodel was calibrated for site 21 in the lower reach. The bank stability submodel was not used for streambanks in the lower reach because the shallow angles of the streambanks were resistant to gravitational failure. The restored banks in the lower reach were recently reconstructed with non-cohesive, unconsolidated gravel and cobble and therefore critical shear strength and erodibility were assumed to be constant for the entire area of the bank. To calibrate the model, critical shear stress and corresponding erodibility coefficient values were used to 
simulate erosion for the entire study period until the values that minimized the difference between predicted and observed erosion were identified. A critical shear stress value of $37.91 \mathrm{~Pa}$ and corresponding erodibility coefficient of $0.016 \mathrm{~cm}^{3} / \mathrm{Ns}$ predicted an erosion amount of 0.51 $\mathrm{m}^{2}$ at site 21. Measured erosion at the site was $0.50 \mathrm{~m}^{2}$ producing an error of $-2 \%$. These calibrated critical shear stress and erodibility coefficient values were used as input parameters for two nearby streambank sites with similar bank conditions.

\subsubsection{Bank erosion submodel calibration}

Site 9 was chosen for calibration in the upper portion of the reach because it experienced an intermediate amount of erosion; was spatially located in the middle of the reach; had soils typical of the reach; and had an intermediate vegetative cohesion value. Streambanks in this upper portion of the reach were characterized by a thin layer of cohesive soil in the upper bank overlaying layers of various sized gravel and cobble similar to those in the lower reach but with greater amounts of fine material. Banks in this section were subjected to both hydraulic erosion and erosion due to mass failure of the streambank so both BSTEM submodels are important. In addition to the critical shear stress and erodibility coefficients required for the calibration at site 21, the calibration at site 9 involved parameters required by the bank stability model including friction angle, soil cohesion, saturated unit weight, and added cohesion due to vegetation. Initial soil and vegetation parameters were estimated using the percentages of gravel, sand, silt, and clay determined by the texture analysis and the percent cover of the different vegetative species identified in the field in combination with values cited in the model.

Default values for the soil and toe material are listed in the upper portion of Table 2.4. These values were combined with the percentages of gravel, sand, silt, and clay within each layer 
to generate weighted averages. Weighted average values for the two stratified bank layers at site 9 are also listed in Table 2.4 (lower portion). Initial vegetative cohesion values were estimated using the built-in RipRoot, or root-reinforcement model. Betula nigra (river birch) was the only species identified at the streambank sites that was also included in the model at the genus level. Meadow grass values were used for herbaceous and grass species not represented in the model. Because we were unable to age the grasses, we used an age of two years for these species. Two years was the transition from the juvenile to mature growth phase for Alamo switchgrass, which was the growth curve used in the model for meadow grasses, and was thought to represent a conservative age and corresponding root density estimate. Rosa multiflora corresponded with species in the RipRoot model at the family level and so tensile strength-root diameter relation coefficients were averaged for the Rosaceae family and combined with generic numbers of roots per square meter (R. Thomas, personal communication, November 23, 2010). Aesculus flava (yellow buckeye) did not have either a genus or family level counterpart in the model so coefficients of all tree species were averaged for input (Table 2.5).

Because the majority of the bank was characterized by non-cohesive gravels and because mass failure of the bank was directly influenced by the amount of toe erosion, the critical shear stress and erodibility coefficients for the toe material were selected for initial calibration. A critical shear stress value of $20.17 \mathrm{~Pa}$ and corresponding erodibility coefficient of $0.022 \mathrm{~cm}^{3} / \mathrm{Ns}$ predicted an erosion amount of $0.58 \mathrm{~m}^{2}$ at site 9 . Observed erosion at the site was $0.54 \mathrm{~m}^{2}(-6 \%$ error). Once the critical shear stress and erodibility coefficients were identified; vegetative cohesion, bank material, and water table parameters were evaluated to determine if these parameters could improve model results and reduce model error. 
The RipRoot model provided a cohesion value based on a global load-sharing fiberbundle model as well as an apparent cohesion value (Wu et al. 1979). A simulation was run with the predicted apparent cohesion value (Wu 1979) and another simulation was run assuming that vegetation did not contribute to the cohesion of the soil. Simulations were also run with the default bank and toe model parameters for gravel and clay since the bank material at the site ranged from gravel size to clay size material. Default values represented opposite ends of the stress and strength spectrum in the model. The final set of simulations represented conditions where the water table in the streambank was set to the elevation of the previous iteration to represent bank storage conditions. The water table elevation was set equal to the stream flow elevation for each iteration for all other model results. The results from this analysis are presented in Table 2.6.

Five alternative simulations produced errors between 51- 56\% suggesting that a lower critical shear stress value may produce more consistent results; however, a more detailed examination of the predictive sequence for each simulation does not support this. A comparison of the original and remeasured bank profile indicates that both hydraulic erosion and erosion due to mass failure influenced the total erosion at the site. Since $F_{s}$ was not less than 1 for Simulation 2 and 5, due to the added cohesion of roots and clay respectively, these can be eliminated as potentially improved simulations. Simulations 3 and 4 can be eliminated because the model unrealistically predicted mass failure prior to any flow due to the lack of cohesion by roots and gravel respectively, and this cannot be the case because the bank was stable during initial data collection. Simulation 6 was run so that the flow elevation from the previous iteration was input as the new groundwater elevation for the next iteration during flow events. This scenario increased the weight of the bank above the streamflow because of the sustained 
pore water and eliminated the confining pressure created by the streamflow so that the pore water pressure in the bank was not counter pressured by the streamflow. The model was calibrated with this scenario for site 9 as well. With this elevated water table scenario, a critical shear stress of $15.55 \mathrm{~Pa}$ and corresponding erodibility coefficient of $0.025 \mathrm{~cm}^{3} / \mathrm{Ns}$ generated a predicted erosion amount of $0.505 \mathrm{~m}^{2}(7 \%$ error).

\subsubsection{Model prediction at other sites}

Parameters from the two calibrated models were used as input to test the model prediction capabilities at four additional sites (Table 2.7). The critical shear stress and erodibility coefficients identified in model calibration were used as input parameters for site 19, located 125 $\mathrm{m}$ upstream of site 21 , and site 22 , located $104 \mathrm{~m}$ downstream. The model underpredicted erosion at both sites; by $75 \%$ for site 19 and $60 \%$ for site 22 . Two additional sites were tested with the input parameters identified in model calibration at site 9; site 1, located $617 \mathrm{~m}$ upstream of site 9 , and site 11 , located $84 \mathrm{~m}$ downstream. Two scenarios were used to test the model performance at these sites. The first scenario held the water table elevation equal to the elevation of the water in the stream. The second scenario was determined by setting the water table elevation equal to the elevation of the water in the stream during the previous model iteration to represent bank storage conditions. In both scenarios weighted averages of bank material and RipRoot vegetative cohesion values based on bank conditions at each site were used as input since these values at Site 9 generated prediction errors within $10 \%$ of the actual erosion. Using the first set of input parameters, the model underpredicted erosion at site 1 by $68 \%$ and overpredicted erosion at site 11 by $10 \%$. Using the second set of input parameters, the model overpredicted erosion at site 1 by greater than $500 \%$ and overpredicted erosion at site 11 by $10 \%$. 


\subsection{Discussion}

The spatial and temporal variability and process complexity of erosion make mechanistic streambank erosion models difficult to parameterize (Pizzuto 2009). Our results highlighted the difficulty associated with the fluvial entrainment component of mechanistic modeling in gravel bed streams. The unsteady and non-uniform nature of streamflow, the spatial variability of shear stress exerted by flowing water across and along the stream channel, and the proportion of overall shear stress to shear stress acting on individual grains of sediment complicate prediction (Wilcock et al. 2009). The shape of the individual grains, the orientation of the grains, and the degree of packing further add complexity to predicting erosion (Knighton 1998). These confounding factors make calibrating and testing an erosion model difficult for gravel and cobble bed streams.

\subsubsection{Hydrograph discretization}

The toe erosion submodel was sensitive to the discretization intervals of the hydrograph. Erosion at all sites was largely controlled by hydraulic erosion which was calculated using the depth slope formula in the model (eq 1). Hydrograph discretization controls the depth of the water at each time step so getting this close to the actual water surface depths was important. Modeling the first three peak flows with 6 hour durations and the remaining stormflows with 12 hour durations had the greatest efficiency. The majority of erosion for sites 9 and 21 occurred during prolonged stormflow from March $8^{\text {th }}$ to March $23^{\text {rd }}$. The maximum flow for this storm event was predicted to reach or exceed the top of the banks at sites 9 and 21 . By averaging the 
one hour stage into six hour intervals, the peak flow elevation for this event was reduced by only $4 \mathrm{~cm}$.

\subsubsection{Critical shear stress}

The toe erosion submodel was sensitive to the critical shear stress or resistant forces of the bed and bank material, particularly for non-cohesive gravel size material. The default critical shear stresses for gravel and cobble are $11 \mathrm{~Pa}$ and $124 \mathrm{~Pa}$ respectively (Simon et al. last modified 9/11/2009). The corresponding non-cohesive particle diameters for these two stresses are $11 \mathrm{~mm}$ and $128 \mathrm{~mm}$. Model predictions were significantly improved by calibrating the critical shear stress values. When the default gravel values were used at site 21 , the model overpredicted erosion by more than $1,000 \%$ while no erosion was predicted when the default cobble values were used at the same site under the same conditions. Because critical shear stress is directly related to the particle diameter (Shields 1936), we looked at how predicted erosion changed as a function of particle diameter. We generated a series of predicted erosion values using BSTEM for each of the sites in the lower reach, changing only the non-cohesive particle diameter for each prediction in the series. Figure 2.6 shows the relationship between particle diameter and predicted erosion for these three sites. The observed erosion at each of these sites was identified on its respective curve by a square and the associated non-cohesive particle diameters determined by the regression equations for the observed erosion were $30 \mathrm{~mm}$ for site $19,39 \mathrm{~mm}$ for site 21 , and $33 \mathrm{~mm}$ for site 22. Although these particle diameters differed by only millimeters, the difference had major implications for predicted erosion amounts, as indicated by the $76 \%$ and $60 \%$ error in prediction at sites 19 and 22 . 
The differences in predicted erosion also had major implications for the choice of particle diameter to be used in critical shear stress calculations. Modified Wolman pebble counts were performed at each cross section with 20 measurements collected along the banks. The D50 is often used to determine critical shear stress; however, the D50 from the pebble count was in the very coarse gravel to small cobble range which would have led to significantly underpredicting erosion (Figure 2.7). The associated non-cohesive particle diameters from Figure 2.6 were also plotted on the pebble count graph. These diameters suggested that much smaller diameter and associated critical shear stress values would lead to improved predictions than the D50. The distribution of particle sizes indicated a slight bimodal distribution at site 22 with a peak in the very coarse gravel range and another peak in the small cobble range (Figure 2.8). The standard deviation of the grain sizes from the pebble counts was approximately $30 \mathrm{~mm}$ and may be too large for the application of the D50 to be appropriate (Wilcock 1993). Therefore, for gravel and cobble dominated streams with wide variations in size classes, a minimum grain diameter or D10 may be more appropriate to estimate critical shear stress for erosion calculations than the D50. The calibrated critical shear stress was much lower in the upper reach than in the lower reach. This was not surprising since the gravel and cobble toe had a substantial sand component in the upper reach and sand tends to decrease the stress required to mobilize bed and bank material (Curran and Wilcock 2005; Wilcock et al. 2001).

\subsubsection{Bank material and vegetation}

Weighted average values of bank material parameters and the RipRoot cohesion values for vegetation provided realistic estimates of erosion at site 9 after the toe erosion model was calibrated for the critical shear stress and erodibility coefficient values. Using weighted average 
values instead of default parameters included in the bank and toe model improved the model performance. Additionally, the added cohesion due to vegetation as predicted by RipRoot rather than that predicted by $\mathrm{Wu}$ (1979) or than assuming the added cohesion due to vegetation was negligible, improved performance. The extreme difference in model predictions between the two scenarios or sets of input parameters for site 1 was due to differences in the bank stability submodel. The first set of parameters generated a factor of safety value less than one and a bank failure event during only one iteration, whereas the second set of parameters generated factor of safety values less than one and subsequent bank failure events during more than eight iterations. The model appears to predict initial failure but subsequent bank failures using exported bank geometries were not as reliable.

\subsubsection{Model evaluation}

The model appeared to predict erosion fairly well for site 11; however, the location of predicted erosion did not correspond with the actual location of erosion along the bank. The model predicted the majority of erosion occurring on the streambed $\left(0.58 \mathrm{~m}^{2}\right)$ with lesser erosion on the bank toe $\left(0.07 \mathrm{~m}^{2}\right)$ and the bank $\left(0.37 \mathrm{~m}^{2}\right)$. The bank profile overlays indicated that the majority of erosion occurred in the upper bank layers (Figure 2.9). Although it was difficult to determine the exact process responsible for the erosion in the upper part of the bank at site 11 , BSTEM only simulates planar and cantilever failures which may not have been the mechanisms responsible for the loss of material at our site. If the erosion predicted on the streambed was ignored, the model underpredicted erosion by $64 \%$. This error was similar to the error at the other three sites. 
The results from the calibration and test sites indicated that the model could be cautiously used as a relative indicator of streambank stability (Simon et al. last modified 9/11/2009). A plot of the observed versus BSTEM predicted erosion indicated that the model accurately predicted the relative amount of erosion at our sites with only one exception, site 22 (Figure 2.10). Site 22 had the third highest measured amount of erosion, but BSTEM predicted the site to have the fifth highest. This difference can most likely be attributed to the local differences in shear stress between the calibration and validation sites. The model accurately predicted streambank failure at sites 1 and 9 which were confirmed by field data.

\subsection{Conclusion}

The Bank Stability and Toe Erosion Model could be used cautiously as a relative indicator of erosion without collecting extensive field data. Our first objective explored the sensitivity of the model and revealed that the model was sensitive to the depth and duration of streamflow as well as the critical shear stress of the boundary material. Modeling the first three largest peak flows with 6 hour durations and the smaller stormflows with 12 hour durations appeared to improve the model for the least number of iterations. Our results also suggested that the model was sensitive to critical shear stress in mixed gravel and cobble bed streams and that critical shear stress values for gravel and cobble should be calibrated based on the size of the non-cohesive particles on the streambed and banks rather than using the cited values. Our results suggested that minimum pebble count values or those in the lower 10 percentile may provide more accurate erosion prediction results than the D50 when converting particle size to critical shear stress using the Shields curve. 
With regard to our second objective, we determined that the model could be calibrated without collecting extensive field data. The predictive ability of the model was improved by using weighted averages of those values included in the model for friction angle, cohesion, saturated unit weight, critical shear stress and erodibility for the different soil texture classes. Using cohesion values predicted by RipRoot also improved the model performance.

Our third objective of testing the calibrated parameters at additional sites revealed that caution needs to be used in transferring the model parameters to additional sites. The results suggested that critical shear stress of the bed material was locally specific and values could not be assumed for neighboring sites on the same stream. Though BSTEM underpredicted erosion by between 60 and $75 \%$, the model was able to provide relative estimates of eroded material and was also able to predict the type of erosion present at each bank sites. Relative amounts of erosion are often used to prioritize stream restoration projects; thus this model could aid in the estimation of relative sediment contributions. Because the model also predicted the type of erosion, potential restoration strategies could be identified and restoration alternatives or scenarios could be modeled to determine if these scenarios may facilitate the reduction of erosion. 


\section{Literature Cited}

Abernathy, B., and Rutherford, I. (2001). "The distribution and strength of riparian tree roots in relation to riverbank reinforcement." Hydrological Processes, 15, 63-79.

ASTM. (1988). Annual Book of ASTM Standards, American society for testing and materials, Philadelphia.

Bagnold, R. A. (1953). "Experiments on a gravity free dispersion of large solid spheres in a Newtonian fluid under shear." Proc. R. Soc. London., Ser. A, 49-63.

Bagnold, R. A. (1966). "An approach to the sediment transport problem from general physics." U.S. Geological Survey Professional Paper, 422, 1-37.

Clark, L. A., and Wynn, T. M. (2007). "Methods for determining streambank critical shear stress and soil erodibility: Implications for erosion rate predictions." Transactions of the ASABE, 50(1), 95-106.

Coffman, D. K. (2009). "Streambank erosion assessment in non-cohesive channels using erosion pins and submerged jet testing, Dallas/Fort Worth, Texas," Master of Science, Baylor University.

Curran, J. C., and Wilcock, P. R. (2005). "The effect of sand sypply on transport rates in a gravel-bed channel." Journal of Hydraulic Engineering, 131(11). 
Darby, S. E., Rinaldi, M., and Dapporto, S. (2007). "Coupled simulations for fluvial erosion and mass wasting for cohesive river banks." Journal of Geophysical Research, 112.

Easson, G., and Yarbrough, L. (2002). "The effects of riparian vegetation on bank stability." Environmental and Engineering Geoscience, VIII(4), 247-260.

ESRI. (1999-2009). "ArcMap." ArcGIS, Redlands, CA.

Evans, D. J., Gibson, C. E., and Rossell, R. S. (2006). "Sediment loads and sources in heavily modified Irish catchments: A move towards informed management strategies." Geomorphology, 79, 93-113.

Fox, G. A., Chu-Agor, M. L., and Wilson, G. V. (2007). "Erosion of noncohesive sediment by ground water seepage: Lysimeter experiments and stability modeling." Soil Science Society of America Journal, 71(6), 1822-1830.

Fox, G. A., and Wilson, G. V. (2010). "The role of subsurface flow in hillslope and streambank erosion: A review." Soil Science Society of America Journal, 74, 717-713.

Francis, J. R. D. (1973). "Experiments on the motion of solitary grains along the bed of a water stream." Proc. R. Soc. London., 332, 443-471.

Hanson, G. J., and Simon, A. (2001). "Erodibility of cohesive streambeds in the loess area of the midwestern USA." Hydrologic Processes, 15, 23-38. 
Harrelson, C. C., Rawlins, C. L., and Potyondy, J. P. (1994). "Stream Channel Reference Sites: An Illustrated Guide to Field Techniques." RM-245, USDA Forest Service, Rocky Mountain Forest and Range Experiment Station, Fort Collins, CO.

Henderson, M. B. (2006). "Changes in streambank erodibility and critical shear stress due to surface subaerial processes," Master of Science, Virginia Polytechnical Institute and State University, Blacksburg, VA.

Hydrologic Engineering Center. (2010). "HEC-RAS River analysis system, version 4.1." US Army Corps of Engineers, Davis, CA.

Julian, J. P., and Torres, R. (2006). "Hydraulic erosion of cohesive riverbanks." Geomorphology, 76, 193-206.

Knighton, D. (1998). Fluvial Forms and Processes A New Perspective, Arnold Publishing, New York.

Konsoer, K. M. (2008). "LiDAR, GIS, and multivariate statistical analysis to assess landslide risk, Horseshoe Run watershed, West Virginia," Master of Science, West Virginia University, Morgantown, WV.

Lane, E. W. (1953). "Progress report on studies on the design of stable channels of the Bureau of Reclamation." Proceedings of the American Society of Civil Engineers, 79, 246-261. 
Langendoen, E. J., Lowrance, R. R., and Simon, A. (2009). "Assessing the impact of riparian processes on streambank stability." Ecohydrology, 2, 360-369.

Lawler, D. M., Grove, J. R., Couperthwaite, J. S., and Leeks, G. J. L. (1999). "Downstream change in river bank erosion rates in the Swale-Ouse system, northern England." Hydrological Processes, 13(7), 977-992.

Losche, C. K., and Beverage, W. W. (1967). "Soil survey of Tucker County and part of Northern Randolph County." United States Department of Agriculture, Soil Conservation Service and Forest Servuce, In cooperation with West Virginia Agricultural Experiment Station.

Magner, J. A., and Brooks, K. N. (2008). "Predicting stream channel erosion in the lacustrine core of the upper Nemadji River, Minnesota (USA) using stream geomorphology metrics." Environmental Geology, 54, 1423-1434.

Micheli, E. R., and Kirchner, J. W. (2002). "Effects of wet meadow riparian vegetation on streambank erosion. 2. Measurements of vegetated bank strength and consequences for failure mechanics." Earth Surface Processes and Landforms, 27, 687-697.

Moerke, A. H., Gerard, K. J., Latimore, J. A., Hellenthal, R. A., and Lamberti, G. A. (2004). "Restoration of an Indiana, USA, stream: bridging the gap between basic and applied lotic ecology." Journal of the American Benthological Society, 23(3), 647-660. 
Morgenstern, N. R., and Price, V. E. (1965). "The analysis of the stability of general slip surfaces." Geotechnique, 15, 79-93.

Palmer, M. A., Bernhardt, E. S., Allan, J. D., Lake, P. S., Alekander, G., Brooks, S., Carr, J., Clayton, S., Dahm, C. N., Shah, J. F., Galat, D. L., Loss, S. G., Goodwin, P., Hart, D. D., Hassett, B., Jenkinson, R., Kondolf, G. M., Lave, R., Meyer, J. L., O'Donnell, T. K., Pagano, L., and Sudduth, E. (2005). "Standards for Ecologically Successful River Restoration." Journal of Applied Ecology, 42, 208-217.

Papanicolaou, A. N., Elhakeem, M., and Hilldale, R. (2007). "Secondary current effects on cohesive river bank erosion." Water Resources Research, 43, W12418.

Piercy, C., and Wynn, T. (2008). "Predicting root density in streambanks." Journal of the American Water Resources Association, 44(2), 496-508.

Pizzuto, J. (2009). "An empirical model of event scale cohesive bank profile evolution." Earth Surface Processes and Landforms, 34, 1234-1244.

Pollen, N. (2007). "Temporal and spatial variability in root reinforcement of streambanks: Accounting for soil shear stength and moisture." Catena, 69, 197-205.

Pollen, N., and Simon, A. (2005). "Estimating the mechanical effects of riparian vegetation on stream bank stability using a fiber bundle model." Water Resources Research, 41. 
Pollen-Bankhead, N., and Simon, A. (2008). "Enhanced application of root-reinforcement algorithms for bank-stability modeling." Earth Surface Processes and Landforms, 34, 471-480.

Pollen-Bankhead, N., and Simon, A. (2009). "Enhanced application of root-reinforcement algorithms for bank-stability modeling." Earth Surface Processes and Landforms, 34, 471-480.

Pollen-Bankhead, N., Simon, A., Jaeger, K., and Wohl, E. (2009). "Destabilization of streambanks by removal of invasive species in Canyon de Chelly National Monument, Arizona." Geomorphology, 103, 363-274.

Prosser, I. P., Hughes, A. O., and Rutherford, I. D. (2000). "Bank erosion of an incised upland channel by subaerial processes: Tasmania, Australia." Earth Surface Processes and Landforms, 25, 1058-1101.

Reger, D. B. (1923). "County Reports, Tucker County." West Virginia Geologic Survey.

Rinaldi, M., Mengoni, B., Luppi, L., Darby, S. E., and Mosselman, E. (2008). "Numerical simulation of hydrodynamics and bank erosion in a river bend." Water Resources Research, 44(W09428). 
Rosgen, D. L. (1973). "The use of color infrared photography for the determination of sediment production." Fluvial Processes and Sedimentation, Canadian National Research Council, Edmonton, Alberta, Canada, 381-402.

Rosgen, D. L. (1976). "The use of color infrared photography for the determination of suspended sediment concentrations and source areas." Proceedings of the third inter-agency sediment conference, Water Resources Council, Chap. 7, 30-42.

Sekely, A. C., Mulla, D. J., and Bauer, D. W. (2002). "Streambank slumping and its contribution to the phosphorous and suspended sediment loads of the Blue Earth River, Minnesota." Journal of Soil and Water Conservation, 57, 243-250.

Shields, A. (1936). Anwendung der Ahnlichkeitsmechanik und Turbulenzforschung auf die Geschiebebewegung. Report 26, Mitteil. Preus. Versuchsant. Wasserbau and Schiffsbau, Berlin, 1-24.

Simon, A., and Collison, A. (2002). "Quantifying the mechanical and hydrologic effects of riparian vegetation on streambank stability." Earth Surface Processes and Landforms, 27, 527-546.

Simon, A., and Curini, A. (1998). "Pore pressure and bank stability: The influence of matric suction." Water Resources Engineering '98, S. R. Abt, J. Young-Pezeshk, and C. C. Watson, eds., ASCE, Reston, 358-363. 
Simon, A., Curini, A., Darby, S., and Langendoen, E. (2000). "Bank and near-bank procsses in an incised channel." Geomorphology, 35, 193-217.

Simon, A., Langendoen, E. J., and Thomas, R. (2003). "Incorporating bank toe erosion by hydraulic shear into a bank-stability model: Missouri River, Eastern Montana."

Simon, A., Pollen, N., and Langendeon, E. (2006). "Influence of two woody riparian species on critical conditions for streambank stability: Upper Truckee River, California." Journal of the American Water Resources Association, 42(1), 99-113.

Simon, A., Pollen-Bankhead, N., Mahacek, V., and Langendoen, E. (2009). "Quantifying reductions of mass-failure frequency and sediment loadings from streambanks using toe protection and other means: Lake Tahoe, United States." Journal of the American Water Resources Association, 45(1), 170-186.

Simon, A., and Rinaldi, M. (2006). "Disturbance, stream incision, and channel evolution: The roles of excess transport capacity and boundary materials in controlling channel response." Geomorphology, 79(3-4), 361-383.

Simon, A., Thomas, R., Curini, A., and Bankhead, N. (last modified 9/11/2009). "Bank-Stability and Toe-Erosion Model Static Version 5.2." USDA-ARS National Sedimentation Laboratory Oxford, MS. 
Thorne, C. R. "Field measurements of rates of bank erosion and bank material strength." Proceedings of the Florence Symposium.

Thorne, C. R., and Tovey, N. K. (1990). "Stability of composite river banks." Earth Surface Processes and Landforms, 6, 469-484.

Trimble, S. (1997). "Contribution of stream channel erosion to sediment yield from an urbanizing watershed." Science, 278(5342), 1442-1444.

U.S. Environmental Protection Agency. (1999). "Protocol for developing sediment TMDLs." EPA 841-B-99-004 Office of Water (4503FF), United States Environmental Protection Agency, Washington D.C. 132 pp.

Wallick, J. R., Lancaster, S. T., and Bolte, J. P. (2006). "Determination of bank erodibility for natural and anthropogenic bank materials using a model of lateral migration and observed erosion along the Willamette River, Oregon, USA." River Research and Applications, 22, 631-649.

Wilcock, P., Pitlick, J., and Cui, Y. (2009). "Sediment transport primer: estimating bed-material transport in gravel-bed rivers." Gen. Tech. Rep. RMRS-GTR-226, U.S. Department of Agriculture, Forest Service, Rocky Mountain Research Station, Fort Collins, CO.

Wilcock, P. R. (1993). "The critical shear stress of natural sediments." The Journal of Hydraulic Engineering, 119(4), 491-505. 
Wilcock, P. R., Kenworthy, S. T., and Crowe, J. C. (2001). "Experimental study of the transport of mixed sand and gravel." Water Resources Research, 37(12), 3349-3358.

Wu, T. H., III, W. P. M., and Swanson, D. N. (1979). "Strength of tree roots and landsclides on Prince of Wales Island, Alaska." Canadian Geotechnical Journal, 16(1), 19-33.

Wynn, T., and Mostaghimi, S. (2006). "The effects of vegetation and soil type on streambank erosion, southwestern Virginia, USA." Journal of the American Water Resources Association, 42(1), 69-82. 
Figure 2.1: Horseshoe Run watershed and project vicinity within the Allegheny Mountain Section of the Appalachian Plateau Physiographic Province, West Virginia.

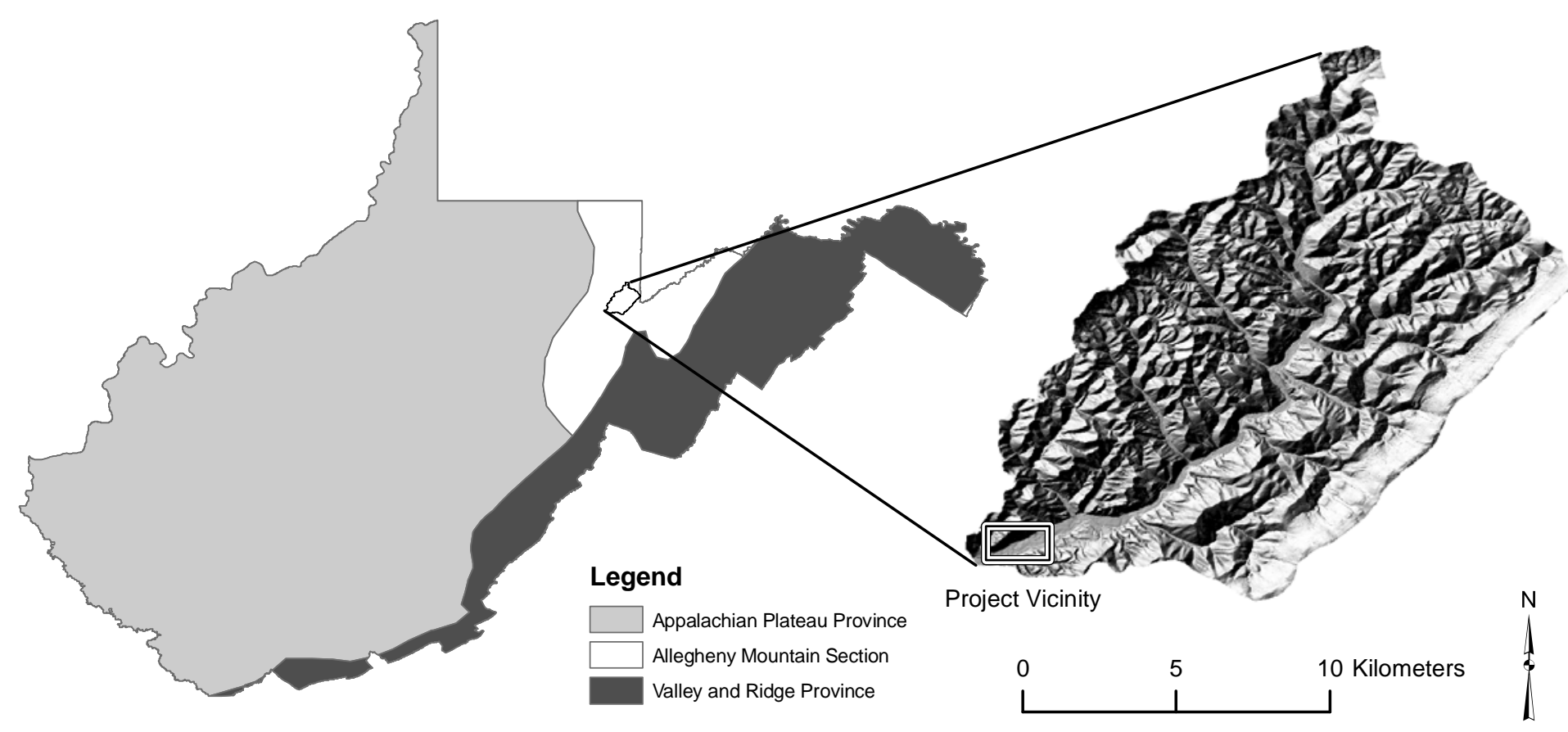


Figure 2.2: Streambank sites used for calibrating and testing BSTEM. Streamflow is from left to right. (2006 LiDAR digital elevation model and aerial photo maps provided by Canaan Valley Institute).

Table 2.1: BSTEM parameters with definitions, units, and identification of whether the parameter was measured, estimated/derived, selected by the model, or calibrated (x).

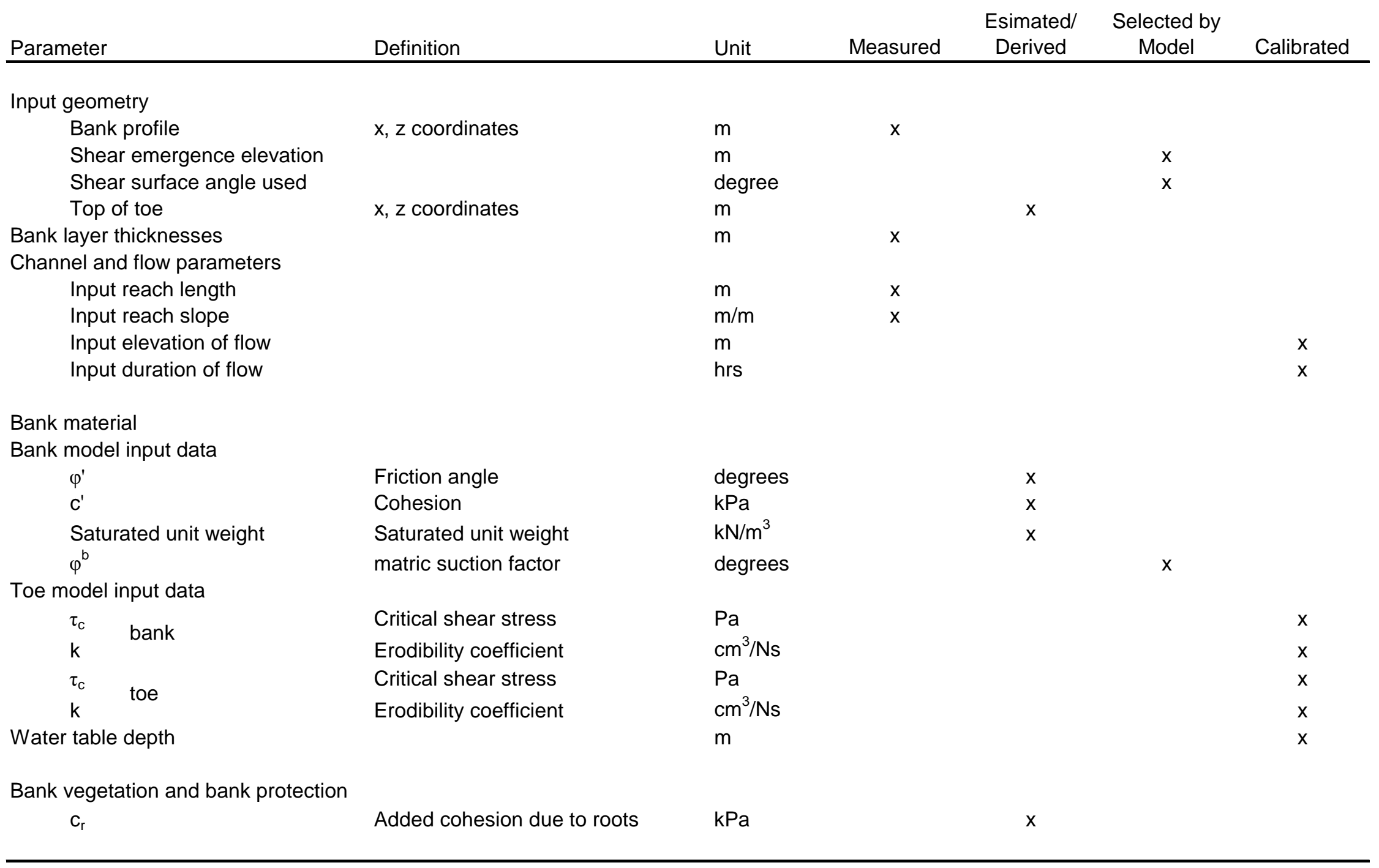


Table 2.2: Geomorphic data for the six streambank study sites used to calibrate and test BSTEM at Horseshoe Run, WV.

\begin{tabular}{|c|c|c|c|c|c|c|c|c|c|}
\hline \multirow[b]{2}{*}{ Site } & \multicolumn{4}{|c|}{ Cross Section Geometry } & \multicolumn{3}{|c|}{ Bank Geometry } & \multirow{2}{*}{$\begin{array}{l}\text { Longitudinal } \\
\text { Streambed Slope }\end{array}$} & \multirow[b]{2}{*}{$\mathrm{D} 50(\mathrm{~mm})$} \\
\hline & $\operatorname{Area}\left(m^{2}\right)$ & Width (m) & Mean Depth (m) & Max Depth (m) & Height $(\mathrm{m})$ & Length $(\mathrm{m})$ & Angle $\left({ }^{\circ}\right)$ & & \\
\hline 1 & 88.9 & 78.8 & 1.1 & 2.3 & 1.69 & 0.14 & 136 & 0.0054 & 55 \\
\hline 9 & 42.3 & 76.4 & 0.6 & 1.3 & 1.2 & 0.49 & 32 & 0.0041 & 50 \\
\hline 11 & 149.7 & 115.8 & 1.3 & 2.3 & 2.03 & 0.73 & 68 & 0.0041 & 54 \\
\hline 19 & 53.4 & 65.6 & 0.8 & 2.5 & 2.37 & 9.68 & 20 & 0.0069 & 60 \\
\hline 21 & 48.6 & 37.5 & 1.3 & 2.3 & 1.85 & 7.47 & 16 & 0.0049 & 79 \\
\hline 22 & 43.3 & 46.2 & 0.9 & 2.7 & 1.81 & 7.5 & 15 & 0.0032 & 86 \\
\hline
\end{tabular}


Figure 2.3: Averaged precipitation from the Davis 3SE and Parsons 1NE National Climate Data Center weather stations and streamflow stage from the Canaan Valley Institute streamgage for the study period. Solid horizontal line represents the stage required for flow to overtop banks for the average bank height through the study area. Lower dotted line represents the stage required to overtop the shortest study bank while upper dotted line represents the stage required to overtop the tallest study bank. Gaps in streamflow represent missing data.

Figure 2.4: BSTEM was run iteratively where the input elevation and duration of flow were changed with each iteration to model the entire study period. Stage data from the upstream gage were discretized into various duration intervals. Each simulation (A-F) represents a unique series of duration intervals and total number of model iterations. 22 iterations were run to generate predicted erosion for simulation $A$ where the minimum flow duration was 24 hours and the maximum was 1,767 hours. 685 iterations were run to generate predicted erosion for simulation $F$ where the minimum flow duration was 1 hour and the maximum was 1,767 hours. Simulation $D$ was found to be the most efficient series of duration intervals and model iterations for sites 9 and 21. These flow duration intervals and corresponding streamflow elevation data were used to model erosion at the other four sites.

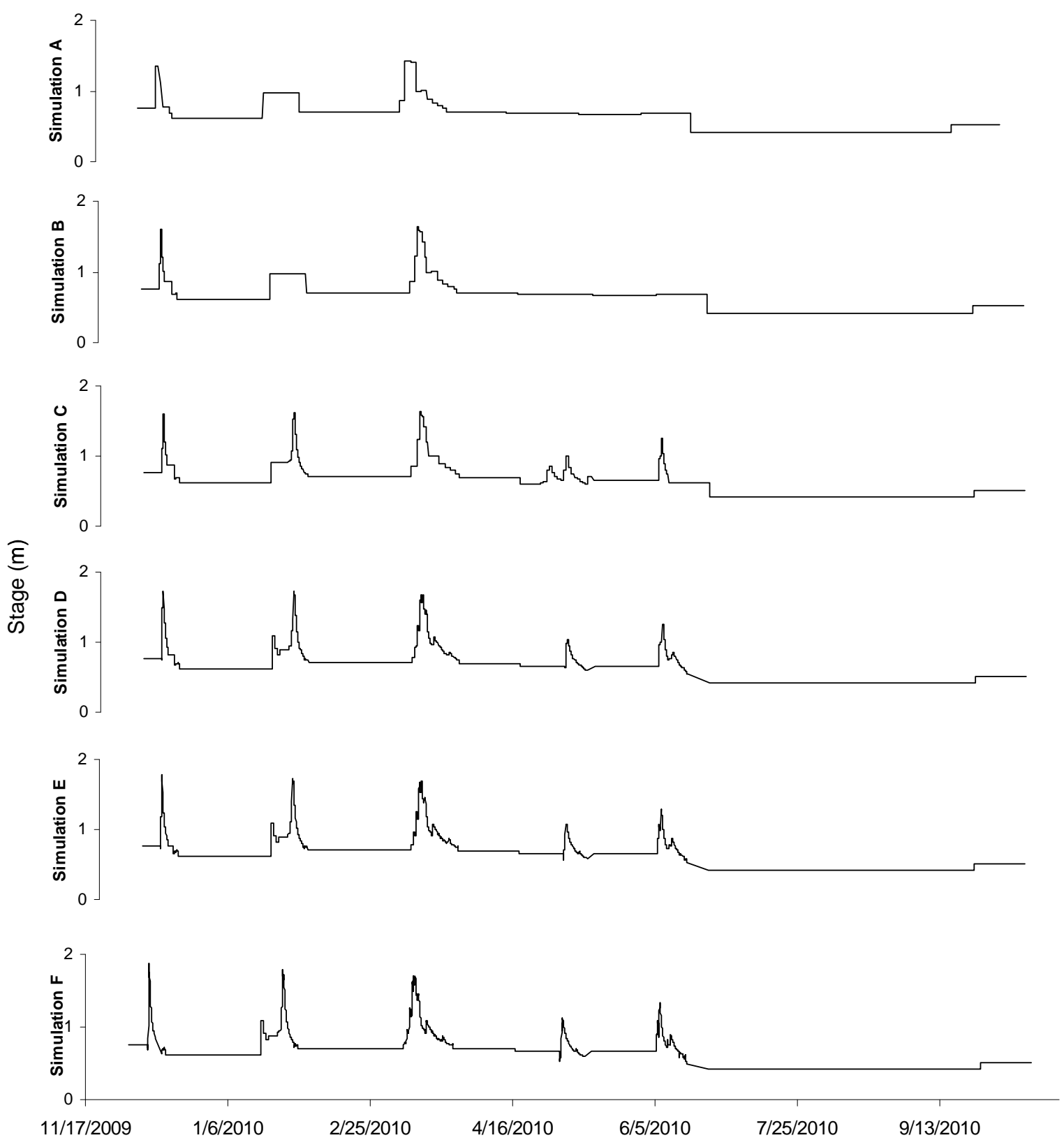


Table 2.3: BSTEM was run iteratively where the input elevation and duration of flow were changed with each iteration to model the entire study period. Stage data from the upstream gage were discretized into various duration intervals. Each simulation (A-F) represents a unique series of duration intervals and total number of model iterations. Summary of dates, durations, and total number of model iterations for each of the hydrograph discretization simulations are listed below. Minimum and maximum durations for each simulation are outlined. 22 iterations were run to generate predicted erosion for simulation A where the minimum flow duration was 24 hours and the maximum was 1,767 hours. 685 iterations were run to generate predicted erosion for simulation $F$ where the minimum flow duration was 1 hour and the maximum was 1,767 hours. Simulation $D$ was found to be the most efficient series of duration intervals and model iterations for sites 9 and 21. These flow duration intervals and corresponding streamflow elevation data were used to model erosion at the other four sites.

\begin{tabular}{|c|c|c|c|c|c|c|c|c|c|c|c|c|c|c|}
\hline \multirow{2}{*}{\multicolumn{2}{|c|}{ Dates }} & \multirow[b]{3}{*}{$\begin{array}{c}\text { Event } \\
\#\end{array}$} & \multicolumn{12}{|c|}{ Simulations } \\
\hline & & & \multicolumn{2}{|c|}{$A$} & \multicolumn{2}{|c|}{$\mathrm{B}$} & \multicolumn{2}{|c|}{$\mathrm{C}$} & \multicolumn{2}{|c|}{$\mathrm{D}$} & \multicolumn{2}{|c|}{$E$} & \multicolumn{2}{|c|}{$\mathrm{F}$} \\
\hline Begin & End & & $\begin{array}{l}\text { Duration } \\
\text { (h) }\end{array}$ & $\begin{array}{l}\text { \# Model } \\
\text { Iterations }\end{array}$ & $\begin{array}{l}\text { Duration } \\
\text { (h) }\end{array}$ & $\begin{array}{l}\text { \# Model } \\
\text { Iterations }\end{array}$ & $\begin{array}{l}\text { Duration } \\
\text { (h) }\end{array}$ & $\begin{array}{l}\text { \# Model } \\
\text { Iterations }\end{array}$ & $\begin{array}{l}\text { Duration } \\
\text { (h) }\end{array}$ & $\begin{array}{l}\text { \# Model } \\
\text { Iterations }\end{array}$ & $\begin{array}{l}\text { Duration } \\
\text { (h) }\end{array}$ & $\begin{array}{l}\text { \# Model } \\
\text { Iterations }\end{array}$ & $\begin{array}{l}\text { Duration } \\
\text { (h) }\end{array}$ & $\begin{array}{c}\text { \# Model } \\
\text { Iterations }\end{array}$ \\
\hline $12 / 2 / 2009$ & $12 / 8 / 2009$ & 1 & 157 & 1 & 157 & 1 & 157 & 1 & 157 & 1 & 157 & 1 & 157 & 1 \\
\hline \multirow[t]{2}{*}{$12 / 8 / 2009$} & $12 / 10 / 2009$ & 2 & 24 & 4 & 12 & 8 & 12 & 8 & 6 & 16 & 3 & 32 & 1 & 96 \\
\hline & & & & & & & & & 24 & 3 & 24 & 3 & 24 & 3 \\
\hline \multirow[t]{2}{*}{$1 / 17 / 2010$} & 1/30/2010 & 3 & 317 & 1 & 317 & 1 & 317 & 1 & 72 & 1 & 72 & 1 & 72 & 1 \\
\hline & & & & & & & & & 6 & 29 & 3 & 58 & 1 & 174 \\
\hline \multirow[t]{2}{*}{$1 / 30 / 2010$} & $3 / 8 / 2010$ & 4 & 890 & 1 & 890 & 1 & 890 & 1 & 890 & 1 & 890 & 1 & 890 & 1 \\
\hline & & & & & 48 & 1 & 48 & 1 & 12 & 4 & 48 & 1 & 48 & 1 \\
\hline \multirow[t]{2}{*}{$3 / 8 / 2010$} & $3 / 25 / 2020$ & 5 & 48 & 9 & 12 & 8 & 12 & 8 & 6 & 16 & 3 & 32 & 1 & 96 \\
\hline & & & & & 48 & 6 & 48 & 6 & 12 & 24 & 48 & 6 & 48 & 6 \\
\hline $3 / 25 / 2010$ & 4/16/2010 & 6 & 526 & 1 & 526 & 1 & 526 & 1 & 526 & 1 & 526 & 1 & 526 & 1 \\
\hline \multirow{2}{*}{ 4/16/2010 } & & & & & & & 424 & 1 & 424 & 1 & 424 & 1 & 424 & 1 \\
\hline & 5/13/2010 & 7 & 640 & 1 & 640 & 1 & 12 & 18 & 12 & 18 & 6 & 36 & 1 & 216 \\
\hline $5 / 13 / 2010$ & $6 / 5 / 2010$ & 8 & 555 & 1 & 555 & 1 & 555 & 1 & 555 & 1 & 555 & 1 & 555 & 1 \\
\hline \multirow{2}{*}{ 6/5/2010 } & $6 / 23 / 2010$ & 9 & 407 & 1 & 407 & 1 & 12 & 7 & 12 & 7 & 6 & 14 & 1 & 84 \\
\hline & $0 / \angle 3 / \angle 0 \perp 0$ & 9 & 407 & 1 & 407 & 1 & 323 & 1 & 323 & 1 & 323 & 1 & 323 & 1 \\
\hline $6 / 23 / 2010$ & 9/27/2010 & 10 & 1767 & 1 & 1767 & 1 & 1767 & 1 & 1767 & 1 & 1767 & 1 & 1767 & 1 \\
\hline 9/27/2010 & $10 / 15 / 2010$ & 11 & 431 & 1 & 431 & 1 & 431 & 1 & 431 & 1 & 431 & 1 & 431 & 1 \\
\hline
\end{tabular}


Figure 2.5: BSTEM was run iteratively where the input elevation and duration of flow were changed with each iteration to model erosion for the entire study period. Stage data from the upstream gage were discretized into various duration intervals. Each simulation (A-F) represents a unique series of duration intervals and total number of model iterations. Bars below represent the predicted erosion for each simulation and the measured erosion at these two sites. Simulation D was found to be the most efficient series of duration intervals and model iterations for sites 9 and 21 . These flow duration intervals and corresponding streamflow elevation data were used to model erosion at the other four sites.

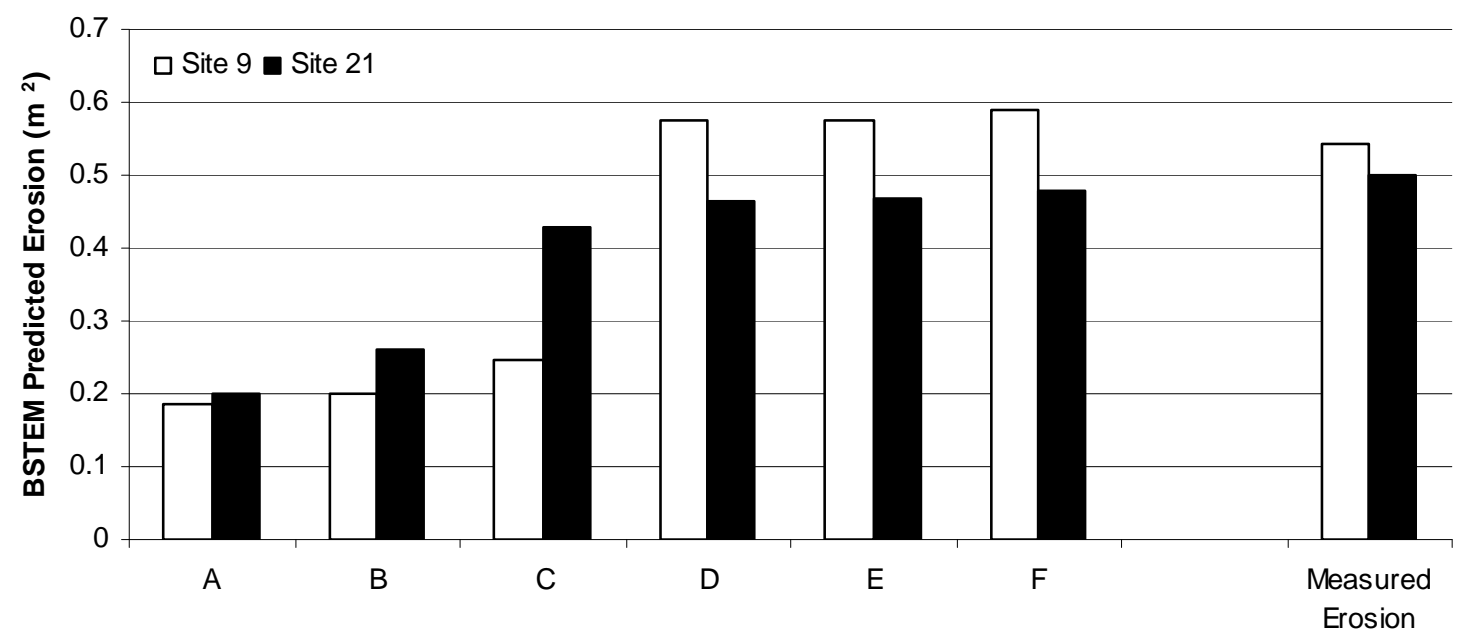

Hydrograph Discretization Simulation 
Table 2.4: Bank and toe material values provided in BSTEM are listed in the upper half of the table and weighted average values of these same parameters based on the laboratory determined soil textural classification are listed in the lower half of the table.

\begin{tabular}{|c|c|c|c|c|c|c|c|}
\hline \multicolumn{2}{|c|}{ Material Descriptors } & \multicolumn{4}{|c|}{ Bank Model Input Data } & \multicolumn{2}{|c|}{ Toe Model Input Data } \\
\hline Description & $\begin{array}{l}\text { Mean grain } \\
\text { size, } D_{50}(m)\end{array}$ & $\begin{array}{l}\text { Friction } \\
\text { angle } \phi^{\prime} \\
\text { (degrees) }\end{array}$ & Cohesion $c^{\prime}(k P a)$ & $\begin{array}{c}\text { Saturated } \\
\text { unit } \\
\text { weight } \\
\left(\mathrm{kN} / \mathrm{m}^{3}\right)\end{array}$ & $\begin{array}{c}\phi^{b} \\
\text { (degrees) }\end{array}$ & $\tau_{\mathrm{c}}(\mathrm{Pa})$ & $\begin{array}{c}k \\
\left(\mathrm{~cm}^{3} / \mathrm{Ns}\right)\end{array}$ \\
\hline Boulders & 0.512 & 42.0 & 0.0 & 20.0 & 15 & 498 & 0.004 \\
\hline Cobbles & 0.128 & 42.0 & 0.0 & 20.0 & 15 & 124 & 0.009 \\
\hline Gravel & 0.0113 & 36.0 & 0.0 & 20.0 & 15 & 11.0 & 0.030 \\
\hline Angular sand & 0.00035 & 36.0 & 0.0 & 18.0 & 15 & \multirow{2}{*}{\multicolumn{2}{|c|}{$\begin{array}{l}\text { Coarse }(0.71 \mathrm{~mm}) \text { or } \\
\text { Fine }(0.18 \mathrm{~mm})\end{array}$}} \\
\hline Rounded sand & 0.00035 & 27.0 & 0.0 & 18.0 & 15 & & \\
\hline Silt & - & 30.0 & 3.0 & 18.0 & 15 & \multirow{3}{*}{\multicolumn{2}{|c|}{$\begin{array}{c}\text { Erodible }(0.100 \mathrm{~Pa}), \\
\text { Moderate }(5.00 \mathrm{~Pa}), \text { or } \\
\text { Resistant }(50.0 \mathrm{~Pa})\end{array}$}} \\
\hline Soft clay & - & 25.0 & 10.0 & 18.0 & 15 & & \\
\hline Stiff clay & - & 20.0 & 15.0 & 18.0 & 15 & & \\
\hline \multicolumn{8}{|c|}{ Site(Soil Horizon) Description } \\
\hline 9(a) clay & & 27.3 & 5.8 & 18.0 & 15 & 21.19 & 0.112 \\
\hline 9(b) gravelly $s$ & ndy loam & 35.0 & 0.4 & 19.7 & 15 & 10.69 & 0.047 \\
\hline 1(a) clay loam & & 28.5 & 4.6 & 18.1 & 15 & 16.40 & 0.128 \\
\hline 1(b) gravelly $s$ & ndy clay loam & 34.6 & 0.6 & 19.6 & 15 & 11.00 & 0.051 \\
\hline 11(a) gravelly $s$ & ndy loam & 34.2 & 0.6 & 19.4 & 15 & 10.20 & 0.059 \\
\hline 11(b) gravelly $s$ & ndy loam & 35.4 & 0.3 & 19.8 & 15 & 10.70 & 0.043 \\
\hline 11(c) gravelly I & my sand & 34.6 & 0.3 & 19.5 & 15 & 9.40 & 0.055 \\
\hline
\end{tabular}


Table 2.5: Vegetation summary data for sites 1, 9, and 11 used as input to RipRoot and associated RipRoot cohesion output values. Percentages of each type of vegetation is used as input in combination with either root tensile strength coefficients ( $a$ and $b$ where root tensile strength $=a D^{b}$ and $\mathrm{D}$ is the number of roots per diameter size class) or age. indicates that age was used with percentages. NA indicates that age was not used. Root tensile strength coefficients for Rosa multiflora were determined by averaging those coefficients in the model for the Rosaceae family. Root tensile strength coefficients for Aesculus flava were determined by averaging those coefficients in the model for all tree species.

\begin{tabular}{|c|c|c|c|c|c|c|c|c|}
\hline \multirow[b]{2}{*}{ Site } & \multirow[b]{2}{*}{ Vegetation } & \multirow[b]{2}{*}{ Species } & \multirow[b]{2}{*}{ a } & \multirow[b]{2}{*}{$\mathrm{b}$} & \multirow[b]{2}{*}{$\%$} & \multirow[b]{2}{*}{ Age } & \multicolumn{2}{|c|}{ Added cohesion due to roots $(\mathrm{kPa})$} \\
\hline & & & & & & & RipRoot & $\mathrm{Wu}$ \\
\hline \multirow[t]{2}{*}{1} & Betula nigra & Betula nigra & $\sim$ & $\sim$ & 90 & 39 & \multirow{2}{*}{6.25} & \multirow{2}{*}{63.02} \\
\hline & poaceae & dry meadow & $\sim$ & $\sim$ & 10 & 2 & & \\
\hline \multirow[t]{4}{*}{9} & poaceae & dry meadow & $\sim$ & $\sim$ & 50 & 2 & & \multirow{4}{*}{40.34} \\
\hline & Rosa muliflora & own & 21.2 & -0.615 & 30 & $N A$ & \multirow{3}{*}{8.12} & \\
\hline & poaceae & wet meadow & $\sim$ & $\sim$ & 10 & 2 & & \\
\hline & bare & bare & - & - & 10 & NA & & \\
\hline \multirow[t]{5}{*}{11} & Rosa muliflora & own & 21.2 & -0.615 & 30 & $N A$ & \multirow{5}{*}{18.36} & \multirow{5}{*}{152.53} \\
\hline & Aesculus flava & own & 39.65 & -0.76 & 15 & $N A$ & & \\
\hline & Aesculus flava & own & 39.65 & -0.76 & 15 & $N A$ & & \\
\hline & poaceae & dry meadow & $\sim$ & $\sim$ & 30 & 2 & & \\
\hline & bare & bare & - & - & 10 & NA & & \\
\hline
\end{tabular}


Table 2.6: Seven simulations were run for site 9. In simulations 1-3, the vegetative cohesion values were altered based on the RipRoot predicted cohesion, the apparent cohesion (Wu 1979) and no added cohesion from roots. Simulations 4-5 were run with the default bank and toe model parameters for gravel and clay since the bank material at the site ranged from gravel size to clay size material. Simulations 6-7 represented conditions where the water table in the streambank was set to the elevation of the previous iteration to represent bank storage conditions. The water table elevation was set equal to the stream flow elevation for each iteration for all other model results. Since $F_{s}$ was not less than 1 for Simulation 2 and 5 , due to the added cohesion of roots and clay respectively, these can be eliminated as potentially improved simulations. Simulations 3 and 4 can be eliminated because the model unrealistically predicted mass failure prior to any flow due to the lack of cohesion by roots and gravel respectively, and this cannot be the case because the bank was stable during initial data collection. Simulation 6 was run so that the flow elevation from the previous iteration was input as the new groundwater elevation for the next iteration during flow events. This scenario increased the weight of the bank above the streamflow because of the sustained pore water and eliminated the confining pressure created by the streamflow so that the pore water pressure in the bank was not counter pressured by the streamflow. The model was calibrated with this scenario for site 9 as well.

\begin{tabular}{|c|c|c|c|c|c|c|c|c|}
\hline Simulation & $\begin{array}{c}\text { Bank material } \\
\text { parameters }\end{array}$ & $\begin{array}{l}\text { Critical shear } \\
\text { stress }(\mathrm{Pa})\end{array}$ & $\begin{array}{c}\text { Erodibility } \\
\text { coefficient } \\
\left(\mathrm{cm}^{3} / \mathrm{Ns}\right)\end{array}$ & $\begin{array}{l}\text { Vegetative } \\
\text { cohesion }\end{array}$ & Water table & $F_{s}<1$ & \% Error & Notes \\
\hline 1 & weighted average & 20.17 & 0.022 & RipRoot & $=$ flow & Yes & $-6 \%$ & retained for testing \\
\hline 2 & weighted average & 20.17 & 0.022 & Wu & $=$ flow & No & $52 \%$ & no bank failure \\
\hline 3 & weighted average & 20.17 & 0.022 & 0 & $=$ flow & Yes & $51 \%$ & immediate failure \\
\hline 4 & default gravel & 20.17 & 0.022 & Riproot & $=$ flow & Yes & $56 \%$ & immediate failure \\
\hline 5 & default clay & 20.17 & 0.022 & Riproot & $=$ flow & No & $52 \%$ & no bank failure \\
\hline 6 & weighted average & 20.17 & 0.022 & Riproot & delayed & Yes & $53 \%$ & needs calibrated for critical shear stress \\
\hline 7 & weighted average & 15.55 & 0.025 & Riproot & delayed & Yes & $7 \%$ & retained for testing \\
\hline
\end{tabular}


Figure 2.6: BSTEM predicted erosion as a function of the particle diameter used to infer critical shear stress for sites 19, 21 and 22. A number of simulations (solid symbols) were run for each streambank site altering only the critical shear stress which was determined from the non-cohesive particle diameter and the Shields curve and Lane adjustment. The actual measured erosion for each site is identified on the curve with squares.

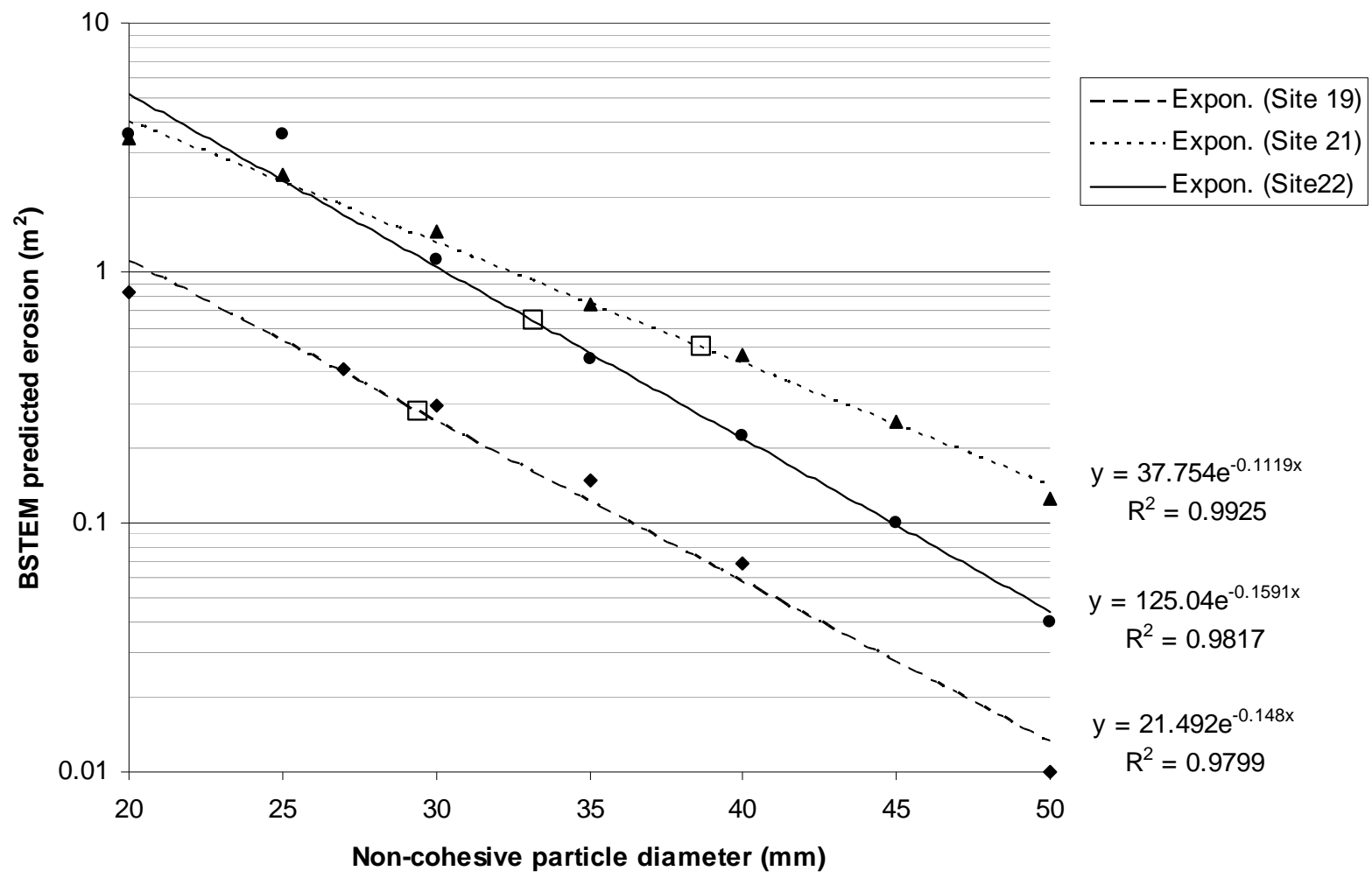


Figure 2.7: Cumulative percent graph of the 20 particle diameters measured along the bank profile for sites 19, 21, and 22. The non-cohesive particle diameters corresponding to the actual erosion amount from Figure 2.6 are also included in the graph with squares.

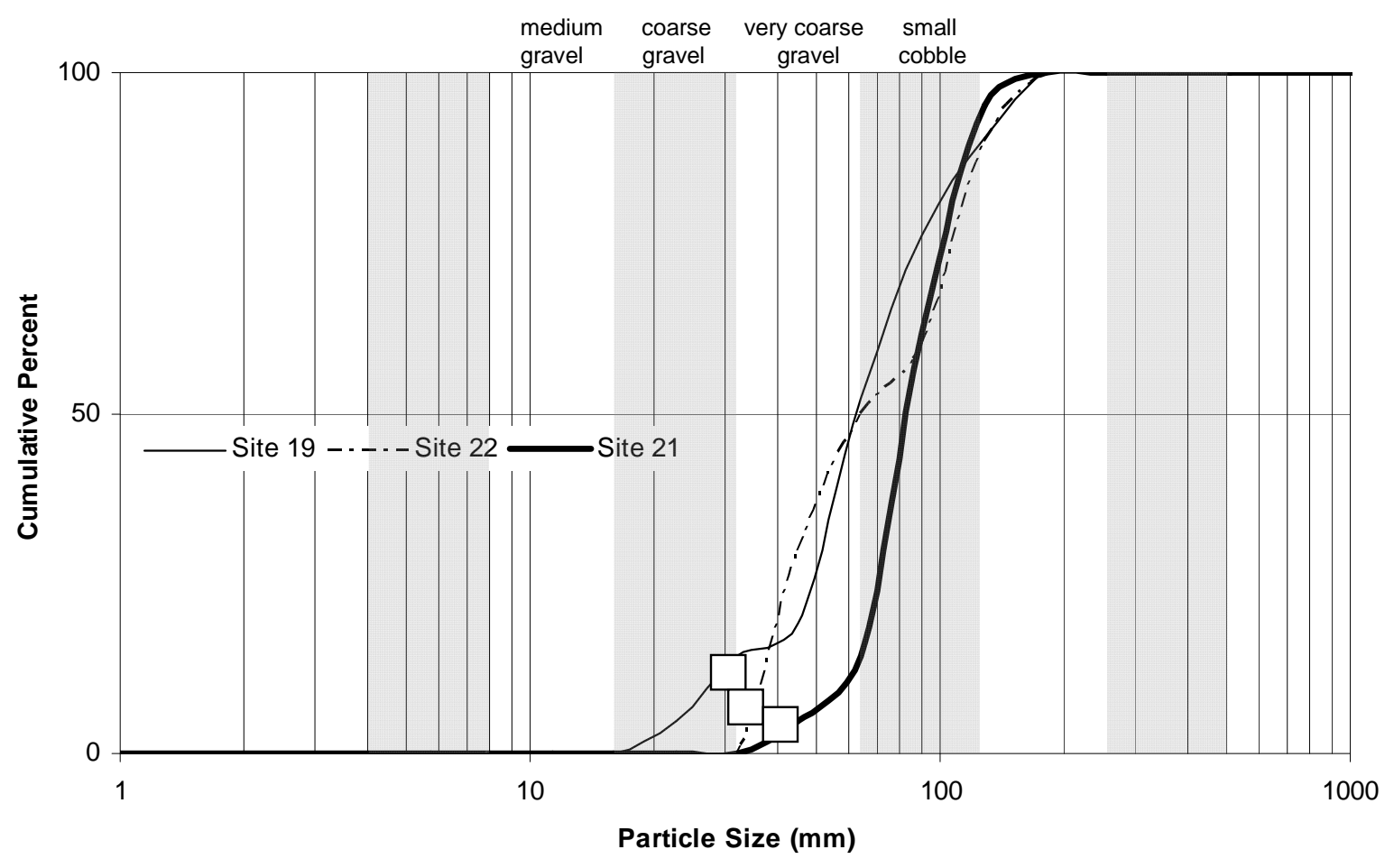


Figure 2.8: Particle diameter distribution from the pebble counts for sites 19, 21, and 22. Site 22 has a slightly bimodal distribution with a peak in the very coarse gravel range and a peak in the small cobble range.




Table 2.7: Parameters used as input to test the model prediction capabilities at four additional sites with prediction error.

\begin{tabular}{cccccccc} 
Site & $\begin{array}{c}\text { Critical shear } \\
\text { stress }(\mathrm{Pa})\end{array}$ & $\begin{array}{c}\text { Erodibility } \\
\text { coefficient } \\
\text { (cm3/Ns) }\end{array}$ & $\begin{array}{c}\text { Vegetative } \\
\text { cohesion }\end{array}$ & $\begin{array}{c}\text { Bank material } \\
\text { parameters }\end{array}$ & Water table & Fs<1 & $\%$ Error \\
\hline 19 & 37.91 & 0.016 & NA & default gravel & $=$ flow & No & $76 \%$ \\
22 & 37.91 & 0.016 & NA & default gravel & $=$ flow & No & $60 \%$ \\
1 & 20.17 & 0.022 & RipRoot & weighted average & $=$ flow & Yes & $68 \%$ \\
11 & 20.17 & 0.022 & RipRoot & weighted average & $=$ flow & No & $-10 \%$ \\
1 & 15.55 & 0.025 & RipRoot & weighted average & delayed & Yes & $>-500 \%$ \\
11 & 15.55 & 0.025 & RipRoot & weighted average & delayed & No & $-10 \%$ \\
\hline
\end{tabular}


Figure 2.9: The bank profile overlays for site 11 indicate that the majority of erosion occurred in the upper bank layers.

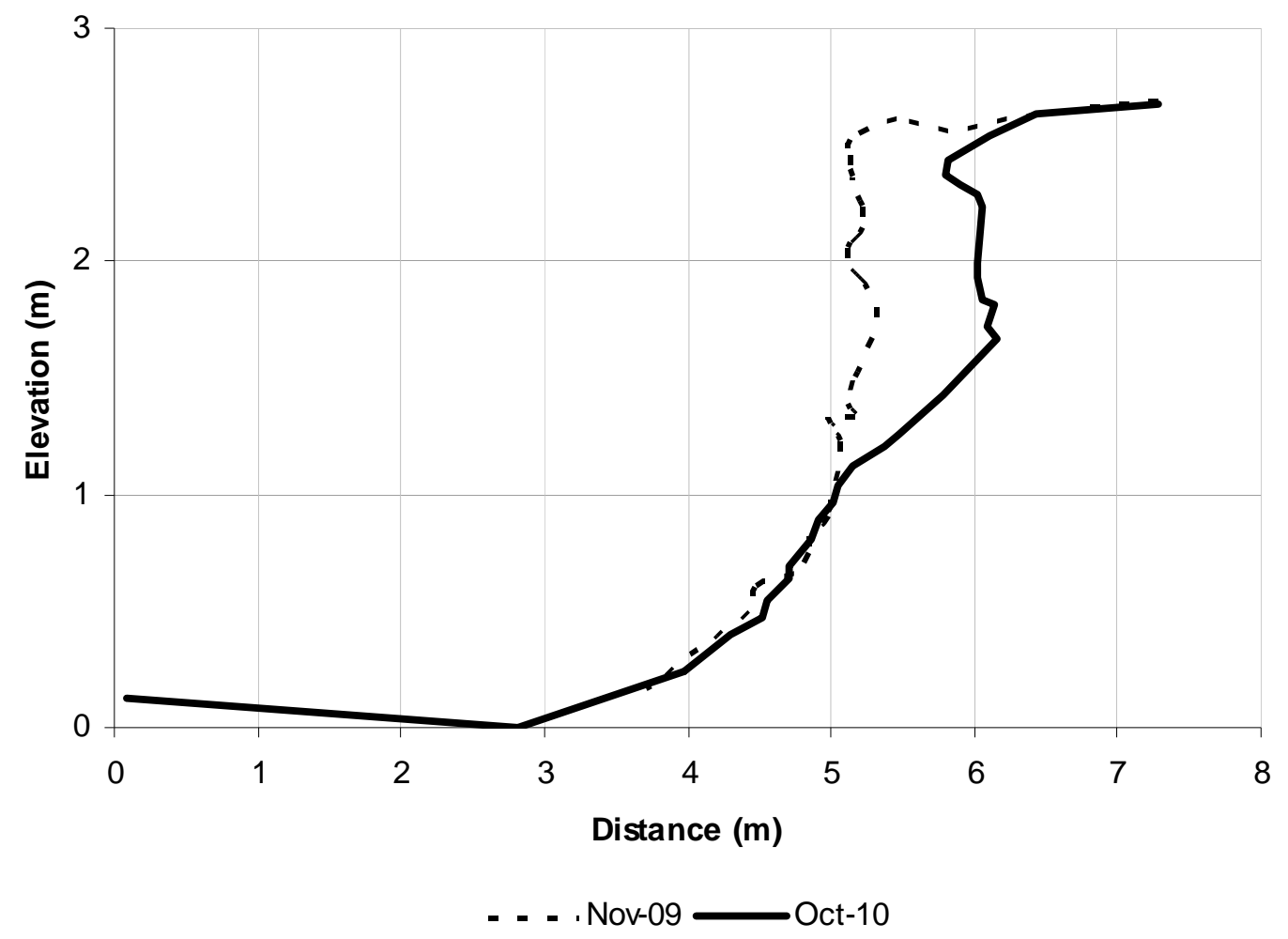


Figure 2.10: A plot of the observed versus BSTEM predicted erosion indicated that the model accurately predicted relative amounts of erosion with only one exception, site 22 . Squares are calibrated sites, circles are test sites. A 1:1 line is depicted on the diagonal. Site 22 had the third highest observed erosion but the second lowest BSTEM predicted erosion. This difference is likely due to the local variation in shear stress.

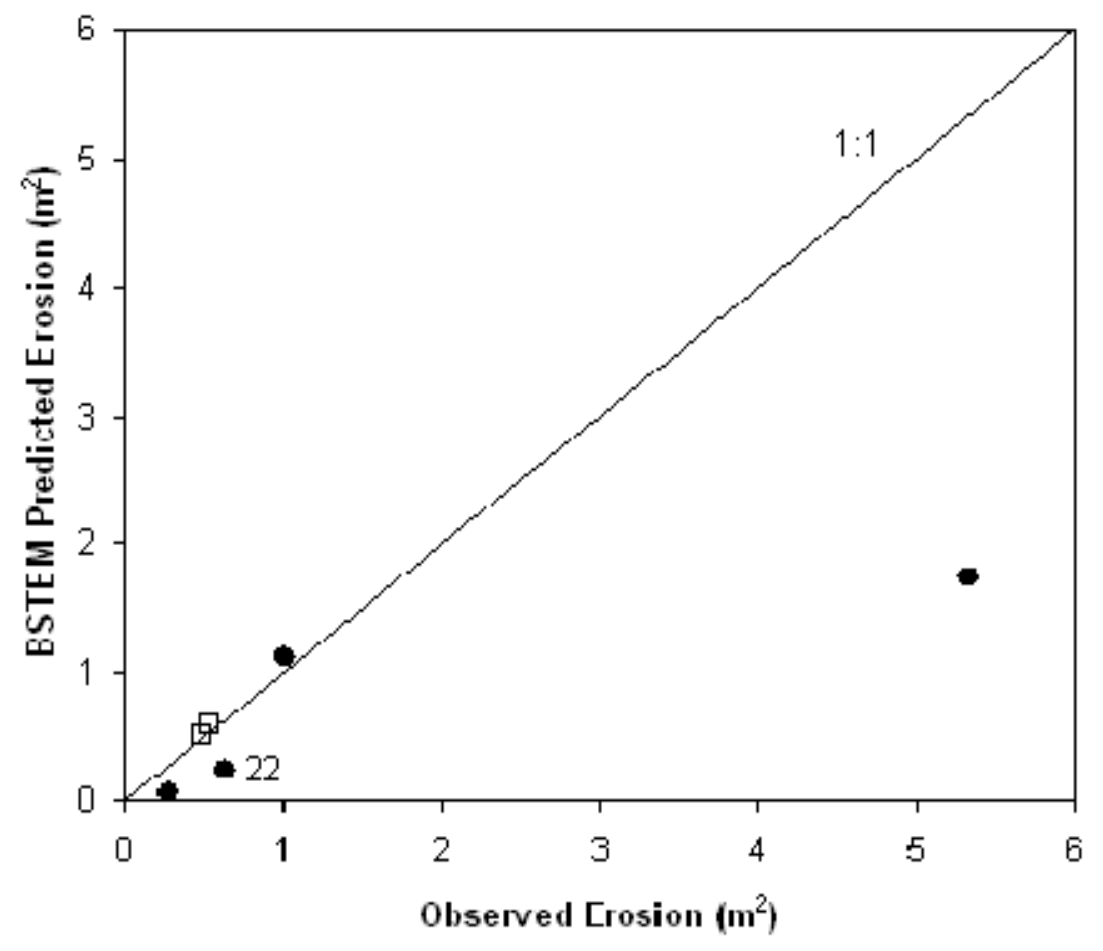




\section{Can the BANCS model parameters be used to predict streambank erosion at contrasting reaches: A case study at Horseshoe Run in Tucker County, West Virginia?}

\subsection{Abstract}

The input parameters for the BANCS model may be used to explain the susceptibility of a streambank to erosion. However, careful consideration needs to be given when using streambank and near bank characteristics to predict relative erosion on sections of the same stream with different morphology and potentially different dominant erosional processes. When the streambank parameters were used to group sites independently of erosion, a group of streambanks with moderate rooting depths and densities, low bank angles, and surface protection emerged. This group experienced the least amount of erosion. This finding encourages the continuation of streambank stabilization practices that involve reducing bank angles, installing erosion control fabric, and planting a variety of vegetation. A variety of vegetation types with a wide distribution of root sizes and depths may provide more stability than larger vegetation with deeper, denser root networks. This may be particular true for incised streams with high hydraulic erosion at the bank toe where the surcharge of large trees may outweigh the stabilizing effects of vegetation. Regression analyses revealed that the different reach morphologies and streambank characteristics did have implications for streambank erosion processes and prediction models. We showed that for non-cohesive restored banks that were vulnerable to fluvial erosion, bank angle, bank height, and vegetation parameters were needed to predict susceptibility to erosion. Alternatively, for cohesive banks with non-cohesive bank toe material that were vulnerable to fluvial erosion and mass failure, bank angle, bank material, and near bank depth ratios with an emphasis on bank angle were sufficient parameters to predict susceptibility. We suggest the following improvements to the BANCS model: regional relationships for converting the measured ratios to index values should be refined as the regional erosion curves are developed, sets of weighting coefficients based on dominant erosion processes should be explored, and the potentially negative effects of vegetation should be incorporated into the model if present at a site. 


\subsection{Introduction}

Erosion and deposition are natural weathering processes that have been shaping the environment for millennia. By altering the landscape and interfering with the natural movement of water through catchments, humans have accelerated these processes. As a consequence, an increasing number of aquatic ecosystems are impaired by sediment. Historically, sediment was thought to originate largely from surface runoff and overland flow. Over the past several decades, sediment originating from streambanks has been realized as a potentially greater source of sediment. Streambank erosion has been found to account for the majority of sediment input to streams in California (Trimble 1997), Montana (Rosgen 1973; Rosgen 1976), Minnesota (Sekely et al. 2002), across the Southeast (Simon and Rinaldi 2006), and in Australia (Prosser et al. 2000), England (Lawler et al. 1999), and Ireland (Evans et al. 2006). However, contemporary models for estimating sediment often do not consider the source because of the difficulty of quantifying streambank erosion. Until we have a better understanding of erosion at the local scale, our ability to develop predictive models will be limited.

Streambanks erode through a combination of streambank weakening, failure of bank materials due to gravity, and detachment of bank materials due to flow (Lawler et al. 1997). The influence of each mechanism to total streambank erosion varies by stream and may vary both spatially and temporally within a single reach. Attempts have been made to generate models that predict streambank erosion. These models can be classified as either mechanistic or empirical (Pizzuto 2009). Empirical models often include a much broader range of variables that either directly or indirectly represent the mechanistic variables. Some common variables that have been used to successfully predict erosion in an empirical approach include freeze thaw cycling, soil bulk density, near bank velocities, cross sectional dimensions, flow conditions (e.g. duration, 
peak), silt-clay content, and various vegetation indices (Chen et al. 2005; Julian and Torres 2006; Magner and Brooks 2008; Pizzuto 2009; Rosgen 2001; Rosgen 2006; Wynn and Mostaghimi 2006). Many of these models have been successfully tested at individual sites; however, there is a need to generate a model with regional applications that can be transferred across sites.

The overall objective of our study is to determine if the Bank Assessment of Nonpoint Source Consequences of Sediment (BANCS) model parameters could be used to predict erosion along a $1.5 \mathrm{~km}$ reach of Horseshoe Run in Tucker County, West Virginia. Specifically, we ask the following questions: (1) Do the upper and lower reach morphologies and streambank characteristics at the study site differ? (2) Can streambanks be grouped into different categories based on BANCS model input parameters and does erosion differ between groups? (3) Do the different reach morphologies and streambank characteristics between the upper and lower reach have implications for streambank erosion processes and predictions?

\subsubsection{BANCS model description}

The BANCS model was developed based on the need of practitioners and watershed managers to have a comparable, transferable model that could be easily and rapidly applied at the watershed scale (Rosgen 1996; Rosgen 2001; Rosgen 2006). This model relies on observations and statistical relationships to predict bank failure and erosion. Combining two submodels, the Bank Erosion Hazard Index (BEHI) and the Near Bank Stress (NBS) with a set of regional erosion curves, the model incorporates the susceptibility of a bank due to mass or gravitational failure, fluvial entrainment, and surface erosion. 


\subsubsection{BEHI submodel}

The Bank Erosion Hazard Index (BEHI) submodel represents the vulnerability of the streambank to all types of erosion. The total BEHI score is a summation of seven individual variable scores or ratings:

$$
B E H I_{\text {Score }}=C_{\text {Score }}+E_{\text {Score }}+G_{\text {Score }}+H_{\text {Score }}+I_{\text {Score }}+J+K \text { (eq.1) }
$$

where $\mathrm{C}=$ study bank height ratio $(\mathrm{m} / \mathrm{m}), \mathrm{E}=$ root depth ratio $(\mathrm{m} / \mathrm{m}), \mathrm{G}=$ weighted root density $(\%), \mathrm{H}=$ bank angle (Degrees) $\mathrm{I}=$ surface protection $(\%), \mathrm{J}=$ bank material adjustment factor, and $\mathrm{K}=$ stratification adjustment factor. The subscript "Score" indicates that the variable is converted from a measured or calculated value to a score or rating ranging from 0 to 10 based on a set of conversion graphs with established relationships. The study bank height ratio (C), root depth ratio $(\mathrm{E})$, and weighted root density $(\mathrm{G})$ are calculated as follows:

$$
\begin{gathered}
C=\frac{A}{B}(\text { eq. } 2) \\
E=\frac{D}{A}(\text { eq. } 3) \\
G=F^{*} E(\text { eq. } 4)
\end{gathered}
$$

where $A=$ study bank height $(m), B=$ bankfull height $(m), D=\operatorname{root} \operatorname{depth}(m)$, and $F=\operatorname{root}$ density (\%). The bank material adjustment factor $(\mathrm{J})$ accounts for the erodibility of the bank material and ranges from -10 to 10 . It is recommended to assign -10 if the bank is composed of uniform medium to large cobble, assign 5 to 10 for gravel or a composite bank depending on the amount of sand, and assign 10 for sand. The stratification adjustment factor $(\mathrm{K})$ accounts for weak layers of soil in the bank and seepage zones. The stratification adjustment factor ranges from 5-10 depending on the position of unstable layers in relation to the bankfull stage. A 10 would be assigned if the preferentially eroded layer was near the bottom of the bank potentially 
causing mass failure of the material above. The total $\mathrm{BEHI}_{\text {Score }}$ is then converted to a BEHI category (Very Low, Low, Moderate, High, Very High, or Extreme).

\subsubsection{NBS submodel}

The Near Bank Stress (NBS) submodel represents the degree of hydraulic erosion at the bank site. Seven different approaches for estimating the near bank stress are provided in the model, however, we used only one approach:

$$
N B S=\frac{d_{n b}}{d_{b k f}}(\text { eq.5) }
$$

where $d_{n b}=$ near-bank maximum depth from the bankfull elevation (m) and $d_{b k f}=$ mean bankfull depth (m). Similar to BEHI, the NBS is converted from a numerical value to a categorical rating ranging from 1 which belongs to Very Low, to a rating of 6 which belongs to Extreme. A regression model or regional erosion curve is produced for each BEHI category using the NBS rating (1-6) as the predictor variable and measured erosion as the response. These models can then be used to predict erosion at additional sites within the same geomorphic setting by determining the BEHI category and inserting the NBS index value into the appropriate regression model.

\subsubsection{Limitations of the BANCS model}

Currently, regional erosion curves are not available for the geologic and climatic setting of the Appalachian Plateau which includes the Horseshoe Run watershed in Tucker County, West Virginia. Regional erosion curves have been published for streams in Colorado underlain by sedimentary and/or metamorphic geology and for streams in Wyoming, in alpine, glaciated and/or volcanic areas have been developed (Rosgen 2001); however, regional erosion curves for 
the geology and climate more typical of the eastern United States have not yet been validated although regional efforts are underway (W. Harman, R. Starr, personal communication, September 2010, November 2010).

Because of these limitations, we developed a study to determine if the model parameters could be used to predict erosion at our study area. Additionally this study explored the importance of the model parameters at predicting erosion at a restored stream site. The study area was subdivided into an upper and lower reach. Streambanks along the upper $1000 \mathrm{~m}$ of stream (upper reach) appeared to be actively eroding while streambanks along the lower $500 \mathrm{~m}$ (lower reach) were recently stabilized as part of a larger stream restoration effort. Although the BANCS model has been integrated into many stream restoration monitoring efforts, the appropriateness of the model at restored sites has not been tested.

\subsection{Methods}

\subsubsection{Study area}

The Horseshoe Run watershed is located in the Allegheny Mountain section of the Appalachian Plateau Physiographic Province in Tucker County, West Virginia and is approximately 137 square kilometers in size at the project site (Figure 3.1). The project site is $300 \mathrm{~m}$ upstream of the Horseshoe Run confluence with the Cheat River which drains into the Monongahela and then the Ohio River. The Allegheny Mountain section of the province is highly dissected with steep high energy streams flowing into narrow more moderate floodplains. Watershed elevations range from $1115 \mathrm{~m}$ along Backbone Mountain, the eastern ridge of the watershed, to $473 \mathrm{~m}$ near the outlet with an average slope of $46^{\circ}$. The region is characterized by a humid continental climate with average annual rainfall of $1318 \mathrm{~mm}$ and an average annual 
temperature of $9.7^{\circ} \mathrm{C}$. Resistant conglomeritic sandstones of the Pottsville formation underly the ridges and have weathered into bouldery colluvium while a series of strath terraces have been carved into the shales and fine-grained sandstones of the Chemung formation along the Horseshoe Run floodplain (Konsoer 2008; Reger 1923).

The hillslopes and upper portions of the watershed are in various stages of forest stand development due to the historic and current logging in the watershed (Fansler 1962). The narrow floodplain contains a combination of land use practices ranging from intensively grazed to rural residential to forested. Due to the steepness of the hillslopes and the narrowness of the valley, most anthropogenic impacts span the floodplain and in some cases border or intersect the stream (MLRC 2001).

A series of aerial photographs shows that Horseshoe Run has been actively migrating and eroding at significant rates over the past several decades (Canaan Valley Institute 2006; SAMB 2003; USGS 1997). This migration can be attributed to a combination of natural and anthropogenic disturbances. An inherently high bedload and a history of large flooding events combined with the periodic clearing of large swaths of the hillslope and riparian zone for logging, agriculture, and rural development contribute to the erosive nature of the stream. The $1.5 \mathrm{~km}$ long study reach has a mobile gravel substrate.

\subsubsection{Upper reach characterization}

Streambanks in the upper portion of the reach are characterized by a thin layer of cohesive silt loam in the upper bank overlaying layers of soil mixed with gravel and cobble. Floodplain soils through the reach are classified as Gilpin channery silt loams, Philo silt loams or a mixture of alluvial material of the Fluvaquents-Udifluvents complex (Losche and Beverage 
1967). Stream cross sectional area averaged $85 \mathrm{~m}^{2}$ through the upper section with an average width of $83 \mathrm{~m}$ and depth of $1 \mathrm{~m}$. The average bed slope was $0.0059 \mathrm{~m} / \mathrm{m}$ and the substrate ranged from fine gravel to large cobble with a D50 of very coarse gravel measuring $52 \mathrm{~mm}$. Vegetation along the upper portion ranged from dense stands of Platanus occidentalis (American sycamore) to mowed grasses. Betula nigra (river birch), Aesculus flava (yellow buckeye), Rosa multiflora (multiflora rose), Elaeagnus umbellate (autumn olive), and Verbesina alterniflora (wingstem) are other common species found growing adjacent to the stream through this section.

\subsubsection{Lower reach characterization}

Restoration measures were recently undertaken along the lower portion of the project reach (Canaan Valley Institute 2007). The primary goals were to restore stream stability by restoring natural stream dimension and increasing sediment transport, enhancing or reestablishing riparian vegetation, and enhancing aquatic and riparian habitat. The stream channel was narrowed and deepened, and low angle streambanks were constructed with coarse gravel and cobble. Rock and log j-hook structures were installed to redirect water from the outer streambanks (Rosgen 2007), and the banks were seeded and mulched with a native riparian seed mix. Stream cross sectional area averages $47 \mathrm{~m}^{2}$ through the lower section with an average width of $56 \mathrm{~m}$ and depth of $0.9 \mathrm{~m}$. The average bed slope is $0.0044 \mathrm{~m} / \mathrm{m}$ and the substrate ranges from fine gravel to large cobble with a D50 of small cobble measuring $66 \mathrm{~mm}$ through the lower portion of the project reach. 


\subsubsection{Data collection}

Twenty four streambank sites were selected along Horseshoe Run to represent a range of streambank conditions, fifteen sites in the upper reach and nine sites in the lower reach. Two permanent benchmarks, $45 \mathrm{~cm}$ lengths of $1.3 \mathrm{~cm}$ diameter reinforcing bar, were pounded vertically into the ground along a transect perpendicular to the stream at each site beyond the top of the bank from which bank profiles were aligned and measured. One horizontal benchmark, or bank pin, was installed in each bank profile where cohesive soils were present (Coffman 2009; Thorne 1981; U.S. Environmental Protection Agency 1999). Bank profiles were measured using either a laser level or a laser distance finder. The laser level was used to collect bank data through the restored reach where banks have a low slope angle (Harrelson et al. 1994). The laser distance finder was mounted to a stadia rod which was leveled and secured with a tripod to collect bank data through the upper reach where banks were near vertical or overhanging and could not be profiled using laser level techniques.

Baseline bank profile measurements were collected in November 2009. The bank profiles were remeasured in October 2010 to generate annual erosion amounts for each streambank site (Henderson 2006; Pollen 2007; Pollen-Bankhead and Simon 2008; Prosser et al. 2000; Simon et al. 2000). The $\mathrm{x}$ and y bank profile coordinates were imported into ArcMap, a polygon outlining the eroded area was created, and the area of the polygon was calculated (ESRI 1999-2009). Cross section data were collected at each site as well as longitudinal profile data from which channel slope, widths, depths, and radii of curvature were derived. Modified Wolman pebble counts were performed throughout the reach (Harrelson et al. 1994).

A stream gage installed by Canaan Valley Institute approximately $5 \mathrm{~km}$ upstream of the project site on Horseshoe Run collected stage height in 15 minute intervals from November 2009 
through October 2010. Lacking a weather station in the watershed, precipitation data from the Davis 3SE (National Climatic Data Center (NCDC) Coop_ID 462211) and Parsons 1NE (NCDC Coop_ID 466867) weather stations were averaged to approximate precipitation values for the entire watershed. Averaging values from the upper portion of the watershed represented by the Davis station and the mouth of the watershed represented by the Parsons station provided approximate values for the study reach (Figure 3.2). The Davis weather station is located approximately $10 \mathrm{~km}$ east of the watershed at an elevation of $1162 \mathrm{~m}$ and the Parsons station is located approximately $6.5 \mathrm{~km}$ south of the watershed at an elevation of $557 \mathrm{~m}$.

\subsubsection{BANCS model parameterization}

Bank height was calculated by measuring the vertical distance from the bank toe to the top of the bank. Bankfull height was derived by fitting a trend line to the top of bank points along the longitudinal profile and calculating a height using the fitted data. Root depth was measured from the top of the bank to the terminus of the majority of roots. Root density was visually estimated from that portion of the bank considered in the root depth measurement. When bare roots were exposed in three dimensions, the percentage of volume occupied by the roots in three dimensions was estimated. When roots were exposed only on the bank face, the percentage of area occupied by the roots in two dimensions was estimated. When roots were not exposed, percentages were estimated based on the above ground density of vegetation present. Bank angle was measured in ArcMap using the measure angle tool. The angle most likely influencing the gravitational failure of the bank was measured. Surface protection represents the proportion of the bank face that is protected by vegetation, large rocks or other materials that resist hydraulic erosion. We calculated a percent surface protection by measuring the height or length of the bank face that 
was protected, typically by vegetation, and divided this by the total height or length of the bank. A bank material adjustment rating was determined by adding 5 to 10 points to those sites where gravel or a gravel and sand composite matrix was present. A rating of 5 was assigned to all the banks in the lower reach since the banks were constructed out of gravel and cobble with little sand present. The bank material adjustment rating is a subjective rating. We attempted to reduce the amount of subjectivity by producing our own rating system based on the percentage of sand and gravel in the banks using the following classification where the rating is followed by the $\%$ sand and gravel in parenthesis: 5 (0-30\%), $6(30-45 \%), 7$ (45-55\%), 8 (55-70\%), 9 (70-85\%), and $10(85-100 \%)$. Percentages were determined based on a textural classification of soils in the laboratory (ASTM 1988). A stratification adjustment factor was assigned for those banks in the upper reach that were stratified. Similar to the revisions made to the bank material adjustment, we devised a classification system for the stratification adjustment ratings as follows: 5 for those banks with stratification but without preferential erosion, 8 for those banks exhibiting any stratified preferential erosion, and 10 for those banks with preferential erosion in the lower stratified layers and/or with preferential erosion below the root zone. Banks in the lower reach were not stratified and therefore assigned a rating of 0 . The minimum, mean, and maximum values for the collected model parameters for the upper and lower reach are listed in Table 3.1.

\subsubsection{Statistical analysis}

\subsubsection{Differences between reaches}

We used multivariate analysis of variance (MANOVA) to assess whether or not the upper and lower reach differed in terms of stream cross sectional area, width, mean and maximum depths, slopes, median particle size and radius of curvature based on data collected at each bank 
site. Principle components analysis (PCA) was used to characterize the streambank sites in terms of the BANCS model parameters. The reach category (upper/lower) was overlain on the PCA plot to determine if the upper and lower reaches differed in terms of streambank characteristics.

\subsubsection{Grouping analysis}

The BANCS model groups streambanks into 36 categories based on the BEHI and NBS scores. We did not have an adequate number of banks in unique categories to determine if erosion differed between these categories. In lieu of this, we used cluster analysis to establish groups of streambanks and then compared the observed erosion between these groups. Cluster analysis using the Ward agglomeration method was used on the sites with all of the BEHI and the NBS parameters. Cluster analysis was also used on sites in the upper reach since those sites were more representative of natural streambank conditions. The BEHI and NBS data were log transformed to meet normality assumptions where appropriate, scaled and centered, and then a Euclidean distance matrix was generated from this data to be used as input to the cluster analysis. Analysis of variance (ANOVA) was then used to determine if erosion differed between the cluster groups

\subsubsection{Streambank erosion prediction parameters}

All-possible-subset regression, was used to identify the subset of BANCS model parameters that could best predict erosion and explore the relative importance of each model parameter. All-possible-subset regression is an alternative to stepwise regression and was used to avoid the presumption that there is a single best subset and to assess the importance of the 
different explanatory variables (Hill and Lewicki 2006). Parsimonious models with multiple $\mathrm{R}^{2}$ values of $>0.8$ were selected for the relative importance assessment. Relative importance measures were calculated using the following methods: average sequential sums of squares over all orderings of regressors, Lindeman, Merenda, and Gold method (lmg) (Lindeman et al. 1980); comparison of what each regressor was able to explain in addition to all other variables (last); comparison of each regressor alone (first); and comparison of the importance to a variable in proportion to the product of its standardized regression coefficient (Pratt 1987) (Gromping 2006). Data were $\log _{10}$ transformed where appropriate to meet normality assumptions. All statistical analyses were performed in the R 2.12.1 language and environment (R Development Core Team, Vienna, Austria).

\subsection{Results}

\subsubsection{Streamflow, precipitation, and measured erosion}

Total precipitation averaged between the two stations was $1240 \mathrm{~mm}$ for the study period with greater than $5 \mathrm{~m}$ of total snowfall. The highest streamflow events occurred in the winter months between December and April from a combination of rainfall, snowmelt, and rain on snow events. Long term data was unavailable for the CVI gage, however the nearby USGS Cheat River near Parsons, WV (03069500) gaging station had a historic record and indicated that the January high flow event had a recurrence interval of approximately 1.7 years and the March flow event had a recurrence interval of approximately 1.5 years. The December high flow on Horseshoe Run was a localized event and did not have corresponding elevated discharge on the Cheat River. 
The measured erosion at all the streambank sites ranged from $0.02 \mathrm{~m}^{2}$ to $5.33 \mathrm{~m}^{2}$ (mean $1.03 \mathrm{~m}^{2}$ and median $0.55 \mathrm{~m}^{2}$ ) (Figure 3.3). Because data were collected along a cross sectional transect, only two dimensional erosion data were calculated. A third dimension measured along the length of the bank would have been required to generate the volume of erosion. The upper and lower section did not appear to differ in the area of erosion (Welsch two sample t-test pvalue $=0.82)$. However, the modified geomorphology of the lower reach and the different streambank characteristics may lead to different erosional processes and responses between the two reaches.

\subsubsection{Geomorphic differences between reaches}

MANOVA was used to determine if the geomorphology of the stream in the upper section was statistically different than the geomorphology of the stream in the lower, recently restored section. Cross sectional area, width, mean and maximum depths, bed slope, median particle size, and radius of curvature were incorporated into the MANOVA. Cross sectional area, width, and median particle size were $\log _{10}$ transformed prior to the MANOVA. The geomorphology of the stream differed statistically among the upper and lower reaches $(p<0.001)$.

Cross sectional area, width, median particle size, and radius of curvature all differed statistically among the sections (Table 3.2). The restored reach had a mean width of $56 \mathrm{~m}$ and a mean cross sectional area of $47 \mathrm{~m}^{2}$. These cross sections were narrower and had a smaller cross sectional area than those through the upper reach that had a mean width and area of $83 \mathrm{~m}$ and $85 \mathrm{~m}^{2}$ respectively. The median particle size also differed between the upper and lower reach with mean diameters of $52 \mathrm{~mm}$ and $66 \mathrm{~mm}$ respectively. Radii of curvature were smaller through the restored reach with a smaller range of values, though these values were more difficult to compare 
because neighboring sites around the same meander bend had the same radii of curvature and therefore were not unique to a site. Figure 3.4 depicts a series of boxplots of these differing variables.

A PCA on the streambank and near bank characteristics also revealed a difference between the upper and lower groups of streambanks. PCA extracted three dimensions (Eigen values $>1)$ of variance $(61 \%$ of total) (Table 3.3$)$. The $1^{\text {st }}$ principle component axis, which was controlled by bank angle and bank material, differentiated the upper and lower sites (Figure 3.5). The $2^{\text {nd }}$ principle component axis separated streambank sites in the upper reach based on vegetative characteristics. The third dimension was controlled by surface protection and near bank depth ratios.

\subsubsection{Grouping analysis}

The cluster analysis divided the upper streambanks into three groups: a highly stratified, densely vegetated group (Group 1), a sparsely vegetated group (Group 2), and a group with intermediate vegetation and low bank angles (Group 3). ANOVA revealed that erosion differed between the cluster groups at the 0.1 significance level (p-Value 0.08 ). Boxplots of transformed erosion by cluster groups indicated that the intermediate vegetation, low bank angle group (Group 3) was characterized by lower erosion amounts than the remaining sites (Figure 3.6). This group of streambanks had uniform bank composition, high surface protection, low bank angles, and intermediate rooting depth and rooting density values compared to the remaining sites. 


\subsubsection{Predicted streambank erosion}

Due to differences between sites in the upper and lower reaches, separate regression analyses were performed on these two groups of streambanks. The most parsimonious model for the upper reach included root depth ratio, weighted root density, bank angle, bank material, and near bank depth ratio with bank angle having the greatest relative importance. Best fit models for each subset size as well as the relative importance of each variable are shown in Figures 3.7 and 3.8. The most parsimonious model with a multiple $\mathrm{R}^{2}$ values of $>0.8$ was selected for the relative importance plots. The most parsimonious model for the lower reach included bank height ratio, root depth ratio, weighted root density, and bank angle, with bank angle having the greatest relative importance for most methods. Coefficients of model estimates are shown in Table 3.4.

\subsection{Discussion}

\subsubsection{Differences between reaches}

\subsubsection{Morphology}

The recent restoration activities in the lower reach altered the stream morphology and streambank characteristics from those in the upper reach. Cross sectional area and width were significantly smaller in the lower reach, while the mean and maximum depths did not vary between reaches. The similarity in depths is likely due to the spatial distribution of cross sections/streambanks. For example, a comparison of pool depths or riffle depths between the two reaches might have provided different results. The reduction in cross sectional area increased the boundary shear stress against the bed and banks for a given flow. Fluvial erosion is 
typically calculated using an excess shear stress approach in which an increase in boundary shear stress would indicate an increase in fluvial erosion (Simon 2000). The larger median particle diameter in the lower reach may have been a result of this potential increase in fluvial erosion suggested by the excess shear stress approach, indicating that smaller bedload particles were being transported through the lower reach but were continuing to deposit in the upper reach and cause aggradation. The radii of curvature were smaller in the lower reach than the upper reach. Although radii of curvature were not altered during restoration, the smaller radii in the lower reach could have increased fluvial erosion by increasing the secondary flow in the near bank region (Johannesson and Parker 1989; Papanicolaou et al. 2007). We explored streambanks from the upper and lower reach separately in subsequent analysis to determine if the geomorphic differences might influence streambank erosion processes and predictions.

\subsubsection{Streambank characteristics}

The major differences in the BANCS model parameters between the reaches were the bank angle and bank material parameters which are to be expected because low angle banks in the lower reach were recently reconstructed with the gravel and cobble material present in the stream vicinity. Vegetative characteristics separated the sites as well and were also differentiating factors in the cluster analysis of the upper streambank sites.

\subsubsection{Grouping analysis}

The group of streambanks with uniform bank composition, high surface protection, low bank angles, and intermediate rooting depth and rooting density had lower erosion compared to the remaining sites in the upper reach. Banks with uniform composition, high surface protection, 
and low bank angles are typically believed to have a lower susceptibility to erosion; however, the intermediate vegetation values were a little less clear. Vegetation has been shown to have both positive and negative influences on bank stability (Simon and Collison 2002; Wallick et al. 2006); a negative influence was evident at one site in the project reach. The site with the highest

erosion $\left(5.33 \mathrm{~m}^{2}\right)$ had a large tree about a meter beyond the top of the bank. Erosion caused the bank to retreat back to the tree and removed the entire root network and underlying streambank when it failed. A streambank without any vegetation may be equally as vulnerable since there is no protection from surface erosion and no added cohesion due to roots (Abernathy and Rutherfurd 1998; Wynn and Mostaghimi 2006). Studies have found that a mix of vegetation with varying sizes of root classes or grass and shrub species with high densities but low surcharge, may provide the best protection, and the intermediate classes of vegetation identified in this study may support these findings (Simon and Collison 2002; Wynn and Mostaghimi 2006).

\subsubsection{Streambank erosion prediction models}

\subsubsection{Erosion in the upper reach}

Streambank erosion in the upper section was influenced primarily by the angle of the bank, the amount of sand and gravel present in the bank, and the hydraulic stress in the near bank region, with the angle of the bank having the highest relative importance of all the variables. Bank angle is a central parameter for all mechanistic streambank erosion models that represents both the driving and resisting forces of bank stability equations (Abernathy and Rutherfurd 1998; Chu-Agor et al. 2008; Micheli and Kirchner 2002; Pollen 2007; Simon and Collison 2002; Simon et al. 2000; Simon et al. 2009). The composition and associated cohesion of the bank 
material is also central to mechanistic streambank erosion models and has been identified in several empirical erosion prediction models (Clark and Wynn 2007; Julian and Torres 2006; Wynn and Mostaghimi 2006). In our study, near bank stress was represented by the ratio of the near bank maximum depth to the average depth of the cross section. This ratio, as with many near bank stress estimation techniques, was a gross idealization of the hydraulic influences on erosion (Rinaldi et al. 2008); however, it appeared to provide some perspective as to the fluvial entrainment of bank material at individual sites. Accounting for curvature and secondary flow forces may have improved the estimation of near bank stress assessments (Johannesson and Parker 1989; Papanicolaou et al. 2007; Wallick et al. 2006), but this was not assessed in this study. Vegetation had the next highest relative importance based on the lmg, first and last relative importance methods, while streambank height and surface protection did not appear to have an important influence on the susceptibility to erosion. Erosion was detected across the entire range of bank height ratios. Three stormflow events were experienced during the study period, one of which generated above bank flows at some sites (Figure 3.2). A couple additional smaller stormflow events raised water levels in the stream. Shorter banks have a greater proportion of their banks inundated during low and moderate flows, whereas taller banks tend to be more susceptible to gravitational or mass failure. However, it may take time for this instability to manifest (Lawler et al. 1997; Simon and Collison 2002). If the study period were longer and/or experienced larger flows, bank height might have become a more important factor. Surface protection through the upper reach consisted mostly of blocks of failed bank material with grasses attached. Failed blocks of bank material can provide some protection from fluvial entrainment during low flows; however, the large flows experienced during the study period most likely entrained this failed material. 


\subsubsection{Erosion in the lower reach}

Streambank erosion in the lower reach was dominated by a shallow type failure of bank material that appeared to be influenced most directly by the angle of the bank (Hey et al. 1991). In the upper section, higher bank angles had higher erosion, but in the lower section the reverse appeared to be true. Banks in the lower section were constructed with non-cohesive coarse gravel and small cobble, which tended to be easily entrained when sufficient flow was present (Thorne 1982). The lower angled streambanks experiencing more erosion was somewhat surprising but is likely a result of the increased bank width at these sites. The wider shallower banks extended further into the streambed and enabled the detection of more fluvial entrainment. The importance of the vegetation characteristics in predicting erosion in the lower reach was more influenced by the density of vegetation rather than the rooting depth. The importance of root density has been shown in a number of studies (Abernathy and Rutherford 2001; Micheli and Kirchner 2002; Piercy and Wynn 2008; Pollen 2007) even for herbaceous ground cover (Wynn and Mostaghimi 2006) which is the first vegetation to establish at many restoration sites. Near bank stress was not identified as an important factor for predicting erosion at the lower reach. Restoration efforts attempted to reduce the stress in the near bank region by excavating the thalweg in the center of the channel and by redirecting the flow toward the center of the channel around the meander bends with instream structures. Similar instream structures were found to maintain this restored depth and flow pattern (Bhuiyan et al. 2009) thereby maintaining reduced shear stress against the banks and decreasing erosion potential. When these structures are redirecting flow away from the streambanks, the near bank stress may be low and may not aid in predicting erosion. 


\subsection{Conclusion}

Our results suggest that the input parameters for the BANCS model may be used to explain the susceptibility of a streambank to erosion. However, careful consideration needs to be given when using streambank and near bank characteristics to predict relative erosion on sections of the same stream with different morphology and potentially different dominant erosional processes. With regard to our initial question, we found that the recent restoration activities in the lower reach altered the stream morphology and streambank characteristics from those in the upper reach. Because of this difference, streambanks in the two reaches were analyzed separately in the exploration of subsequent objectives.

To meet our next objective, we used cluster analysis to establish groups of streambanks and then compared the observed erosion between these groups. When the streambank parameters were used to group sites independently of erosion, a group of streambanks with moderate rooting depths and densities, low bank angles, and surface protection emerged. This group experienced the least amount of erosion. This finding encourages the continuation of streambank stabilization practices that involve reducing bank angles, installing erosion control fabric, and planting a variety of vegetation. A variety of vegetation types with a wide distribution of root sizes and depths may provide more stability than larger vegetation with deeper, denser root networks. This may be particular true for incised streams with high hydraulic erosion at the bank toe where the surcharge of large trees may outweigh the stabilizing effects of vegetation.

Lastly, the regression analyses revealed that the different reach morphologies and streambank characteristics between the upper and lower reach did have implications for 
streambank erosion processes and prediction models. The inverse correlations with erosion and bank angles between the upper and lower reach was a good example of the need to separate reaches along the same river. Higher bank angles in the upper reach were more susceptible to gravitational failure while lower bank angles in the lower reach were more susceptible to fluvial erosion. Additionally, not all parameters should necessarily be weighted equally at all sites. In the BANCS model, measured or estimated BEHI variables are converted to index values based on a series of graphs and the index values are added together for a total index score. The graphs provide some indication as to the influence of the measured value to the overall erosion but our study found that this might not be sufficient. For example, we showed that for non-cohesive restored banks that were vulnerable to fluvial erosion, bank angle, bank height, and vegetation parameters were needed to predict susceptibility to erosion. Alternatively, for cohesive banks with non-cohesive bank toe material that were vulnerable to fluvial erosion and mass failure, bank angle, bank material, and near bank depth ratios with an emphasis on bank angle were sufficient parameters to predict susceptibility.

The BANCS model provides a solid framework for a comparable, transferable erosion prediction model that could be easily and rapidly applied at a watershed scale. However, we suggest the following improvements to the model: regional relationships for converting the measured ratios to index values should be refined as the regional erosion curves are developed, sets of weighting coefficients based on dominant erosion processes should be explored, and the potentially negative effects of vegetation should be incorporated into the model if present at a site. 


\section{Literature Cited}

Abernathy, B., and Rutherford, I. (2001). "The distribution and strength of riparian tree roots in relation to riverbank reinforcement." Hydrological Processes, 15, 63-79.

Abernathy, B., and Rutherfurd, I. (1998). "Where along a river's length will vegetation most effectively stabilise stream banks?" Geomorphology, 23, 55-75.

ASTM. (1988). Annual Book of ASTM Standards, American society for testing and materials, Philadelphia.

Bhuiyan, F., Hey, R. D., and Wormleaton, P. R. (2009). "Effects of vanes and w-weirs on sediment transport in meandering channels." Journal of Hydraulic Engineering, 135(5), 339-349.

Canaan Valley Institute. (2007). "Horseshoe Run Natural Stream Restoration - Phase III (Knotts Property)." Permit Number 2007-232, US Army Corps of Engineers, Pittsburgh, PA.

Chen, Y., Bhatia, S. K., Buchanan, J., DeKoskie, D., and VanSchaack, R. (2005). "Effectiveness of Stream Restoration in Reducing Stream Bank Erosion: The Case of Batavia Kill Stream Restoration Projects, New York." 
Chu-Agor, M. L., Fox, G. A., Cancienne, R. M., and Wilson, G. V. (2008). "Seepage caused tension failures and erosion undercutting of hillslopes." Journal of Hydrology, 359, 247259.

Clark, L. A., and Wynn, T. M. (2007). "Methods for determining streambank critical shear stress and soil erodibility: Implications for erosion rate predictions." Transactions of the ASABE, 50(1), 95-106.

Coffman, D. K. (2009). "Streambank erosion assessment in non-cohesive channels using erosion pins and submerged jet testing, Dallas/Fort Worth, Texas," Master of Science, Baylor University.

ESRI. (1999-2009). "ArcMap." ArcGIS, Redlands, CA.

Evans, D. J., Gibson, C. E., and Rossell, R. S. (2006). "Sediment loads and sources in heavily modified Irish catchments: A move towards informed management strategies." Geomorphology, 79, 93-113.

Fansler, H. F. (1962). History of Tucker County, West Virginia, McClain Printing Company, Parsons, WV.

Gromping, U. (2006). "Relative importance for linear regression in R: The package relaimpo." Journal of Statistical Software, 17(1), 27. 
Harrelson, C. C., Rawlins, C. L., and Potyondy, J. P. (1994). "Stream Channel Reference Sites: An Illustrated Guide to Field Techniques." RM-245, USDA Forest Service, Rocky Mountain Forest and Range Experiment Station, Fort Collins, CO.

Henderson, M. B. (2006). "Changes in streambank erodibility and critical shear stress due to surface subaerial processes," Master of Science, Virginia Polytechnical Institute and State University, Blacksburg, VA.

Hey, R. D., Heritage, G. L., Tovey, N. K., Boar, R. R., Grant, N., and Turner, R. K. (1991). "Streambank protection in England and Wales." R\&D Note 22, National Rivers Authority, London.

Hill, T., and Lewicki, R. (2006). Statistics: Methods and applications: A comprehensive reference for science, industry, and data mining, StatSoft Inc., Tulsa, OK.

Johannesson, H., and Parker, G. (1989). "Velocity redistribution in meandering rivers." Journal of Hydraulic Engineering, 115(8), 1019-1039.

Julian, J. P., and Torres, R. (2006). "Hydraulic erosion of cohesive riverbanks." Geomorphology, 76, 193-206.

Konsoer, K. M. (2008). "LiDAR, GIS, and multivariate statistical analysis to assess landslide risk, Horseshoe Run watershed, West Virginia," Master of Science, West Virginia University, Morgantown, WV. 
Lawler, D. M., Grove, J. R., Couperthwaite, J. S., and Leeks, G. J. L. (1999). "Downstream change in river bank erosion rates in the Swale-Ouse system, northern England." Hydrological Processes, 13(7), 977-992.

Lawler, D. M., Thorne, C. R., and Hooke, J. M. (1997). "Bank erosion and instability." Applied Fluvial Geomorphology for River Engineering and Management, C. R. Thorne, R. D. Hey, and M. D. Newsom, eds., John Wiley \& Sons Ltd, West Sussex, England.

Lindeman, R. H., Merenda, P. F., and Gold, R. Z. (1980). Introduction to Bivariate and Multivariate Analysis, Scott Foresman and Co, Glenview, IL.

Losche, C. K., and Beverage, W. W. (1967). "Soil survey of Tucker County and part of Northern Randolph County." United States Department of Agriculture, Soil Conservation Service and Forest Servuce, In cooperation with West Virginia Agricultural Experiment Station.

Magner, J. A., and Brooks, K. N. (2008). "Predicting stream channel erosion in the lacustrine core of the upper Nemadji River, Minnesota (USA) using stream geomorphology metrics." Environmental Geology, 54, 1423-1434.

Micheli, E. R., and Kirchner, J. W. (2002). "Effects of wet meadow riparian vegetation on streambank erosion. 2. Measurements of vegetated bank strength and consequences for failure mechanics." Earth Surface Processes and Landforms, 27, 687-697. 
Papanicolaou, A. N., Elhakeem, M., and Hilldale, R. (2007). "Secondary current effects on cohesive river bank erosion." Water Resources Research, 43, W12418.

Piercy, C., and Wynn, T. (2008). "Predicting root density in streambanks." Journal of the American Water Resources Association, 44(2), 496-508.

Pizzuto, J. (2009). "An empirical model of event scale cohesive bank profile evolution." Earth Surface Processes and Landforms, 34, 1234-1244.

Pollen, N. (2007). "Temporal and spatial variability in root reinforcement of streambanks: Accounting for soil shear stength and moisture." Catena, 69, 197-205.

Pollen-Bankhead, N., and Simon, A. (2008). "Enhanced application of root-reinforcement algorithms for bank-stability modeling." Earth Surface Processes and Landforms, 34, 471-480.

Pratt, J. W. (1987). Dividing the indivisible: Using simple symmetry to partition variance explained, University of Tampere.

Prosser, I. P., Hughes, A. O., and Rutherford, I. D. (2000). "Bank erosion of an incised upland channel by subaerial processes: Tasmania, Australia." Earth Surface Processes and Landforms, 25(10), 1085-1101.

Reger, D. B. (1923). "County Reports, Tucker County." West Virginia Geologic Survey. 
Rinaldi, M., Mengoni, B., Luppi, L., Darby, S. E., and Mosselman, E. (2008). "Numerical simulation of hydrodynamics and bank erosion in a river bend." Water Resources Research, 44(W09428), doi:10.1029/2008WR007008.

Rosgen, D. (1996). "Field Survey Procedures for Characterization of River Morphology."

Rosgen, D. "A practical method of computing streambank erosion rate." Proceeding of the seventh Federal Interagency Sedimentation Conference, Reno, NV, II-9-II-15.

Rosgen, D. (2006). Watershed Assessment of River Stability and Sediment Supply (WARSSS), Wildland Hydrology, Fort Collins, CO.

Rosgen, D. (2007). "Chapter 11: Rosgen geomorphic channel design." Part 654 Stream Restoration Design National Engineering Handbook, United States Department of Agriculture, Natural Resouce Conservation Service.

Rosgen, D. L. (1973). "The use of color infrared photography for the determination of sediment production." Fluvial Processes and Sedimentation, Canadian National Research Council, Edmonton, Alberta, Canada, 381-402.

Rosgen, D. L. (1976). "The use of color infrared photography for the determination of suspended sediment concentrations and source areas." Proceedings of the third inter-agency sediment conference, Water Resources Council, Chap. 7, 30-42. 
Sekely, A. C., Mulla, D. J., and Bauer, D. W. (2002). "Streambank slumping and its contribution to the phosphorous and suspended sediment loads of the Blue Earth River, Minnesota." Journal of Soil and Water Conservation, 57, 243-250.

Simon, A., and Collison, A. (2002). "Quantifying the mechanical and hydrologic effects of riparian vegetation on streambank stability." Earth Surface Processes and Landforms, 27, $527-546$.

Simon, A., Curini, A., Darby, S., and Langendoen, E. (2000). "Bank and near-bank procsses in an incised channel." Geomorphology, 35, 193-217.

Simon, A., Pollen-Bankhead, N., Mahacek, V., and Langendoen, E. (2009). "Quantifying reductions of mass-failure frequency and sediment loadings from streambanks using toe protection and other means: Lake Tahoe, United States." Journal of the American Water Resources Association, 45(1), 170-186.

Simon, A., and Rinaldi, M. (2006). "Disturbance, stream incision, and channel evolution: The roles of excess transport capacity and boundary materials in controlling channel response." Geomorphology, 79(3-4), 361-383.

Thorne, C. R. "Field measurements of rates of bank erosion and bank material strength." Proceedings of the Florence Symposium. 
Thorne, C. R. (1982). "Processes and mechanisms of river bank erosion." Gravel-bed rivers, R. D. Hey, J. C. Bathurst, and C. R. THorne, eds., Wiley, Chichester, 227-259.

Trimble, S. (1997). "Contribution of stream channel erosion to sediment yield from an urbanizing watershed." Science, 278(5342), 1442-1444.

U.S. Environmental Protection Agency. (1999). "Protocol for developing sediment TMDLs." EPA 841-B-99-004 Office of Water (4503FF), United States Environmental Protection Agency, Washington D.C. 132 pp.

Wallick, J. R., Lancaster, S. T., and Bolte, J. P. (2006). "Determination of bank erodibility for natural and anthropogenic bank materials using a model of lateral migration and observed erosion along the Willamette River, Oregon, USA." River Research and Applications, 22, 631-649.

Wynn, T., and Mostaghimi, S. (2006). "The effects of vegetation and soil type on streambank erosion, southwestern Virginia, USA." Journal of the American Water Resources Association, 42(1), 69-82. 
Figure 3.1: The study area is located near the outlet of the Horseshoe Run watershed which lies within the Allegheny Mountain Section of the Appalachian Plataea physiographic province, Tucker County, WV.

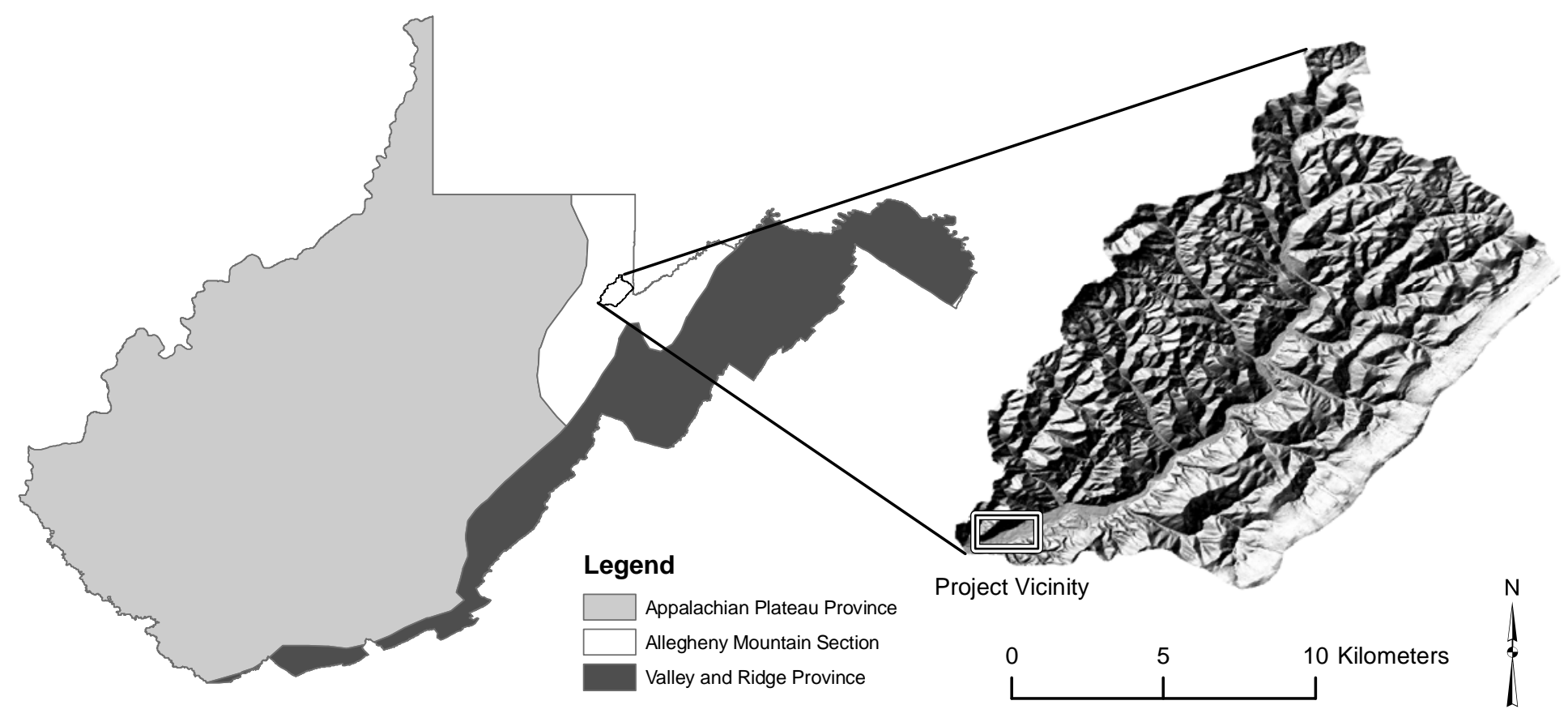


Table 3.1: BANCS model input parameters with associated measurement units. X's indicate whether the parameter was measured based on data collected in the field or estimated/derived using best professional judgement. Minimum, mean, and maximum values for the upper and lower reach are also provided for each parameter.

\begin{tabular}{|c|c|c|c|c|c|c|c|c|c|}
\hline \multirow[t]{2}{*}{ Parameter } & \multirow[t]{2}{*}{ Unit } & \multirow[t]{2}{*}{ Measured } & \multirow[t]{2}{*}{$\begin{array}{c}\text { Esimated } \\
\text { Derived }\end{array}$} & \multicolumn{3}{|c|}{ Upper Reach } & \multicolumn{3}{|c|}{ Lower Reach } \\
\hline & & & & Min & $\mathrm{Mn}$ & Max & Min & $\mathrm{Mn}$ & Max \\
\hline \multicolumn{10}{|l|}{ Bank Erosion Hazard Index (BEHI) } \\
\hline Study bank height ratio & & & & 0.52 & 1.11 & 1.75 & 0.92 & 1.14 & 1.40 \\
\hline Bankfull height & $\mathrm{m}$ & & $x$ & 0.83 & 1.48 & 2.03 & 1.43 & 1.76 & 2.37 \\
\hline Bank height & $\mathrm{m}$ & $\mathrm{x}$ & & 1.03 & 1.38 & 1.60 & 1.14 & 1.56 & 2.05 \\
\hline Root depth ratio & & & & 0.02 & 0.27 & 0.72 & 0.06 & 0.12 & 0.21 \\
\hline Root depth & $\mathrm{m}$ & $x$ & & 0.03 & 0.39 & 1.22 & 0.15 & 0.20 & 0.30 \\
\hline Bank height & $\mathrm{m}$ & $\mathrm{x}$ & & 0.83 & 1.48 & 2.03 & 1.43 & 1.76 & 2.37 \\
\hline Weighted root density & & & & 0.17 & 4.95 & 14.44 & 1.29 & 3.58 & 10.66 \\
\hline Root density & $\%$ & & $x$ & 5.00 & 15.20 & 30.00 & 15.00 & 28.89 & 50.00 \\
\hline Root depth ratio & & $x$ & & 0.02 & 0.27 & 0.72 & 0.06 & 0.12 & 0.21 \\
\hline Bank angle & degrees & $x$ & & 30.00 & 66.43 & 136.00 & 10.00 & 17.67 & 24.00 \\
\hline Surface protection & $\%$ & $x$ & & 0.00 & 19.20 & 72.00 & 0.00 & 40.00 & 50.00 \\
\hline Bank material adjustment & & & $x$ & 5.00 & 7.60 & 9.00 & 5.00 & 5.00 & 5.00 \\
\hline Stratification adjustment & & & $x$ & 0.00 & 6.00 & 10.00 & 0.00 & 0.00 & 0.00 \\
\hline \multicolumn{10}{|l|}{ Near Bank Stress Index (NBS) } \\
\hline Depth ratio & & & & 0.98 & 1.47 & 2.08 & 1.00 & 2.39 & 3.68 \\
\hline Near bank max depth & $\mathrm{m}$ & $x$ & & 0.98 & 1.76 & 2.42 & 0.51 & 1.99 & 2.47 \\
\hline Mean depth & $\mathrm{m}$ & $x$ & & 0.77 & 1.24 & 1.88 & 0.63 & 0.90 & 1.30 \\
\hline
\end{tabular}


Figure 3.2: Averaged precipitation from the Davis 3SE and Parsons 1NE National Climate Data Center weather stations and streamflow stage from the Canaan Valley Institute streamgage for the study period. Solid horizontal line represents the stage required for flow to overtop banks for the average bank height through the study area. Lower dotted line represents the stage required to overtop the shortest study bank while upper dotted line represents the stage required to overtop the tallest study bank. Gaps in streamflow represent missing data.
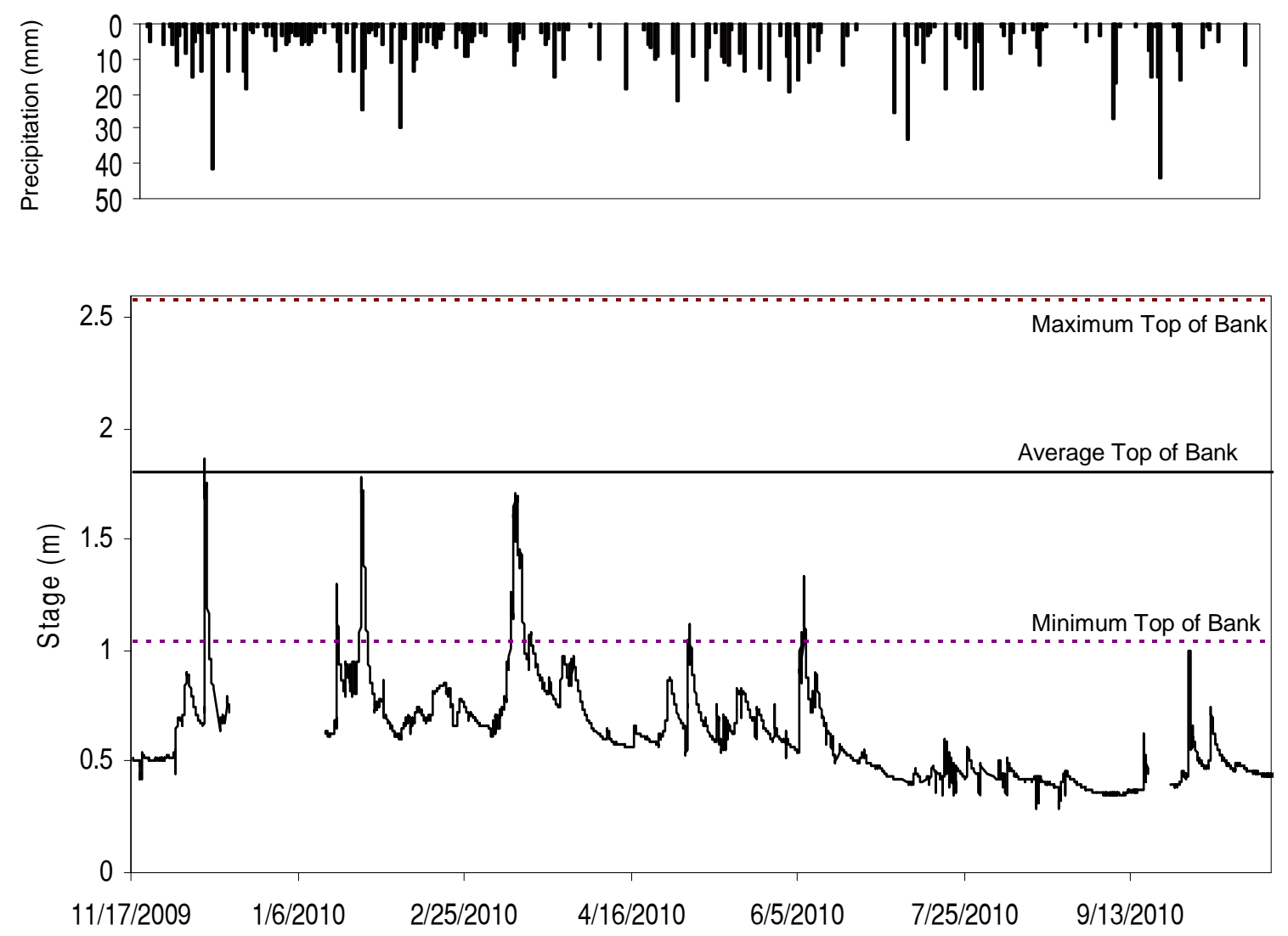
Figure 3.3: Barplot of measured erosion $\left(\mathrm{m}^{2}\right)$ at the streambank sites in order from upstream to downstream.

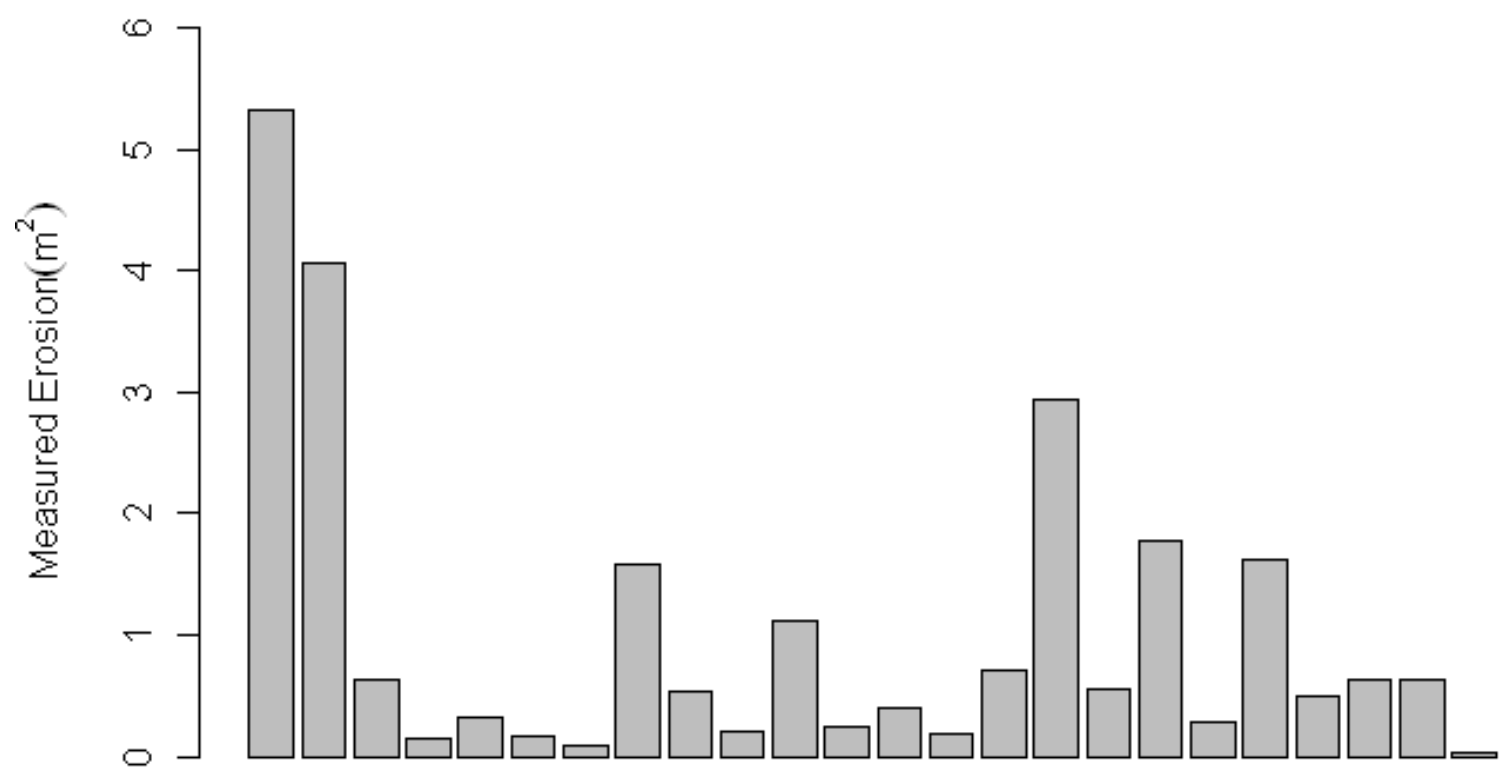

Streambank sites from upstream to downstream 
Table 3.2: MANOVA results indicating that cross sectional area, cross sectional width, median particle size (D50) and radius of curvature are significantly different between the upper and lower reach.

\begin{tabular}{lcc} 
Variables & Transformation & p-Value \\
\hline All variables & & $1 . \mathrm{E}-04^{\star * *}$ \\
Individual variables & Transformation & $\mathbf{p}$-Value \\
\hline Cross sectional area & $\log$ & $0.05^{*}$ \\
Cross sectional width & $\log$ & $0.01^{*}$ \\
Cross sectional mean depth & & 0.28 \\
Cross sectional max depth & & 0.26 \\
Streambed slope & & 0.11 \\
D50 & log & $0.01^{\star *}$ \\
Radius of Curvature & & $8 . \mathrm{E}-04^{\star * *}$ \\
\hline
\end{tabular}

Signif. codes: 0 ‘***’ 0.001 '**’ 0.01 '*’ 0.05 '.' 0.1 “ ' 1 
Figure 3.4: Boxplots of statistically significant parameters for the lower and upper reaches as determined by the MANOVA: (A) Log of Cross sectional Area (B) Log of Cross sectional width (C) Log of D50 (D) Radius of curvature.
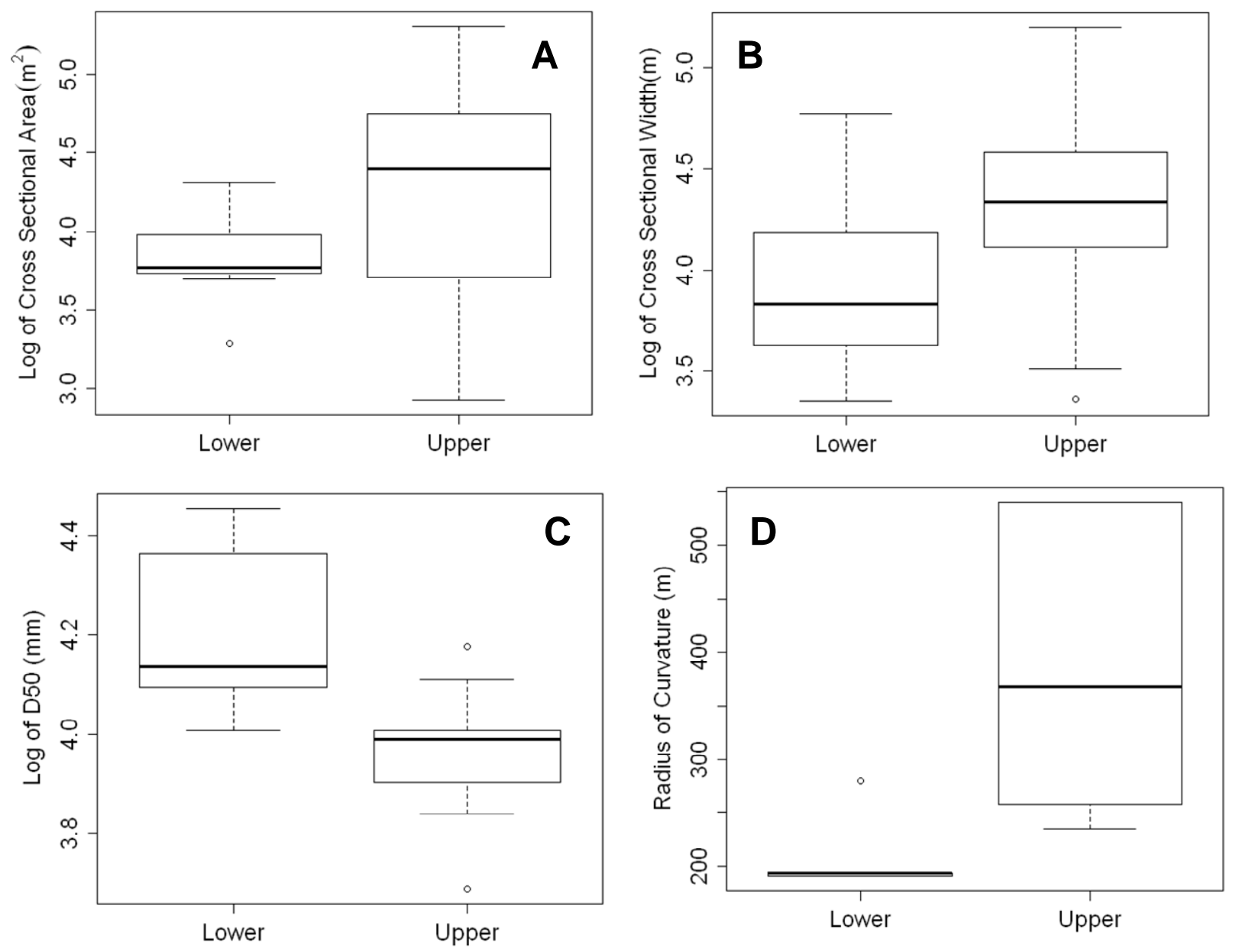
Table 3.3: PCA results with principle components with eigen values greater than $>1$. Only those variable loadings $>|0.4|$ are shown. PC1 is controlled by bank angle, bank material, and stratification. PC2 is controlled by the vegetation parameters. PC 3 is controlled by surface protection and near bank depth ratios.

\begin{tabular}{lccc} 
& PC1 & PC2 & PC3 \\
\hline Standard Deviation & 1.74 & 1.44 & 1.04 \\
Proportion of Variance & $25 \%$ & $21 \%$ & $15 \%$ \\
Cumulative Variance & $25 \%$ & $46 \%$ & $61 \%$ \\
Eigen Values & 3.04 & 2.07 & 1.08 \\
Variable Loadings & & & \\
\hline Bank height ratio & - & - & - \\
*Root depth ratio & - & 0.59 & - \\
*Weighted root density & - & 0.65 & - \\
*Bank angle & 0.52 & - & - \\
Surface protection & - & - & 0.60 \\
Bank material adjustment & 0.43 & - & - \\
Stratification adjustment & 0.55 & - & - \\
*Near bank depth ratio & - & - & -0.68 \\
\hline
\end{tabular}

* log transformed 
Figure 3.5: Scatterplot of streambank characteristic principle component scores 1 and 2 where observations are coded by location: upper reach (Up) or lower reach (Low). Separation between the upper and lower reach is evident on the PC1 axis controlled by bank angle, bank material, and stratification. Separation within the upper reach sites is evident on PC2 controlled by the vegetation parameters.

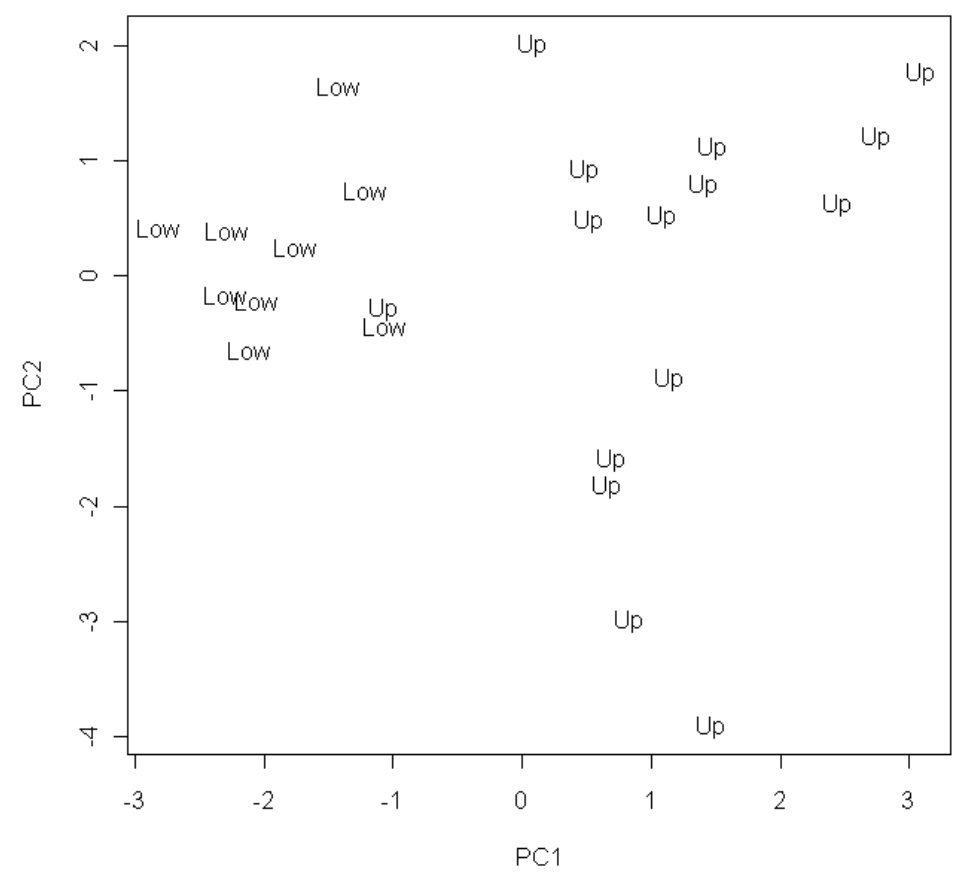


Figure 3.6: Cluster analysis using the ward agglomeration method identified three groups of streambanks. Boxplots of log(erosion) values indicate that Group 3 had lower erosion amounts than the remaining streambank sites. Streambanks in Group 3 were characterized by low bank angles, some surface protection, and intermediate rooting depth and density values.

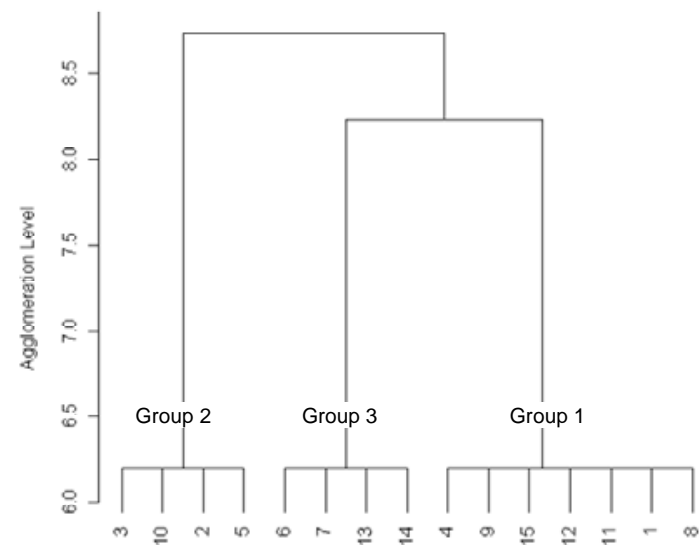

Streambank Sites




Figure 3. 7: All-possible-subset regression was used to identify the subset of BANCS model parameters that could best predict erosion. The best model determined for each subset size in the all subset regression analysis for the upper reach is represented on the left. Bank angle had the highest correlation with erosion when each parameter was correlated with erosion separately, explaining $58 \%$ of the variation in erosion $\left(R^{2}\right)$. The best model for each pair of parameters included bank angle and bank material adjustment, explaining $66 \%$ of the variation in erosion. The model including bank angle, bank material adjustment, near bank stress, and the vegetation parameters was selected as the most parsimonious. Relative importance metric plots were plotted for this model. Relative importance measures were calculated using the following methods: average sequential sums of squares over all orderings of regressors, Lindeman, Merenda, and Gold method (lmg) (Lindeman et al. 1980); comparison of what each regressor was able to explain in addition to all other variables (last); comparison of each regressor alone (first); and comparison of the importance to a variable in proportion to the product of its standardized regression coefficient (Pratt 1987). These metrics all indicate that bank angle was the most important variable. * indicates the parameter was log base 10 transformed.
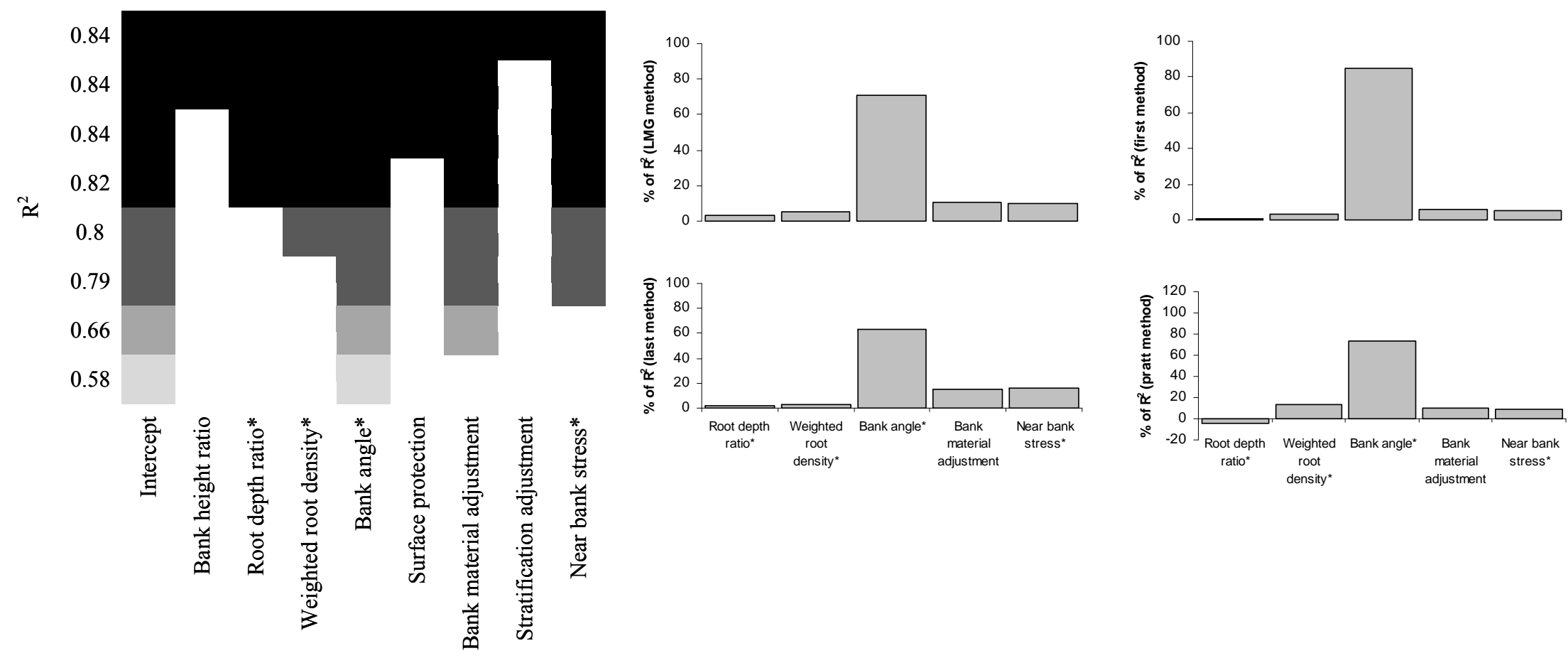
Figure 3.8: All-possible-subset regression was used to identify the subset of BANCS model parameters that could best predict erosion. The best model determined for each subset size in the all subset regression analysis for the lower reach is represented on the left. Bank angle had the highest

correlation with erosion when each parameter was correlated with erosion separately, explaining $28 \%$ of the variation in erosion $\left(R^{2}\right)$. The best model for each pair of parameters included bank angle and surface protection, explaining $56 \%$ of the variation in erosion. The model including bank angle, the vegetation parameters, and bank height ration was selected as the most parsimonious. Relative importance metric plots were plotted for this model. Relative importance measures were calculated using the following methods: average sequential sums of squares over all orderings of regressors,

Lindeman, Merenda, and Gold method (lmg) (Lindeman et al. 1980); comparison of what each regressor was able to explain in addition to all other variables (last); comparison of each regressor alone (first); and comparison of the importance to a variable in proportion to the product of its standardized regression coefficient (Pratt 1987). With the exception of the last method, these metrics indicate that bank angle was the most important variable followed by weighted root density. * indicates the parameter was log base 10 transformed.
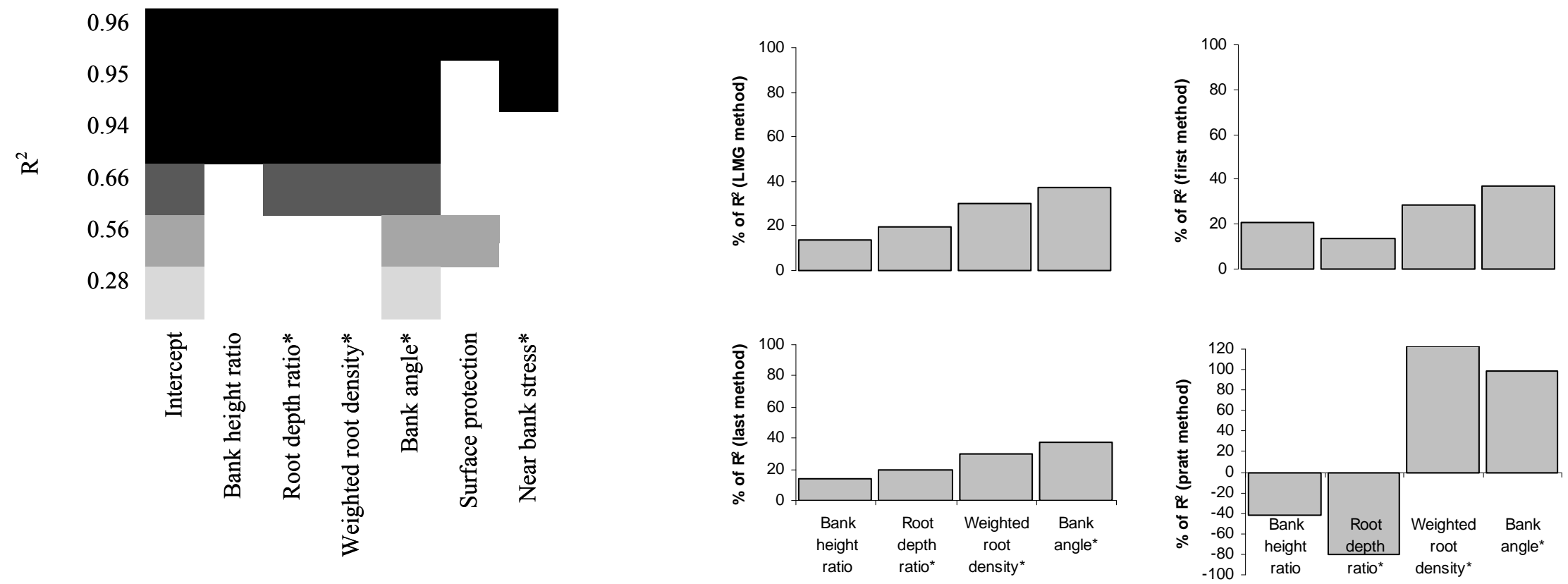
Table 3.4: Regression models for the upper and lower reaches. Parsimonious models, described by the lowest number of parameters with a multiple $\mathbf{r}^{2}$ value $>0.8$ was selected from the subset of all models for each reach.

\begin{tabular}{|c|c|c|c|c|}
\hline Reach & Equation $^{1}$ & $\mathbf{n}$ & $p$-Value & Adjusted $r^{2}$ \\
\hline Upper & $\log E=-4.99-0.67 V_{2}+0.59 V_{3}+1.89 V_{4}+0.167 V_{6}+2.29 V_{8}$ & 15 & 0.001 & 0.7141 \\
\hline Lower & $\log E=26.64-4.32 V_{1}+7.22 V_{2}-6.06 V_{3}-9.07 V_{4}$ & 9 & 0.011 & 0.8754 \\
\hline
\end{tabular}

${ }^{1} \mathrm{E}=$ total erosion $\left(\mathrm{m}^{2}\right), \mathrm{V}_{1}=$ bank height ratio, $\mathrm{V}_{2}=\log \left(\right.$ root depth ratio), $\mathrm{V}_{3}=\log$ (weighted root density), $\mathrm{V}_{4}=\log \left(\right.$ bank angle),$V_{6}=$ bank material adjustment, $\mathrm{V}_{8}=\log (\mathrm{NBS})$ 


\section{Conclusion}

\subsection{Concluding remarks}

Understanding streambank erosion requires an understanding of streamflow hydraulics, hydrology, geomorphology, soil physics, and plant physiology, among other processes. To generate a model that can predict streambank erosion, these disciplines must be integrated. Typically streambank erosion models are divided into two categories: mechanistic models based on established physical principles and empirical models based on local or regional observations. We explored the application of the mechanistic BSTEM and the empirical BANCS model to predict streambank erosion on Horseshoe Run, West Virginia. Both models are potentially valuable tools to assess erosion potential and to prioritize stream reaches for restoration and stabilization.

The debate as to the merits of mechanistic and empirical approaches for predicting fluvial forms is not new (Blench 1962; Leopold and Maddock 1953; Shu-you and Knight 2002). However, the debate has recently been brought to the forefront in many water resource discussions because of the rapidly increasing stream restoration industry. Those supporting mechanistic methods argue that empirical methods do not provide cause and effect relationships (Simon et al. 2007). Those supporting empirical methods argue that mechanistic methods may be impractical because the relevant physical processes are difficult to observe and highly stochastic (Pizzuto 2009).

Both the BSTEM and BANCS model incorporate streambank geometry, bank material, vegetation, and the influence of hydraulic flow (Table 4.1). The BANCS model captures these in general terms while BSTEM incorporates specific functional measures of the more general terms. For instance, the BANCS model characterizes the streambank in terms of bank material 
(cobble, gravel, sand, silt or clay) while BSTEM uses cohesion values of the soil type in the Mohr-Coloumb submodel. The general classification of bank material into soil type is broad while the cohesion value of the soil type is difficult to accurately measure and measurements may not be representative of conditions during erosion (Clark and Wynn 2007). Both models have strengths and weaknesses which are explored in the chapters of this manuscript.

Table 4.1: BSTEM and BANCS model parameters by category.

\begin{tabular}{lll} 
Model Input Parameter Category & BSTEM parameters & BANCS parameters \\
\hline \multirow{3}{*}{ Bank Geometry } & $\begin{array}{l}\text { Bank profile } \\
\text { Shear emergence elevation } \\
\text { Shear surface angle used } \\
\text { Top of toe }\end{array}$ & $\begin{array}{l}\text { Bankfull height } \\
\text { Bank height } \\
\text { Bank angle }\end{array}$ \\
\hline & $\begin{array}{l}\text { Bank layer thicknesses } \\
\text { Friction angle } \\
\text { Cohesion } \\
\text { Sank Material }\end{array}$ & $\begin{array}{l}\text { Bank material adjustment } \\
\text { Stratification adjustment }\end{array}$ \\
& $\begin{array}{l}\text { Critical shear stress } \\
\text { Erodibility coefficient }\end{array}$ & \\
\hline Vegetation & Added cohesion due to roots & Root depth \\
& Root density \\
\hline Protection & Shear stress of bank and/or toe & Surface protection \\
\hline Grotection & Stratification adjustment \\
\hline Flowndwater & Water table depth & Near bank max depth \\
\hline
\end{tabular}

Chapter 2 explores the sensitivity, calibration, and validation of the Bank Stability and Toe Erosion Model (BSTEM). We found that BSTEM could be used cautiously as a relative indicator of erosion without collecting extensive field data. Our first objective explored the sensitivity of the model and revealed that the model was sensitive to the depth and duration of streamflow as well as the critical shear stress of the boundary material. Our results also 
suggested that the model was sensitive to critical shear stress in mixed gravel and cobble bed streams and that critical shear stress values for gravel and cobble should be calibrated based on the size of the non-cohesive particles on the streambed and banks rather than using the cited values.

With regard to our second objective, we determined that the model could be calibrated without collecting extensive field data. The predictive ability of the model was improved by using weighted averages of those values included in the model for friction angle, cohesion, saturated unit weight, critical shear stress and erodibility for the different soil texture classes. Using cohesion values predicted by RipRoot also improved the model performance.

Our third objective of testing the calibrated parameters at additional sites revealed that caution needs to be used in transferring the model parameters to additional sites. The results suggested that critical shear stress of the bed material was locally specific and values could not be assumed for neighboring sites on the same stream. Though BSTEM underpredicted erosion by between 60 and $75 \%$, the model was able to provide relative estimates of eroded material and was also able to predict the type of erosion present at each bank sites. Relative amounts of erosion are often used to help prioritize stream restoration projects; thus this model could aid in the estimation of relative sediment contributions.

Chapter 3 demonstrates that the input parameters for the BANCS model may be used to explain the susceptibility of a streambank to erosion. However, careful consideration needs to be given when using streambank and near bank characteristics to predict erosion on sections of the same stream with different morphology and potentially different dominant erosional processes. With regard to our initial question, we found that the recent restoration activities in the lower reach altered the stream morphology and streambank characteristics from those in the upper 
reach. Because of this difference, streambanks in the two reaches were analyzed separately in the exploration of subsequent objectives.

To meet our next objective, we used cluster analysis to establish groups of streambanks and then compared the observed erosion between these groups. When the streambank parameters were used to group sites independently of erosion, a group of streambanks with moderate rooting depths and densities and low bank angles emerged. This group experienced the least amount of erosion. A variety of vegetation types with a wide distribution of root sizes and depths may provide more stability than larger vegetation with deeper, denser root networks. This might be particular true for incised streams with high hydraulic erosion at the bank toe where the surcharge of large trees may outweigh the stabilizing effects of vegetation.

Lastly, the regression analyses revealed that the different reach morphologies and streambank characteristics between the upper and lower reach did have implications for streambank erosion processes and prediction models. The inverse correlations with erosion and bank angles between the upper and lower reach was a good example of the need to separate reaches along the same river. Higher bank angles in the upper reach were more susceptible to gravitational failure while lower bank angles in the lower reach were more susceptible to fluvial erosion. Additionally, not all parameters should necessarily be weighted equally at all sites. In the BANCS model, measured or estimated BEHI variables are converted to index values based on a series of graphs and the index values are added together for a total index score. The graphs provide some indication as to the influence of the measured value to the overall erosion but our study found that more work may be needed to determine the importance of the variables across multiple reaches. 
The BANCS model provides a solid framework for a comparable, transferable erosion prediction model that could be easily and rapidly applied at a watershed scale. However, we suggest the following improvements to the model: regional relationships for converting the measured ratios to index values should be refined as the regional erosion curves are developed, sets of weighting coefficients based on dominant erosion processes should be explored, and the potentially negative effects of vegetation should be incorporated into the model if present at a site.

\subsection{Related and future work}

BSTEM has been used to compare the stabilizing effects of restoration alternatives (Simon et al. 2009); to quantify the interrelationship of pore-water pressure, vegetation, and seepage undercutting on bank stability (Cancienne et al. 2008); and to quantify rootreinforcement on bank failure (Pollen-Bankhead et al. 2009b). Only one study attempted to validate the model predictions and found that the model overestimated erosion on one reach by 299\% and underestimated erosion at another reach by 55\% (Pollen-Bankhead et al. 2009b). At our study area, BSTEM underpredicted erosion at three sites by $60 \%, 68 \%$, and $75 \%$ and overpredicted erosion at one site by $10 \%$ for an average prediction error of 53\%. BSTEM was, however, able to provide relative estimates of eroded material and was able to predict the type of erosion present at each bank site.

The application of the BANCS model has not been widely published in scientific journals but is applied by watershed and river managers at the state and federal government level (Doll et al. 2003; Van Eps et al. 2004) and was recently adopted by the EPA for use in assessing suspended and bedded sediment loads (Rosgen 2006). However, attempts to generate regional erosion curves have had varying degrees of success (Harmel et al. 1999; Van Eps et al. 2004). 
Our results suggest that the input parameters for the BANCS model may be used to explain the susceptibility of a streambank to erosion. However, model performance could be improved by accounting for the dominant erosional processes responsible for bank loss at a site or reach.

The current debate between empirical and mechanistic modeling in the fluvial community is polarizing (Lave 2009; Rosgen 2008; Simon et al. 2007). We suggest a way forward in which the two methods can be used to inform each other and to advance our understanding of streambank erosion. Our suggestions are outlined in a framework published by Strayer (2003) which reports three ways in which empirical models may relate to more mechanistic models to describe the effects of land-cover change on streams and rivers:

1. empirical models may replace more mechanistic models if there is inadequate information or resources to build reliable mechanistic models

2. empirical models may be used to constrain mechanistic models when both are applied to the same conditions

3. empirical models may be combined with mechanistic models as part of a comprehensive program to understand ecological effects

We discuss these three options in terms of the effects of streambank characteristics to streambank erosion in the mechanistic BSTEM and empirical BANCS model.

\section{Empirical models replacing mechanistic models}

The results of this study suggest that in order for BSTEM to provide reliable results, the hydraulic erosion component of the model needs to be improved. A mechanistic model incorporating a more advanced hydraulic erosion submodel which accounts for secondary flow patterns, was shown to increase model performance at a streambank site in Italy (Rinaldi et al. 
2008). More studies are needed to improve mechanistic models and validate these models on a wide range of stream types and conditions. In the mean time, continued efforts to collect field data, monitor streambank erosion, and expand on the empirical models such as the BANCS model that are currently being applied should be encouraged and maintained.

\section{Empirical models constraining mechanistic models}

Strayer (2003) suggests empirical models can be used to constrain mechanistic models when both are applied to the same conditions. In the case of streambank erosion models, empirical models could be used to constrain mechanistic models and mechanistic models could be used, in turn, to constrain empirical models. For example, subaerial processes are not implicitly included in either the BSTEM or the BANCS model; however, a few studies have incorporated subaerial processes into determining susceptibility to erosion (Prosser et al. 2000; Wynn et al. 2008). Integrating parameters from these findings, such as the number of freeze thaw cycles or the aspect of the bank face, into the BANCS model would be easier than integrating them into a mechanistic model and could be started immediately while integration into BSTEM was explored. Alternatively, mechanistic models could be used to determine the dominant type of erosion and then construct empirical models based on the type of failures present at a site.

\section{Empirical models combining with mechanistic models}

The above relationships between empirical and mechanistic models involve a combined or collaborative approach. This combined approach can be expanded to help guide future efforts. Empirical models could be used at the regional scale to identify streambank sites that are 
contributing large amounts of sediment and prioritize sites accordingly. Refining the models depending on the type of erosion could improve the models. The mechanistic model may be more appropriate at the local scale to explore restoration alternatives; however, further research needs to be done to determine the accuracy and reliability of the mechanistic model. Our results indicate improvements to the toe erosion component of the model may be needed to improve the reliability of the model in mobile gravel and cobble bed streams. Both models may assist in advancing our understanding of streambank erosion and our prioritization and restoration efforts. We recommend continuing to improve both models and continuing to incorporate research findings into the models as they become available. 


\section{Literature Cited}

Blench, T. "Quantitative interrelation of erosion and river regime theory models." Symposium of Bari, Commission on land erosion, Gentbrugge, Belgium, 273-282.

Cancienne, R. M., Fox, G. A., and Simon, A. (2008). "Influence of seepage undercutting on the stability of root-reinforced streambanks." Earth Surface Processes and Landforms, 33, 1769-1786.

Clark, L. A., and Wynn, T. M. (2007). "Methods for determining streambank critical shear stress and soil erodibility: Implications for erosion rate predictions." Transactions of the ASABE, 50(1), 95-106.

Doll, B. A., Grabow, G. L., Hall, K. R., Halley, J., Harman, W. A., Jennings, G. D., and Wise, D. E. (2003). Stream Restoration: A Natural Channel Design Handbook.

Harmel, R. D., Haan, C. T., and Dtnell, R. C. (1999). "Evaluation of Rosgen's streambank erosion potential assessment in Northeast Oklahoma." Journal of the American Water Resources Association, 35(1), 113-121.

Lave, R. (2009). "The controversy over natural channel design: Substantive explanations and potential avenues for resolution." Journal of the American Water Resources Association, 45(6), 1519-1532. 
Leopold, L. B., and Maddock, T. (1953). "The hydraulic geometry of stream channels and some physiographic implications." United States Geologic Survey Professional Paper.

Pizzuto, J. (2009). "An empirical model of event scale cohesive bank profile evolution." Earth Surface Processes and Landforms, 34, 1234-1244.

Pollen-Bankhead, N., Simon, A., Jaeger, K., and Wohl, E. (2009). "Destabilization of streambanks by removal of invasive species in Canyon de Chelly National Monument, Arizona." Geomorphology, 103, 363-374.

Prosser, I. P., Hughes, A. O., and Rutherford, I. D. (2000). "Bank erosion of an incised upland channel by subaerial processes: Tasmania, Australia." Earth Surface Processes and Landforms, 25, 1058-1101.

Rinaldi, M., Mengoni, B., Luppi, L., Darby, S. E., and Mosselman, E. (2008). "Numerical simulation of hydrodynamics and bank erosion in a river bend." Water Resources Research, 44(W09428), doi:10.1029/2008WR007008.

Rosgen, D. (2006). Watershed Assessment of River Stability and Sediment Supply (WARSSS), Wildland Hydrology, Fort Collins, CO.

Rosgen, D. (2008). "Discussion: "Critical evaluation of how the Rosgen classification and associated 'Natural Channel Design' methods fail to integrate and quantify fluvial processes and channel responses" by A. Simon, M. Doyle, M. Kondolf, F.D. Shields Jr., 
B. Rhoads, and M. McPhilips." Journal of the American Water Resources Association, 44(3), 782-792.

Shu-you, C., and Knight, D. W. (2002). "Review of regime theory of alluvial channels." Journal of Hydrodynamics, Series B(3), 1-7.

Simon, A., Doyle, M., Kondolf, M., Shields, F. D., Jr, Rhoads, B., and McPhilips, M. (2007). "Critical evaluation of how the Rosgen classification and associated "Natural Channel Design" methods fail to integrate and quantify fluvial processes and channel response." Journal of the American Water Resources Association, 43(5), 1117-1131.

Simon, A., Pollen-Bankhead, N., Mahacek, V., and Langendoen, E. (2009). "Quantifying reductions of mass-failure frequency and sediment loadings from streambanks using toe protection and other means: Lake Tahoe, United States." Journal of the American Water Resources Association, 45(1), 170-186.

Strayer, D. L., Beighley, R. E., Thompson, L. C., Brooks, S., Nilsson, C., Pinay, G., and Naiman, R. (2003). "Effects of land cover on stream ecosystems: Roles of empirical models and scaling issues." Ecosystems, 6, 407-423.

Van Eps, M. A., Formica, S. J., Morris, T. L., Beck, J. M., and Cotter, A. S. (2004). "Using a bank erosion hazard index (BEHI) to estimate annual sediment loads from streambank erosion in the West Fork White River Watershed." Arkansas Department of 
Environmental Quality, Environmental Preservation Division, 8001 National Drive, Little Rock, AR 72219.

Wynn, T. M., Henderson, M. B., and Vaughan, D. H. (2008). "Changes in streambank erodibility and critical shear stress due to subaerial processes along a headwater stream, southwestern Virginia, USA." Geomorphology, 97, 260-273. 
Appendices

Appendix A: Summary of observed erosion

\begin{tabular}{llll} 
Bank & Reach & Station $(\mathrm{m})$ & Observed Erosion $\left(\mathrm{m}^{2}\right)$ \\
\hline 1 & Upper & 4 & 5.33 \\
2 & Upper & 13 & 4.07 \\
3 & Upper & 90 & 0.62 \\
4 & Upper & 199 & 0.14 \\
5 & Upper & 354 & 0.31 \\
6 & Upper & 374 & 0.17 \\
7 & Upper & 394 & 0.09 \\
8 & Upper & 462 & 1.58 \\
9 & Upper & 621 & 0.54 \\
10 & Upper & 649 & 0.21 \\
11 & Upper & 710 & 1.11 \\
12 & Upper & 734 & 0.24 \\
13 & Upper & 778 & 0.41 \\
14 & Upper & 961 & 0.18 \\
15 & Upper & 1007 & 0.71 \\
16 & Lower & 1063 & 2.94 \\
17 & Lower & 1095 & 0.55 \\
18 & Lower & 1169 & 1.78 \\
19 & Lower & 1170 & 0.28 \\
20 & Lower & 1205 & 1.62 \\
21 & Lower & 1296 & 0.50 \\
22 & Lower & 1400 & 0.64 \\
23 & Lower & 1455 & 0.63 \\
24 & Lower & 1480 & 0.02
\end{tabular}


Appendix B: Individual bank site profile data

\begin{tabular}{|c|c|c|c|}
\hline Bank Site & Date & Station $(m)$ & Elevation (m) \\
\hline$\overline{1}$ & Nov-09 & 4.02 & 486.75 \\
\hline 1 & Nov-09 & 2.45 & 486.79 \\
\hline 1 & Nov-09 & 1.24 & 486.70 \\
\hline 1 & Nov-09 & 0.94 & 486.67 \\
\hline 1 & Nov-09 & 0.69 & 486.60 \\
\hline 1 & Nov-09 & 0.52 & 486.54 \\
\hline 1 & Nov-09 & 0.54 & 486.50 \\
\hline 1 & Nov-09 & 0.58 & 486.45 \\
\hline 1 & Nov-09 & 0.64 & 486.42 \\
\hline 1 & Nov-09 & 0.68 & 486.37 \\
\hline 1 & Nov-09 & 0.68 & 486.35 \\
\hline 1 & Nov-09 & 0.73 & 486.29 \\
\hline 1 & Nov-09 & 0.75 & 486.25 \\
\hline 1 & Nov-09 & 0.84 & 486.19 \\
\hline 1 & Nov-09 & 0.87 & 486.13 \\
\hline 1 & Nov-09 & 1.18 & 486.10 \\
\hline 1 & Nov-09 & 1.31 & 485.99 \\
\hline 1 & Nov-09 & 1.33 & 485.93 \\
\hline 1 & Nov-09 & 1.18 & 485.88 \\
\hline 1 & Nov-09 & 1.09 & 485.81 \\
\hline 1 & Nov-09 & 0.97 & 485.76 \\
\hline 1 & Nov-09 & 0.92 & 485.69 \\
\hline 1 & Nov-09 & 0.91 & 485.63 \\
\hline 1 & Nov-09 & 0.94 & 485.42 \\
\hline 1 & Nov-09 & 0.94 & 485.33 \\
\hline 1 & Nov-09 & 0.96 & 485.16 \\
\hline 1 & Nov-09 & 0.84 & 485.06 \\
\hline 1 & Nov-09 & 0.76 & 484.97 \\
\hline 1 & Nov-09 & 0.38 & 484.85 \\
\hline 1 & Oct-10 & 8.91 & 486.37 \\
\hline 1 & Oct-10 & 6.92 & 486.54 \\
\hline 1 & Oct-10 & 5.16 & 486.76 \\
\hline 1 & Oct-10 & 4.57 & 486.78 \\
\hline 1 & Oct-10 & 4.45 & 486.75 \\
\hline 1 & Oct-10 & 4.42 & 486.73 \\
\hline 1 & Oct-10 & 4.49 & 486.68 \\
\hline 1 & Oct-10 & 4.45 & 486.61 \\
\hline 1 & Oct-10 & 4.44 & 486.53 \\
\hline 1 & Oct-10 & 4.51 & 486.46 \\
\hline 1 & Oct-10 & 4.52 & 486.38 \\
\hline 1 & Oct-10 & 4.19 & 486.37 \\
\hline 1 & Oct-10 & 4.13 & 486.22 \\
\hline 1 & Oct-10 & 4.10 & 486.06 \\
\hline 1 & Oct-10 & 4.09 & 485.97 \\
\hline 1 & Oct-10 & 4.03 & 485.89 \\
\hline 1 & Oct-10 & 4.17 & 485.86 \\
\hline 1 & Oct-10 & 4.15 & 485.80 \\
\hline 1 & Oct-10 & 4.15 & 485.72 \\
\hline 1 & Oct-10 & 4.25 & 485.55 \\
\hline 1 & Oct-10 & 4.39 & 485.47 \\
\hline 1 & Oct-10 & 4.39 & 485.45 \\
\hline 1 & Oct-10 & 4.21 & 485.35 \\
\hline 1 & Oct-10 & 4.01 & 485.27 \\
\hline 1 & Oct-10 & 3.77 & 485.16 \\
\hline 1 & Oct-10 & 3.63 & 485.09 \\
\hline 1 & Oct-10 & 3.08 & 484.99 \\
\hline 1 & Oct-10 & 3.01 & 484.89 \\
\hline 1 & Oct-10 & 2.86 & 484.80 \\
\hline 1 & Oct-10 & 1.15 & 484.55 \\
\hline 1 & Oct-10 & -0.32 & 484.43 \\
\hline
\end{tabular}




\begin{tabular}{|c|c|c|c|}
\hline Bank Site & Date & Station $(\mathrm{m})$ & Elevation (m) \\
\hline 2 & Nov-09 & 2.85 & 486.53 \\
\hline 2 & Nov-09 & 2.28 & 486.57 \\
\hline 2 & Nov-09 & 1.65 & 486.60 \\
\hline 2 & Nov-09 & 1.44 & 486.43 \\
\hline 2 & Nov-09 & 1.19 & 486.38 \\
\hline 2 & Nov-09 & 1.07 & 486.24 \\
\hline 2 & Nov-09 & 1.03 & 486.15 \\
\hline 2 & Nov-09 & 0.99 & 486.01 \\
\hline 2 & Nov-09 & 0.98 & 485.90 \\
\hline 2 & Nov-09 & 1.03 & 485.84 \\
\hline 2 & Nov-09 & 0.89 & 485.76 \\
\hline 2 & Nov-09 & 0.88 & 485.60 \\
\hline 2 & Nov-09 & 0.90 & 485.59 \\
\hline 2 & Nov-09 & 0.94 & 485.40 \\
\hline 2 & Nov-09 & 0.91 & 485.31 \\
\hline 2 & Nov-09 & 0.98 & 485.19 \\
\hline 2 & Nov-09 & 0.99 & 485.13 \\
\hline 2 & Nov-09 & 0.94 & 485.06 \\
\hline 2 & Nov-09 & 0.64 & 484.95 \\
\hline 2 & Nov-09 & 0.24 & 484.84 \\
\hline 2 & Oct-10 & 9.27 & 486.51 \\
\hline 2 & Oct-10 & 6.31 & 486.57 \\
\hline 2 & Oct-10 & 4.41 & 486.49 \\
\hline 2 & Oct-10 & 3.51 & 486.48 \\
\hline 2 & Oct-10 & 3.29 & 486.44 \\
\hline 2 & Oct-10 & 3.27 & 486.39 \\
\hline 2 & Oct-10 & 3.35 & 486.32 \\
\hline 2 & Oct-10 & 3.44 & 486.27 \\
\hline 2 & Oct-10 & 3.46 & 486.22 \\
\hline 2 & Oct-10 & 3.44 & 486.13 \\
\hline 2 & Oct-10 & 3.48 & 486.06 \\
\hline 2 & Oct-10 & 3.51 & 485.97 \\
\hline 2 & Oct-10 & 3.52 & 485.85 \\
\hline 2 & Oct-10 & 3.46 & 485.69 \\
\hline 2 & Oct-10 & 3.55 & 485.65 \\
\hline 2 & Oct-10 & 3.63 & 485.57 \\
\hline 2 & Oct-10 & 3.72 & 485.40 \\
\hline 2 & Oct-10 & 3.72 & 485.22 \\
\hline 2 & Oct-10 & 3.68 & 485.05 \\
\hline 2 & Oct-10 & 3.53 & 484.99 \\
\hline 2 & Oct-10 & 3.43 & 484.92 \\
\hline 2 & Oct-10 & 3.08 & 484.83 \\
\hline 2 & Oct-10 & 2.62 & 484.75 \\
\hline 2 & Oct-10 & 2.59 & 484.68 \\
\hline 2 & Oct-10 & 0.70 & 484.42 \\
\hline 2 & Oct-10 & 0.06 & 484.30 \\
\hline 2 & Oct-10 & -1.14 & 484.37 \\
\hline
\end{tabular}




\begin{tabular}{|c|c|c|c|}
\hline Bank Site & Date & Station $(\mathrm{m})$ & Elevation (m) \\
\hline$\overline{3}$ & Nov-09 & 2.73 & 485.72 \\
\hline 3 & Nov-09 & 1.82 & 485.82 \\
\hline 3 & Nov-09 & 1.23 & 485.82 \\
\hline 3 & Nov-09 & 0.80 & 485.78 \\
\hline 3 & Nov-09 & 0.80 & 485.76 \\
\hline 3 & Nov-09 & 0.81 & 485.71 \\
\hline 3 & Nov-09 & 0.84 & 485.67 \\
\hline 3 & Nov-09 & 0.80 & 485.52 \\
\hline 3 & Nov-09 & 0.78 & 485.38 \\
\hline 3 & Nov-09 & 0.78 & 485.34 \\
\hline 3 & Nov-09 & 0.82 & 485.27 \\
\hline 3 & Nov-09 & 0.83 & 485.24 \\
\hline 3 & Nov-09 & 0.85 & 485.22 \\
\hline 3 & Nov-09 & 0.86 & 485.17 \\
\hline 3 & Nov-09 & 0.87 & 485.14 \\
\hline 3 & Nov-09 & 0.85 & 485.06 \\
\hline 3 & Nov-09 & 0.85 & 484.99 \\
\hline 3 & Nov-09 & 0.48 & 484.91 \\
\hline 3 & Nov-09 & 0.83 & 484.85 \\
\hline 3 & Nov-09 & 0.78 & 484.77 \\
\hline 3 & Nov-09 & 0.69 & 484.69 \\
\hline 3 & Nov-09 & 0.61 & 484.61 \\
\hline 3 & Nov-09 & 0.51 & 484.54 \\
\hline 3 & Nov-09 & 0.48 & 484.47 \\
\hline 3 & Nov-09 & 0.51 & 484.42 \\
\hline 3 & Nov-09 & 0.57 & 484.34 \\
\hline 3 & Nov-09 & 0.00 & 484.17 \\
\hline 3 & Oct-10 & 2.73 & 485.71 \\
\hline 3 & Oct-10 & 1.81 & 485.82 \\
\hline 3 & Oct-10 & 1.56 & 485.78 \\
\hline 3 & Oct-10 & 1.19 & 485.77 \\
\hline 3 & Oct-10 & 1.31 & 485.58 \\
\hline 3 & Oct-10 & 1.45 & 485.54 \\
\hline 3 & Oct-10 & 1.46 & 485.43 \\
\hline 3 & Oct-10 & 1.45 & 485.34 \\
\hline 3 & Oct-10 & 1.42 & 485.22 \\
\hline 3 & Oct-10 & 1.36 & 485.13 \\
\hline 3 & Oct-10 & 1.26 & 484.99 \\
\hline 3 & Oct-10 & 1.24 & 484.91 \\
\hline 3 & Oct-10 & 1.20 & 484.87 \\
\hline 3 & Oct-10 & 1.13 & 484.80 \\
\hline 3 & Oct-10 & 1.06 & 484.73 \\
\hline 3 & Oct-10 & 0.74 & 484.60 \\
\hline 3 & Oct-10 & 0.66 & 484.38 \\
\hline 3 & Oct-10 & -0.70 & 484.24 \\
\hline 3 & Oct-10 & -3.73 & 484.09 \\
\hline
\end{tabular}




\begin{tabular}{|c|c|c|c|}
\hline Bank Site & Date & Station $(\mathrm{m})$ & Elevation (m) \\
\hline$\overline{4}$ & Nov-09 & 0.00 & 484.97 \\
\hline 4 & Nov-09 & 1.41 & 485.04 \\
\hline 4 & Nov-09 & 2.07 & 484.96 \\
\hline 4 & Nov-09 & 2.37 & 484.96 \\
\hline 4 & Nov-09 & 2.78 & 484.88 \\
\hline 4 & Nov-09 & 2.86 & 484.79 \\
\hline 4 & Nov-09 & 2.87 & 484.76 \\
\hline 4 & Nov-09 & 2.56 & 484.72 \\
\hline 4 & Nov-09 & 2.59 & 484.67 \\
\hline 4 & Nov-09 & 2.59 & 484.65 \\
\hline 4 & Nov-09 & 2.49 & 484.52 \\
\hline 4 & Nov-09 & 2.69 & 484.46 \\
\hline 4 & Nov-09 & 2.73 & 484.39 \\
\hline 4 & Nov-09 & 2.84 & 484.28 \\
\hline 4 & Nov-09 & 2.98 & 484.14 \\
\hline 4 & Nov-09 & 3.13 & 484.04 \\
\hline 4 & Nov-09 & 3.19 & 483.99 \\
\hline 4 & Nov-09 & 3.32 & 483.89 \\
\hline 4 & Nov-09 & 3.50 & 483.80 \\
\hline 4 & Nov-09 & 3.72 & 483.97 \\
\hline 4 & Nov-09 & 4.02 & 483.56 \\
\hline 4 & Nov-09 & 4.41 & 483.46 \\
\hline 4 & Oct-10 & 0.00 & 484.95 \\
\hline 4 & Oct-10 & 1.42 & 485.04 \\
\hline 4 & Oct-10 & 1.93 & 484.96 \\
\hline 4 & Oct-10 & 2.45 & 484.95 \\
\hline 4 & Oct-10 & 2.64 & 484.88 \\
\hline 4 & Oct-10 & 2.66 & 484.74 \\
\hline 4 & Oct-10 & 2.72 & 484.67 \\
\hline 4 & Oct-10 & 2.36 & 484.60 \\
\hline 4 & Oct-10 & 2.38 & 484.57 \\
\hline 4 & Oct-10 & 2.32 & 484.49 \\
\hline 4 & Oct-10 & 2.50 & 484.37 \\
\hline 4 & Oct-10 & 2.71 & 484.25 \\
\hline 4 & Oct-10 & 2.85 & 484.18 \\
\hline 4 & Oct-10 & 3.00 & 484.18 \\
\hline 4 & Oct-10 & 3.10 & 484.08 \\
\hline 4 & Oct-10 & 3.33 & 483.99 \\
\hline 4 & Oct-10 & 3.67 & 483.86 \\
\hline 4 & Oct-10 & 3.83 & 483.76 \\
\hline 4 & Oct-10 & 4.04 & 483.70 \\
\hline 4 & Oct-10 & 5.95 & 483.33 \\
\hline 4 & Oct-10 & 7.74 & 483.15 \\
\hline
\end{tabular}




\begin{tabular}{llll} 
Bank Site & Date & Station $(\mathbf{m})$ & Elevation $(\mathbf{m})$ \\
\hline 5 & Nov-09 & 0.00 & 485.11 \\
5 & Nov-09 & 0.25 & 485.05 \\
5 & Nov-09 & 0.50 & 484.99 \\
5 & Nov-09 & 0.55 & 484.88 \\
5 & Nov-09 & 0.49 & 484.85 \\
5 & Nov-09 & 0.38 & 484.81 \\
5 & Nov-09 & 0.38 & 484.74 \\
5 & Nov-09 & 0.49 & 484.65 \\
5 & Nov-09 & 0.63 & 484.53 \\
5 & Nov-09 & 0.70 & 484.41 \\
5 & Nov-09 & 0.70 & 484.35 \\
5 & Nov-09 & 0.77 & 484.30 \\
5 & Nov-09 & 0.80 & 484.14 \\
5 & Nov-09 & 0.91 & 484.04 \\
5 & Nov-09 & 1.09 & 483.87 \\
5 & Nov-09 & 1.22 & 483.77 \\
5 & Nov-09 & 1.34 & 483.61 \\
5 & Nov-09 & 1.41 & 483.49 \\
5 & Nov-09 & 1.48 & 483.43 \\
5 & Nov-09 & 1.73 & 483.32 \\
5 & Nov-09 & 1.98 & 483.19 \\
5 & Oct-10 & 0.35 & 485.00 \\
5 & Oct-10 & 0.27 & 484.94 \\
5 & Oct-10 & 0.29 & 484.88 \\
5 & Oct-10 & 0.19 & 484.82 \\
5 & Oct-10 & 0.23 & 484.78 \\
5 & Oct-10 & 1.20 & 484.72 \\
5 & Oct-10 & 0.34 & 484.64 \\
5 & Oct-10 & 0.44 & 484.53 \\
5 & Oct-10 & 0.55 & 484.38 \\
5 & Oct-10 & 0.59 & 484.30 \\
5 & Oct-10 & 0.79 & 484.28 \\
5 & Oct-10 & 0.70 & 484.11 \\
5 & Oct-10 & 0.93 & 483.89 \\
5 & Oct-10 & 0.97 & 483.82 \\
5 & Oct-10 & 1.05 & 483.75 \\
5 & Oct-10 & 1.17 & 483.61 \\
5 & Oct-10 & 1.32 & 483.48 \\
5 & Oct-10 & 1.42 & 483.34 \\
5 & Oct-10 & 1.62 & 483.19 \\
5 & Oct-10 & 2.02 & 482.99 \\
5 & Oct-10 & 2.23 & 482.87 \\
& Oct-10 & 4.87 & 482.61 \\
5 & Oct-10 & 7.21 & 482.69
\end{tabular}




\begin{tabular}{|c|c|c|c|}
\hline Bank Site & Date & Station $(m)$ & Elevation (m) \\
\hline$\overline{6}$ & Nov-09 & 0.00 & 484.17 \\
\hline 6 & Nov-09 & 0.79 & 484.17 \\
\hline 6 & Nov-09 & 1.56 & 484.13 \\
\hline 6 & Nov-09 & 1.98 & 484.13 \\
\hline 6 & Nov-09 & 2.33 & 484.12 \\
\hline 6 & Nov-09 & 2.35 & 484.11 \\
\hline 6 & Nov-09 & 2.34 & 484.02 \\
\hline 6 & Nov-09 & 2.34 & 483.96 \\
\hline 6 & Nov-09 & 2.32 & 483.93 \\
\hline 6 & Nov-09 & 2.26 & 483.78 \\
\hline 6 & Nov-09 & 2.25 & 483.75 \\
\hline 6 & Nov-09 & 2.26 & 483.73 \\
\hline 6 & Nov-09 & 2.33 & 483.69 \\
\hline 6 & Nov-09 & 2.42 & 483.62 \\
\hline 6 & Nov-09 & 2.60 & 483.50 \\
\hline 6 & Nov-09 & 2.77 & 483.39 \\
\hline 6 & Nov-09 & 2.79 & 483.35 \\
\hline 6 & Nov-09 & 2.97 & 483.38 \\
\hline 6 & Nov-09 & 3.08 & 483.22 \\
\hline 6 & Nov-09 & 3.07 & 483.17 \\
\hline 6 & Nov-09 & 3.08 & 483.11 \\
\hline 6 & Nov-09 & 3.23 & 483.03 \\
\hline 6 & Nov-09 & 3.41 & 482.96 \\
\hline 6 & Nov-09 & 3.51 & 482.89 \\
\hline 6 & Nov-09 & 3.49 & 482.83 \\
\hline 6 & Nov-09 & 3.64 & 482.74 \\
\hline 6 & Nov-09 & 3.96 & 482.67 \\
\hline 6 & Nov-09 & 4.37 & 482.52 \\
\hline 6 & Oct-10 & 0.00 & 484.19 \\
\hline 6 & Oct-10 & 0.76 & 484.17 \\
\hline 6 & Oct-10 & 1.62 & 484.12 \\
\hline 6 & Oct-10 & 2.40 & 484.03 \\
\hline 6 & Oct-10 & 2.32 & 483.86 \\
\hline 6 & Oct-10 & 2.15 & 483.86 \\
\hline 6 & Oct-10 & 2.09 & 483.78 \\
\hline 6 & Oct-10 & 2.11 & 483.71 \\
\hline 6 & Oct-10 & 2.37 & 483.62 \\
\hline 6 & Oct-10 & 2.49 & 483.55 \\
\hline 6 & Oct-10 & 2.51 & 483.53 \\
\hline 6 & Oct-10 & 2.71 & 483.41 \\
\hline 6 & Oct-10 & 2.74 & 483.37 \\
\hline 6 & Oct-10 & 2.73 & 483.31 \\
\hline 6 & Oct-10 & 2.92 & 483.22 \\
\hline 6 & Oct-10 & 3.03 & 483.11 \\
\hline 6 & Oct-10 & 3.11 & 483.03 \\
\hline 6 & Oct-10 & 3.24 & 482.93 \\
\hline 6 & Oct-10 & 3.40 & 482.84 \\
\hline 6 & Oct-10 & 3.58 & 482.78 \\
\hline 6 & Oct-10 & 3.74 & 482.72 \\
\hline 6 & Oct-10 & 6.29 & 482.52 \\
\hline 6 & Oct-10 & 9.10 & 482.48 \\
\hline
\end{tabular}




\begin{tabular}{|c|c|c|c|}
\hline Bank Site & Date & Station (m) & Elevation (m) \\
\hline 7 & Nov-09 & 0.00 & 484.31 \\
\hline 7 & Nov-09 & 0.48 & 484.36 \\
\hline 7 & Nov-09 & 1.20 & 484.33 \\
\hline 7 & Nov-09 & 1.49 & 484.32 \\
\hline 7 & Nov-09 & 1.76 & 484.26 \\
\hline 7 & Nov-09 & 1.75 & 484.21 \\
\hline 7 & Nov-09 & 1.72 & 484.11 \\
\hline 7 & Nov-09 & 1.65 & 484.00 \\
\hline 7 & Nov-09 & 1.67 & 483.84 \\
\hline 7 & Nov-09 & 1.67 & 483.74 \\
\hline 7 & Nov-09 & 1.64 & 483.66 \\
\hline 7 & Nov-09 & 1.91 & 483.51 \\
\hline 7 & Nov-09 & 2.02 & 483.40 \\
\hline 7 & Nov-09 & 2.14 & 483.32 \\
\hline 7 & Nov-09 & 2.24 & 483.25 \\
\hline 7 & Nov-09 & 2.55 & 483.11 \\
\hline 7 & Nov-09 & 2.75 & 483.01 \\
\hline 7 & Nov-09 & 2.79 & 482.90 \\
\hline 7 & Nov-09 & 2.87 & 482.85 \\
\hline 7 & Nov-09 & 3.00 & 482.74 \\
\hline 7 & Nov-09 & 3.24 & 482.68 \\
\hline 7 & Nov-09 & 3.44 & 482.58 \\
\hline 7 & Oct-10 & 0.00 & 484.32 \\
\hline 7 & Oct-10 & 1.00 & 484.44 \\
\hline 7 & Oct-10 & 1.34 & 484.35 \\
\hline 7 & Oct-10 & 1.63 & 484.31 \\
\hline 7 & Oct-10 & 1.70 & 484.21 \\
\hline 7 & Oct-10 & 1.70 & 484.16 \\
\hline 7 & Oct-10 & 1.58 & 484.12 \\
\hline 7 & Oct-10 & 1.58 & 484.06 \\
\hline 7 & Oct-10 & 1.56 & 484.00 \\
\hline 7 & Oct-10 & 1.56 & 483.91 \\
\hline 7 & Oct-10 & 1.55 & 483.84 \\
\hline 7 & Oct-10 & 1.57 & 483.67 \\
\hline 7 & Oct-10 & 1.69 & 483.62 \\
\hline 7 & Oct-10 & 1.76 & 483.58 \\
\hline 7 & Oct-10 & 1.91 & 483.53 \\
\hline 7 & Oct-10 & 1.86 & 483.45 \\
\hline 7 & Oct-10 & 1.96 & 483.40 \\
\hline 7 & Oct-10 & 2.17 & 483.32 \\
\hline 7 & Oct-10 & 2.35 & 483.24 \\
\hline 7 & Oct-10 & 2.51 & 483.17 \\
\hline 7 & Oct-10 & 2.67 & 483.08 \\
\hline 7 & Oct-10 & 2.66 & 483.01 \\
\hline 7 & Oct-10 & 2.72 & 482.97 \\
\hline 7 & Oct-10 & 2.73 & 482.90 \\
\hline 7 & Oct-10 & 2.96 & 482.81 \\
\hline 7 & Oct-10 & 3.16 & 482.75 \\
\hline 7 & Oct-10 & 5.32 & 482.51 \\
\hline 7 & Oct-10 & 7.50 & 482.58 \\
\hline
\end{tabular}




\begin{tabular}{|c|c|c|c|}
\hline Bank Site & Date & Station (m) & Elevation (m) \\
\hline 8 & Nov-09 & 0.00 & 483.42 \\
\hline 8 & Nov-09 & 0.77 & 483.34 \\
\hline 8 & Nov-09 & 1.24 & 483.30 \\
\hline 8 & Nov-09 & 1.67 & 483.21 \\
\hline 8 & Nov-09 & 1.74 & 483.13 \\
\hline 8 & Nov-09 & 1.66 & 483.10 \\
\hline 8 & Nov-09 & 1.61 & 483.08 \\
\hline 8 & Nov-09 & 1.68 & 483.03 \\
\hline 8 & Nov-09 & 1.66 & 482.97 \\
\hline 8 & Nov-09 & 1.60 & 482.92 \\
\hline 8 & Nov-09 & 1.57 & 482.87 \\
\hline 8 & Nov-09 & 1.51 & 482.79 \\
\hline 8 & Nov-09 & 1.50 & 482.78 \\
\hline 8 & Nov-09 & 1.52 & 482.67 \\
\hline 8 & Nov-09 & 1.24 & 482.64 \\
\hline 8 & Nov-09 & 1.31 & 482.57 \\
\hline 8 & Nov-09 & 1.50 & 482.47 \\
\hline 8 & Nov-09 & 1.69 & 482.40 \\
\hline 8 & Nov-09 & 1.82 & 482.35 \\
\hline 8 & Nov-09 & 1.90 & 482.30 \\
\hline 8 & Nov-09 & 2.00 & 482.27 \\
\hline 8 & Nov-09 & 2.67 & 482.12 \\
\hline 8 & Nov-09 & 5.27 & 482.12 \\
\hline 8 & Oct-10 & -1.07 & 483.40 \\
\hline 8 & Oct-10 & 0.00 & 483.40 \\
\hline 8 & Oct-10 & 0.01 & 483.29 \\
\hline 8 & Oct-10 & 0.35 & 483.26 \\
\hline 8 & Oct-10 & 0.62 & 483.18 \\
\hline 8 & Oct-10 & 0.61 & 483.06 \\
\hline 8 & Oct-10 & 0.59 & 483.04 \\
\hline 8 & Oct-10 & 0.59 & 483.01 \\
\hline 8 & Oct-10 & 0.69 & 482.98 \\
\hline 8 & Oct-10 & 0.65 & 482.90 \\
\hline 8 & Oct-10 & 0.55 & 482.84 \\
\hline 8 & Oct-10 & 0.35 & 482.76 \\
\hline 8 & Oct-10 & 0.35 & 482.67 \\
\hline 8 & Oct-10 & 0.28 & 482.57 \\
\hline 8 & Oct-10 & 0.65 & 482.43 \\
\hline 8 & Oct-10 & 0.60 & 482.28 \\
\hline 8 & Oct-10 & 0.29 & 482.25 \\
\hline 8 & Oct-10 & 0.36 & 482.19 \\
\hline 8 & Oct-10 & 0.40 & 482.09 \\
\hline 8 & Oct-10 & 0.48 & 482.02 \\
\hline 8 & Oct-10 & 0.71 & 481.94 \\
\hline 8 & Oct-10 & 2.80 & 481.75 \\
\hline
\end{tabular}




\begin{tabular}{|c|c|c|c|}
\hline Bank Site & Date & Station $(\mathrm{m})$ & Elevation (m) \\
\hline$\overline{9}$ & Nov-09 & 2.55 & 482.40 \\
\hline 9 & Nov-09 & 1.80 & 482.44 \\
\hline 9 & Nov-09 & 1.26 & 482.39 \\
\hline 9 & Nov-09 & 0.86 & 482.30 \\
\hline 9 & Nov-09 & 0.83 & 482.24 \\
\hline 9 & Nov-09 & 0.84 & 482.21 \\
\hline 9 & Nov-09 & 0.87 & 482.16 \\
\hline 9 & Nov-09 & 0.96 & 482.10 \\
\hline 9 & Nov-09 & 1.06 & 482.08 \\
\hline 9 & Nov-09 & 1.18 & 482.01 \\
\hline 9 & Nov-09 & 1.24 & 481.96 \\
\hline 9 & Nov-09 & 1.27 & 481.91 \\
\hline 9 & Nov-09 & 1.29 & 481.79 \\
\hline 9 & Nov-09 & 1.25 & 481.76 \\
\hline 9 & Nov-09 & 1.20 & 481.67 \\
\hline 9 & Nov-09 & 0.99 & 481.50 \\
\hline 9 & Nov-09 & 0.74 & 481.40 \\
\hline 9 & Nov-09 & 0.56 & 481.28 \\
\hline 9 & Nov-09 & 0.19 & 481.15 \\
\hline 9 & Nov-09 & 0.00 & 481.08 \\
\hline 9 & Oct-10 & 2.55 & 482.39 \\
\hline 9 & Oct-10 & 1.81 & 482.44 \\
\hline 9 & Oct-10 & 1.61 & 482.46 \\
\hline 9 & Oct-10 & 1.37 & 482.40 \\
\hline 9 & Oct-10 & 1.33 & 482.26 \\
\hline 9 & Oct-10 & 1.35 & 482.21 \\
\hline 9 & Oct-10 & 1.37 & 482.19 \\
\hline 9 & Oct-10 & 1.54 & 482.09 \\
\hline 9 & Oct-10 & 1.52 & 481.88 \\
\hline 9 & Oct-10 & 1.54 & 481.83 \\
\hline 9 & Oct-10 & 1.50 & 481.79 \\
\hline 9 & Oct-10 & 1.51 & 481.74 \\
\hline 9 & Oct-10 & 1.47 & 481.71 \\
\hline 9 & Oct-10 & 1.27 & 481.75 \\
\hline 9 & Oct-10 & 1.36 & 481.66 \\
\hline 9 & Oct-10 & 1.36 & 481.58 \\
\hline 9 & Oct-10 & 1.35 & 481.50 \\
\hline 9 & Oct-10 & 1.27 & 481.43 \\
\hline 9 & Oct-10 & 1.20 & 481.36 \\
\hline 9 & Oct-10 & 1.16 & 481.27 \\
\hline 9 & Oct-10 & 0.90 & 481.12 \\
\hline 9 & Oct-10 & 0.54 & 480.96 \\
\hline 9 & Oct-10 & 0.35 & 480.79 \\
\hline 9 & Oct-10 & -0.74 & 480.81 \\
\hline 9 & Oct-10 & -2.08 & 480.58 \\
\hline
\end{tabular}




\begin{tabular}{|c|c|c|c|}
\hline Bank Site & Date & Station $(m)$ & Elevation (m) \\
\hline 10 & Nov-09 & 3.24 & 482.23 \\
\hline 10 & Nov-09 & 2.59 & 482.20 \\
\hline 10 & Nov-09 & 2.35 & 482.06 \\
\hline 10 & Nov-09 & 2.17 & 482.04 \\
\hline 10 & Nov-09 & 2.10 & 482.01 \\
\hline 10 & Nov-09 & 2.07 & 481.91 \\
\hline 10 & Nov-09 & 2.06 & 481.87 \\
\hline 10 & Nov-09 & 2.05 & 481.76 \\
\hline 10 & Nov-09 & 2.03 & 481.69 \\
\hline 10 & Nov-09 & 2.01 & 481.63 \\
\hline 10 & Nov-09 & 1.99 & 481.61 \\
\hline 10 & Nov-09 & 1.88 & 481.51 \\
\hline 10 & Nov-09 & 1.75 & 481.42 \\
\hline 10 & Nov-09 & 1.68 & 481.39 \\
\hline 10 & Nov-09 & 1.37 & 481.27 \\
\hline 10 & Nov-09 & 0.97 & 481.18 \\
\hline 10 & Nov-09 & 0.48 & 481.11 \\
\hline 10 & Oct-10 & 3.24 & 482.23 \\
\hline 10 & Oct-10 & 2.59 & 482.20 \\
\hline 10 & Oct-10 & 2.56 & 482.06 \\
\hline 10 & Oct-10 & 2.42 & 482.01 \\
\hline 10 & Oct-10 & 2.30 & 481.94 \\
\hline 10 & Oct-10 & 2.31 & 481.90 \\
\hline 10 & Oct-10 & 2.29 & 481.86 \\
\hline 10 & Oct-10 & 2.07 & 481.86 \\
\hline 10 & Oct-10 & 2.25 & 481.77 \\
\hline 10 & Oct-10 & 2.19 & 481.71 \\
\hline 10 & Oct-10 & 2.13 & 481.67 \\
\hline 10 & Oct-10 & 2.10 & 481.57 \\
\hline 10 & Oct-10 & 2.02 & 481.45 \\
\hline 10 & Oct-10 & 1.93 & 481.39 \\
\hline 10 & Oct-10 & 1.64 & 481.23 \\
\hline 10 & Oct-10 & 1.25 & 481.14 \\
\hline 10 & Oct-10 & -1.32 & 480.97 \\
\hline 10 & Oct-10 & -4.12 & 480.91 \\
\hline
\end{tabular}




\begin{tabular}{|c|c|c|c|}
\hline Bank Site & Date & Station (m) & Elevation (m) \\
\hline 11 & Nov-09 & 3.58 & 483.13 \\
\hline 11 & Nov-09 & 2.73 & 483.08 \\
\hline 11 & Nov-09 & 2.12 & 483.01 \\
\hline 11 & Nov-09 & 1.75 & 483.06 \\
\hline 11 & Nov-09 & 1.44 & 482.98 \\
\hline 11 & Nov-09 & 1.43 & 482.90 \\
\hline 11 & Nov-09 & 1.44 & 482.84 \\
\hline 11 & Nov-09 & 1.48 & 482.72 \\
\hline 11 & Nov-09 & 1.52 & 482.68 \\
\hline 11 & Nov-09 & 1.52 & 482.60 \\
\hline 11 & Nov-09 & 1.46 & 482.56 \\
\hline 11 & Nov-09 & 1.42 & 482.50 \\
\hline 11 & Nov-09 & 1.44 & 482.41 \\
\hline 11 & Nov-09 & 1.50 & 482.36 \\
\hline 11 & Nov-09 & 1.62 & 482.25 \\
\hline 11 & Nov-09 & 1.59 & 482.12 \\
\hline 11 & Nov-09 & 1.45 & 481.93 \\
\hline 11 & Nov-09 & 1.41 & 481.83 \\
\hline 11 & Nov-09 & 1.48 & 481.78 \\
\hline 11 & Nov-09 & 1.29 & 481.78 \\
\hline 11 & Nov-09 & 1.34 & 481.71 \\
\hline 11 & Nov-09 & 1.37 & 481.67 \\
\hline 11 & Nov-09 & 1.34 & 481.55 \\
\hline 11 & Nov-09 & 1.28 & 481.36 \\
\hline 11 & Nov-09 & 1.14 & 481.27 \\
\hline 11 & Nov-09 & 1.14 & 481.20 \\
\hline 11 & Nov-09 & 1.04 & 481.11 \\
\hline 11 & Nov-09 & 0.78 & 481.05 \\
\hline 11 & Nov-09 & 0.71 & 480.95 \\
\hline 11 & Nov-09 & 0.00 & 480.61 \\
\hline 11 & Oct-10 & 3.58 & 483.12 \\
\hline 11 & Oct-10 & 2.73 & 483.08 \\
\hline 11 & Oct-10 & 2.41 & 482.99 \\
\hline 11 & Oct-10 & 2.11 & 482.88 \\
\hline 11 & Oct-10 & 2.11 & 482.82 \\
\hline 11 & Oct-10 & 2.20 & 482.77 \\
\hline 11 & Oct-10 & 2.32 & 482.73 \\
\hline 11 & Oct-10 & 2.35 & 482.68 \\
\hline 11 & Oct-10 & 2.34 & 482.56 \\
\hline 11 & Oct-10 & 2.33 & 482.44 \\
\hline 11 & Oct-10 & 2.32 & 482.37 \\
\hline 11 & Oct-10 & 2.36 & 482.28 \\
\hline 11 & Oct-10 & 2.43 & 482.26 \\
\hline 11 & Oct-10 & 2.39 & 482.17 \\
\hline 11 & Oct-10 & 2.45 & 482.11 \\
\hline 11 & Oct-10 & 2.08 & 481.87 \\
\hline 11 & Oct-10 & 1.77 & 481.71 \\
\hline 11 & Oct-10 & 1.68 & 481.65 \\
\hline 11 & Oct-10 & 1.46 & 481.57 \\
\hline 11 & Oct-10 & 1.36 & 481.49 \\
\hline 11 & Oct-10 & 1.31 & 481.42 \\
\hline 11 & Oct-10 & 1.22 & 481.33 \\
\hline 11 & Oct-10 & 1.16 & 481.25 \\
\hline 11 & Oct-10 & 1.01 & 481.14 \\
\hline 11 & Oct-10 & 1.01 & 481.09 \\
\hline 11 & Oct-10 & 0.86 & 480.99 \\
\hline 11 & Oct-10 & 0.82 & 480.92 \\
\hline 11 & Oct-10 & 0.59 & 480.85 \\
\hline 11 & Oct-10 & 0.28 & 480.69 \\
\hline 11 & Oct-10 & -0.88 & 480.45 \\
\hline 11 & Oct-10 & -3.61 & 480.57 \\
\hline
\end{tabular}




\begin{tabular}{|c|c|c|c|}
\hline Bank Site & Date & Station (m) & Elevation (m) \\
\hline 12 & Nov-09 & 4.02 & 482.60 \\
\hline 12 & Nov-09 & 2.78 & 482.53 \\
\hline 12 & Nov-09 & 2.29 & 482.51 \\
\hline 12 & Nov-09 & 1.88 & 482.50 \\
\hline 12 & Nov-09 & 1.86 & 482.44 \\
\hline 12 & Nov-09 & 1.85 & 482.38 \\
\hline 12 & Nov-09 & 1.85 & 482.29 \\
\hline 12 & Nov-09 & 1.87 & 482.22 \\
\hline 12 & Nov-09 & 1.85 & 482.04 \\
\hline 12 & Nov-09 & 1.78 & 482.00 \\
\hline 12 & Nov-09 & 1.73 & 481.93 \\
\hline 12 & Nov-09 & 1.70 & 481.82 \\
\hline 12 & Nov-09 & 1.51 & 481.73 \\
\hline 12 & Nov-09 & 1.39 & 481.62 \\
\hline 12 & Nov-09 & 1.25 & 481.52 \\
\hline 12 & Nov-09 & 1.03 & 481.37 \\
\hline 12 & Nov-09 & 1.04 & 481.37 \\
\hline 12 & Nov-09 & 0.90 & 481.28 \\
\hline 12 & Nov-09 & 0.79 & 481.20 \\
\hline 12 & Nov-09 & 0.73 & 481.15 \\
\hline 12 & Nov-09 & 0.71 & 481.07 \\
\hline 12 & Nov-09 & 0.62 & 480.97 \\
\hline 12 & Nov-09 & 0.00 & 480.76 \\
\hline 12 & Oct-10 & 4.02 & 482.61 \\
\hline 12 & Oct-10 & 2.76 & 482.53 \\
\hline 12 & Oct-10 & 2.35 & 482.51 \\
\hline 12 & Oct-10 & 1.88 & 482.49 \\
\hline 12 & Oct-10 & 1.90 & 482.42 \\
\hline 12 & Oct-10 & 1.96 & 482.38 \\
\hline 12 & Oct-10 & 1.90 & 482.31 \\
\hline 12 & Oct-10 & 1.82 & 482.24 \\
\hline 12 & Oct-10 & 1.91 & 482.17 \\
\hline 12 & Oct-10 & 1.88 & 482.11 \\
\hline 12 & Oct-10 & 1.79 & 481.89 \\
\hline 12 & Oct-10 & 1.75 & 481.82 \\
\hline 12 & Oct-10 & 1.74 & 481.76 \\
\hline 12 & Oct-10 & 1.69 & 481.71 \\
\hline 12 & Oct-10 & 1.55 & 481.64 \\
\hline 12 & Oct-10 & 1.43 & 481.56 \\
\hline 12 & Oct-10 & 1.22 & 481.46 \\
\hline 12 & Oct-10 & 1.15 & 481.39 \\
\hline 12 & Oct-10 & 1.12 & 481.34 \\
\hline 12 & Oct-10 & 1.09 & 481.28 \\
\hline 12 & Oct-10 & 1.05 & 481.25 \\
\hline 12 & Oct-10 & 1.04 & 481.19 \\
\hline 12 & Oct-10 & 1.03 & 481.14 \\
\hline 12 & Oct-10 & 1.04 & 481.11 \\
\hline 12 & Oct-10 & 1.03 & 481.08 \\
\hline 12 & Oct-10 & 0.98 & 480.99 \\
\hline 12 & Oct-10 & 0.93 & 480.94 \\
\hline 12 & Oct-10 & 0.77 & 480.89 \\
\hline 12 & Oct-10 & -0.82 & 480.70 \\
\hline 12 & Oct-10 & -3.00 & 480.63 \\
\hline
\end{tabular}




\begin{tabular}{|c|c|c|c|}
\hline Bank Site & Date & Station (m) & Elevation $(\mathrm{m})$ \\
\hline 13 & Nov-09 & 0.00 & 481.22 \\
\hline 13 & Nov-09 & 1.31 & 481.16 \\
\hline 13 & Nov-09 & 1.90 & 480.97 \\
\hline 13 & Nov-09 & 2.26 & 480.88 \\
\hline 13 & Nov-09 & 2.53 & 480.84 \\
\hline 13 & Nov-09 & 2.82 & 480.82 \\
\hline 13 & Nov-09 & 3.11 & 480.69 \\
\hline 13 & Nov-09 & 3.17 & 480.24 \\
\hline 13 & Nov-09 & 3.36 & 480.59 \\
\hline 13 & Nov-09 & 3.68 & 480.52 \\
\hline 13 & Nov-09 & 3.69 & 480.46 \\
\hline 13 & Nov-09 & 3.82 & 480.34 \\
\hline 13 & Nov-09 & 3.98 & 480.36 \\
\hline 13 & Nov-09 & 4.11 & 480.32 \\
\hline 13 & Nov-09 & 4.26 & 480.33 \\
\hline 13 & Oct-10 & 0.00 & 481.22 \\
\hline 13 & Oct-10 & 1.29 & 481.16 \\
\hline 13 & Oct-10 & 1.33 & 481.04 \\
\hline 13 & Oct-10 & 2.00 & 480.92 \\
\hline 13 & Oct-10 & 2.46 & 480.84 \\
\hline 13 & Oct-10 & 2.63 & 480.82 \\
\hline 13 & Oct-10 & 2.58 & 480.72 \\
\hline 13 & Oct-10 & 2.60 & 480.68 \\
\hline 13 & Oct-10 & 2.58 & 480.63 \\
\hline 13 & Oct-10 & 2.56 & 480.59 \\
\hline 13 & Oct-10 & 2.58 & 480.56 \\
\hline 13 & Oct-10 & 2.71 & 480.50 \\
\hline 13 & Oct-10 & 2.77 & 480.44 \\
\hline 13 & Oct-10 & 2.84 & 480.38 \\
\hline 13 & Oct-10 & 3.35 & 480.33 \\
\hline 13 & Oct-10 & 3.68 & 480.29 \\
\hline 13 & Oct-10 & 5.34 & 480.10 \\
\hline 13 & Oct-10 & 6.72 & 480.11 \\
\hline
\end{tabular}




\begin{tabular}{llll} 
Bank Site & Date & Station $(\mathbf{m})$ & Elevation $(\mathbf{m})$ \\
\hline 14 & Nov-09 & 0.00 & 481.43 \\
14 & Nov-09 & 1.68 & 481.37 \\
14 & Nov-09 & 2.63 & 481.33 \\
14 & Nov-09 & 3.16 & 481.29 \\
14 & Nov-09 & 3.12 & 481.27 \\
14 & Nov-09 & 3.13 & 481.23 \\
14 & Nov-09 & 3.07 & 481.13 \\
14 & Nov-09 & 3.07 & 481.08 \\
14 & Nov-09 & 3.10 & 481.01 \\
14 & Nov-09 & 3.33 & 480.89 \\
14 & Nov-09 & 3.50 & 480.77 \\
14 & Nov-09 & 3.73 & 480.64 \\
14 & Nov-09 & 4.03 & 480.43 \\
14 & Nov-09 & 4.25 & 480.30 \\
14 & Nov-09 & 4.55 & 480.25 \\
14 & Nov-09 & 4.76 & 480.18 \\
14 & Nov-09 & 4.93 & 479.82 \\
14 & Nov-09 & 5.20 & 480.07 \\
14 & Oct-10 & 0.00 & 481.43 \\
14 & Oct-10 & 1.69 & 481.37 \\
14 & Oct-10 & 2.45 & 481.32 \\
14 & Oct-10 & 2.99 & 481.27 \\
14 & Oct-10 & 3.00 & 481.20 \\
14 & Oct-10 & 3.06 & 481.01 \\
14 & Oct-10 & 3.15 & 480.95 \\
14 & Oct-10 & 3.37 & 480.91 \\
14 & Oct-10 & 3.50 & 480.78 \\
14 & Oct-10 & 3.60 & 480.67 \\
14 & Oct-10 & 3.77 & 480.57 \\
14 & Oct-10 & 3.89 & 480.44 \\
14 & Oct-10 & 4.12 & 480.27 \\
14 & Oct-10 & 4.49 & 480.21 \\
14 & Oct-10 & 4.76 & 479.97 \\
14 & Oct-10 & 4.80 & 479.68 \\
14 & Oct-10 & 5.65 & 479.63 \\
14 & Oct-10 & 6.07 & 479.52 \\
14 & Oct-10 & 6.37 & 479.51 \\
14 & Oct-10 & 6.60 & 479.42 \\
14 & Oct-10 & 6.89 & 479.37 \\
14 & Oct-10 & 7.31 & 479.35 \\
14 & Oct-10 & 7.67 & 479.28 \\
14 & Oct-10 & 8.10 & 479.21 \\
14 & Oct-10 & 11.01 & 479.21 \\
& & &
\end{tabular}




\begin{tabular}{|c|c|c|c|}
\hline Bank Site & Date & Station (m) & Elevation (m) \\
\hline 15 & Nov-09 & 0.00 & 480.51 \\
\hline 15 & Nov-09 & 1.55 & 480.35 \\
\hline 15 & Nov-09 & 2.81 & 480.24 \\
\hline 15 & Nov-09 & 2.99 & 480.22 \\
\hline 15 & Nov-09 & 3.12 & 480.18 \\
\hline 15 & Nov-09 & 3.07 & 480.17 \\
\hline 15 & Nov-09 & 3.09 & 480.14 \\
\hline 15 & Nov-09 & 3.10 & 480.10 \\
\hline 15 & Nov-09 & 3.09 & 480.07 \\
\hline 15 & Nov-09 & 3.02 & 480.04 \\
\hline 15 & Nov-09 & 3.07 & 480.02 \\
\hline 15 & Nov-09 & 3.06 & 479.98 \\
\hline 15 & Nov-09 & 3.09 & 479.95 \\
\hline 15 & Nov-09 & 3.16 & 479.90 \\
\hline 15 & Nov-09 & 3.18 & 479.84 \\
\hline 15 & Nov-09 & 3.40 & 479.74 \\
\hline 15 & Nov-09 & 3.54 & 479.70 \\
\hline 15 & Nov-09 & 3.64 & 479.65 \\
\hline 15 & Nov-09 & 3.83 & 479.61 \\
\hline 15 & Nov-09 & 3.97 & 479.59 \\
\hline 15 & Nov-09 & 4.48 & 479.53 \\
\hline 15 & Oct-10 & 0.00 & 480.51 \\
\hline 15 & Oct-10 & 1.54 & 480.37 \\
\hline 15 & Oct-10 & 2.06 & 480.35 \\
\hline 15 & Oct-10 & 2.44 & 480.30 \\
\hline 15 & Oct-10 & 2.62 & 480.25 \\
\hline 15 & Oct-10 & 2.65 & 480.17 \\
\hline 15 & Oct-10 & 2.58 & 480.14 \\
\hline 15 & Oct-10 & 2.48 & 479.97 \\
\hline 15 & Oct-10 & 2.48 & 479.94 \\
\hline 15 & Oct-10 & 2.37 & 479.88 \\
\hline 15 & Oct-10 & 2.29 & 479.84 \\
\hline 15 & Oct-10 & 2.23 & 479.82 \\
\hline 15 & Oct-10 & 2.25 & 479.78 \\
\hline 15 & Oct-10 & 2.26 & 479.68 \\
\hline 15 & Oct-10 & 2.33 & 479.59 \\
\hline 15 & Oct-10 & 2.38 & 479.47 \\
\hline 15 & Oct-10 & 2.46 & 479.42 \\
\hline 15 & Oct-10 & 2.59 & 479.35 \\
\hline 15 & Oct-10 & 2.70 & 479.27 \\
\hline 15 & Oct-10 & 2.79 & 479.20 \\
\hline 15 & Oct-10 & 2.89 & 479.18 \\
\hline 15 & Oct-10 & 3.17 & 479.10 \\
\hline 15 & Oct-10 & 3.27 & 478.84 \\
\hline 15 & Oct-10 & 7.34 & 478.75 \\
\hline
\end{tabular}




\begin{tabular}{|c|c|c|c|}
\hline Bank Site & Date & Station (m) & Elevation (m) \\
\hline 16 & Nov-09 & 0.18 & 480.74 \\
\hline 16 & Nov-09 & 0.49 & 480.68 \\
\hline 16 & Nov-09 & 1.10 & 480.69 \\
\hline 16 & Nov-09 & 2.13 & 480.68 \\
\hline 16 & Nov-09 & 3.35 & 480.67 \\
\hline 16 & Nov-09 & 4.57 & 480.53 \\
\hline 16 & Nov-09 & 6.10 & 480.48 \\
\hline 16 & Nov-09 & 6.83 & 480.47 \\
\hline 16 & Nov-09 & 7.35 & 480.33 \\
\hline 16 & Nov-09 & 7.83 & 480.29 \\
\hline 16 & Nov-09 & 8.41 & 480.16 \\
\hline 16 & Nov-09 & 8.90 & 480.11 \\
\hline 16 & Nov-09 & 9.54 & 480.05 \\
\hline 16 & Nov-09 & 10.21 & 479.93 \\
\hline 16 & Nov-09 & 10.82 & 479.84 \\
\hline 16 & Nov-09 & 11.73 & 479.69 \\
\hline 16 & Nov-09 & 12.47 & 479.63 \\
\hline 16 & Nov-09 & 13.41 & 479.55 \\
\hline 16 & Nov-09 & 14.11 & 479.48 \\
\hline 16 & Nov-09 & 14.87 & 479.39 \\
\hline 16 & Nov-09 & 15.24 & 479.36 \\
\hline 16 & Nov-09 & 15.82 & 479.29 \\
\hline 16 & Nov-09 & 16.31 & 479.29 \\
\hline 16 & Nov-09 & 16.92 & 479.27 \\
\hline 16 & Nov-09 & 17.25 & 479.18 \\
\hline 16 & Nov-09 & 17.74 & 479.06 \\
\hline 16 & Nov-09 & 18.59 & 479.02 \\
\hline 16 & Oct-10 & 0.18 & 480.74 \\
\hline 16 & Oct-10 & 0.55 & 480.68 \\
\hline 16 & Oct-10 & 1.37 & 480.68 \\
\hline 16 & Oct-10 & 2.83 & 480.67 \\
\hline 16 & Oct-10 & 3.90 & 480.59 \\
\hline 16 & Oct-10 & 5.12 & 480.51 \\
\hline 16 & Oct-10 & 6.04 & 480.52 \\
\hline 16 & Oct-10 & 6.80 & 480.47 \\
\hline 16 & Oct-10 & 7.56 & 480.32 \\
\hline 16 & Oct-10 & 7.99 & 480.28 \\
\hline 16 & Oct-10 & 8.47 & 480.18 \\
\hline 16 & Oct-10 & 8.78 & 480.15 \\
\hline 16 & Oct-10 & 9.39 & 480.07 \\
\hline 16 & Oct-10 & 10.30 & 479.91 \\
\hline 16 & Oct-10 & 10.91 & 479.83 \\
\hline 16 & Oct-10 & 11.52 & 479.74 \\
\hline 16 & Oct-10 & 12.13 & 479.68 \\
\hline 16 & Oct-10 & 12.59 & 479.61 \\
\hline 16 & Oct-10 & 13.05 & 479.56 \\
\hline 16 & Oct-10 & 13.23 & 479.53 \\
\hline 16 & Oct-10 & 13.35 & 479.49 \\
\hline 16 & Oct-10 & 13.59 & 479.30 \\
\hline 16 & Oct-10 & 13.72 & 479.32 \\
\hline 16 & Oct-10 & 13.87 & 479.23 \\
\hline 16 & Oct-10 & 14.11 & 479.19 \\
\hline 16 & Oct-10 & 14.23 & 479.08 \\
\hline 16 & Oct-10 & 14.57 & 478.96 \\
\hline 16 & Oct-10 & 15.27 & 478.71 \\
\hline 16 & Oct-10 & 17.01 & 478.41 \\
\hline 16 & Oct-10 & 18.53 & 478.58 \\
\hline 16 & Oct-10 & 20.97 & 478.78 \\
\hline 16 & Oct-10 & 22.56 & 479.01 \\
\hline 16 & Oct-10 & 24.63 & 479.00 \\
\hline
\end{tabular}




\begin{tabular}{|c|c|c|c|}
\hline Bank Site & Date & Station (m) & Elevation (m) \\
\hline 17 & Nov-09 & 0.03 & 480.27 \\
\hline 17 & Nov-09 & 1.22 & 480.25 \\
\hline 17 & Nov-09 & 2.71 & 480.30 \\
\hline 17 & Nov-09 & 3.96 & 480.30 \\
\hline 17 & Nov-09 & 4.56 & 480.34 \\
\hline 17 & Nov-09 & 5.30 & 480.30 \\
\hline 17 & Nov-09 & 6.49 & 480.30 \\
\hline 17 & Nov-09 & 7.07 & 480.29 \\
\hline 17 & Nov-09 & 7.38 & 480.24 \\
\hline 17 & Nov-09 & 7.74 & 480.13 \\
\hline 17 & Nov-09 & 8.20 & 479.93 \\
\hline 17 & Nov-09 & 8.53 & 479.80 \\
\hline 17 & Nov-09 & 8.93 & 479.63 \\
\hline 17 & Nov-09 & 9.39 & 479.50 \\
\hline 17 & Nov-09 & 9.88 & 479.31 \\
\hline 17 & Nov-09 & 10.21 & 479.22 \\
\hline 17 & Nov-09 & 10.76 & 479.09 \\
\hline 17 & Nov-09 & 11.37 & 478.99 \\
\hline 17 & Nov-09 & 11.73 & 478.95 \\
\hline 17 & Nov-09 & 12.16 & 478.97 \\
\hline 17 & Nov-09 & 12.74 & 479.00 \\
\hline 17 & Nov-09 & 12.50 & 478.94 \\
\hline 17 & Nov-09 & 12.86 & 478.86 \\
\hline 17 & Nov-09 & 14.02 & 478.71 \\
\hline 17 & Oct-10 & 0.03 & 480.27 \\
\hline 17 & Oct-10 & 0.49 & 480.26 \\
\hline 17 & Oct-10 & 1.40 & 480.27 \\
\hline 17 & Oct-10 & 2.62 & 480.28 \\
\hline 17 & Oct-10 & 3.54 & 480.30 \\
\hline 17 & Oct-10 & 4.25 & 480.36 \\
\hline 17 & Oct-10 & 4.60 & 480.32 \\
\hline 17 & Oct-10 & 5.21 & 480.31 \\
\hline 17 & Oct-10 & 6.13 & 480.29 \\
\hline 17 & Oct-10 & 6.80 & 480.33 \\
\hline 17 & Oct-10 & 7.01 & 480.32 \\
\hline 17 & Oct-10 & 7.19 & 480.27 \\
\hline 17 & Oct-10 & 7.50 & 480.19 \\
\hline 17 & Oct-10 & 7.74 & 480.12 \\
\hline 17 & Oct-10 & 7.96 & 480.01 \\
\hline 17 & Oct-10 & 8.41 & 479.82 \\
\hline 17 & Oct-10 & 8.72 & 479.73 \\
\hline 17 & Oct-10 & 9.14 & 479.56 \\
\hline 17 & Oct-10 & 9.42 & 479.48 \\
\hline 17 & Oct-10 & 9.78 & 479.41 \\
\hline 17 & Oct-10 & 10.09 & 479.34 \\
\hline 17 & Oct-10 & 10.33 & 479.22 \\
\hline 17 & Oct-10 & 10.61 & 479.15 \\
\hline 17 & Oct-10 & 10.85 & 479.07 \\
\hline 17 & Oct-10 & 11.06 & 478.99 \\
\hline 17 & Oct-10 & 11.31 & 478.90 \\
\hline 17 & Oct-10 & 11.58 & 478.86 \\
\hline 17 & Oct-10 & 11.86 & 478.75 \\
\hline 17 & Oct-10 & 13.59 & 478.54 \\
\hline 17 & Oct-10 & 16.03 & 478.74 \\
\hline 17 & Oct-10 & 18.62 & 478.52 \\
\hline 17 & Oct-10 & 19.32 & 478.44 \\
\hline
\end{tabular}




\begin{tabular}{|c|c|c|c|}
\hline Bank Site & Date & Station (m) & Elevation $(m)$ \\
\hline 18 & Nov-09 & 0.82 & 479.82 \\
\hline 18 & Nov-09 & 1.46 & 479.72 \\
\hline 18 & Nov-09 & 1.80 & 479.74 \\
\hline 18 & Nov-09 & 2.23 & 479.65 \\
\hline 18 & Nov-09 & 2.53 & 479.60 \\
\hline 18 & Nov-09 & 2.87 & 479.52 \\
\hline 18 & Nov-09 & 3.12 & 479.52 \\
\hline 18 & Nov-09 & 3.41 & 479.42 \\
\hline 18 & Nov-09 & 3.89 & 479.36 \\
\hline 18 & Nov-09 & 4.18 & 479.32 \\
\hline 18 & Nov-09 & 4.39 & 479.21 \\
\hline 18 & Nov-09 & 4.72 & 478.96 \\
\hline 18 & Nov-09 & 5.06 & 478.82 \\
\hline 18 & Nov-09 & 5.36 & 478.76 \\
\hline 18 & Nov-09 & 5.64 & 478.55 \\
\hline 18 & Nov-09 & 5.76 & 478.47 \\
\hline 18 & Nov-09 & 6.07 & 478.40 \\
\hline 18 & Nov-09 & 6.22 & 478.36 \\
\hline 18 & Nov-09 & 6.46 & 478.29 \\
\hline 18 & Nov-09 & 7.62 & 478.16 \\
\hline 18 & Oct-10 & 0.82 & 479.82 \\
\hline 18 & Oct-10 & 1.13 & 479.75 \\
\hline 18 & Oct-10 & 1.43 & 479.72 \\
\hline 18 & Oct-10 & 1.68 & 479.73 \\
\hline 18 & Oct-10 & 1.74 & 479.69 \\
\hline 18 & Oct-10 & 1.83 & 479.61 \\
\hline 18 & Oct-10 & 2.13 & 479.40 \\
\hline 18 & Oct-10 & 2.23 & 479.29 \\
\hline 18 & Oct-10 & 2.38 & 479.20 \\
\hline 18 & Oct-10 & 2.59 & 479.16 \\
\hline 18 & Oct-10 & 2.83 & 478.97 \\
\hline 18 & Oct-10 & 3.26 & 478.85 \\
\hline 18 & Oct-10 & 3.57 & 478.78 \\
\hline 18 & Oct-10 & 3.96 & 478.71 \\
\hline 18 & Oct-10 & 4.36 & 478.65 \\
\hline 18 & Oct-10 & 4.94 & 478.53 \\
\hline 18 & Oct-10 & 5.40 & 478.48 \\
\hline 18 & Oct-10 & 5.70 & 478.43 \\
\hline 18 & Oct-10 & 6.07 & 478.35 \\
\hline 18 & Oct-10 & 6.49 & 478.30 \\
\hline 18 & Oct-10 & 7.01 & 478.22 \\
\hline 18 & Oct-10 & 7.53 & 478.15 \\
\hline 18 & Oct-10 & 8.23 & 478.20 \\
\hline 18 & Oct-10 & 8.78 & 478.21 \\
\hline 18 & Oct-10 & 9.27 & 478.20 \\
\hline 18 & Oct-10 & 9.69 & 478.18 \\
\hline 18 & Oct-10 & 9.97 & 478.12 \\
\hline 18 & Oct-10 & 10.30 & 478.05 \\
\hline 18 & Oct-10 & 10.73 & 478.01 \\
\hline 18 & Oct-10 & 11.34 & 477.93 \\
\hline 18 & Oct-10 & 11.80 & 477.84 \\
\hline 18 & Oct-10 & 13.20 & 477.59 \\
\hline
\end{tabular}




\begin{tabular}{|c|c|c|c|}
\hline Bank Site & Date & Station (m) & Elevation (m) \\
\hline 19 & Nov-09 & 8.49 & 480.15 \\
\hline 19 & Nov-09 & 8.35 & 480.03 \\
\hline 19 & Nov-09 & 8.05 & 480.07 \\
\hline 19 & Nov-09 & 7.65 & 479.95 \\
\hline 19 & Nov-09 & 7.28 & 479.89 \\
\hline 19 & Nov-09 & 7.04 & 479.84 \\
\hline 19 & Nov-09 & 6.58 & 479.69 \\
\hline 19 & Nov-09 & 6.13 & 479.53 \\
\hline 19 & Nov-09 & 5.61 & 479.41 \\
\hline 19 & Nov-09 & 5.27 & 479.22 \\
\hline 19 & Nov-09 & 5.09 & 479.12 \\
\hline 19 & Nov-09 & 4.72 & 479.00 \\
\hline 19 & Nov-09 & 4.21 & 478.88 \\
\hline 19 & Nov-09 & 2.99 & 478.75 \\
\hline 19 & Nov-09 & 1.80 & 478.66 \\
\hline 19 & Nov-09 & 0.64 & 478.74 \\
\hline 19 & Nov-09 & 0.00 & 478.76 \\
\hline 19 & Oct-10 & 8.49 & 480.15 \\
\hline 19 & Oct-10 & 8.15 & 480.09 \\
\hline 19 & Oct-10 & 7.88 & 479.98 \\
\hline 19 & Oct-10 & 7.60 & 479.96 \\
\hline 19 & Oct-10 & 7.27 & 479.88 \\
\hline 19 & Oct-10 & 7.01 & 479.84 \\
\hline 19 & Oct-10 & 6.90 & 479.79 \\
\hline 19 & Oct-10 & 6.66 & 479.71 \\
\hline 19 & Oct-10 & 6.42 & 479.62 \\
\hline 19 & Oct-10 & 6.23 & 479.38 \\
\hline 19 & Oct-10 & 5.84 & 479.29 \\
\hline 19 & Oct-10 & 5.41 & 479.10 \\
\hline 19 & Oct-10 & 5.01 & 479.04 \\
\hline 19 & Oct-10 & 4.71 & 478.94 \\
\hline 19 & Oct-10 & 3.95 & 478.78 \\
\hline 19 & Oct-10 & 3.55 & 478.73 \\
\hline 19 & Oct-10 & 3.03 & 478.69 \\
\hline 19 & Oct-10 & 2.73 & 478.70 \\
\hline 19 & Oct-10 & 2.27 & 478.68 \\
\hline 19 & Oct-10 & 1.81 & 478.65 \\
\hline 19 & Oct-10 & 1.63 & 478.77 \\
\hline 19 & Oct-10 & 1.36 & 478.77 \\
\hline 19 & Oct-10 & 1.30 & 478.59 \\
\hline 19 & Oct-10 & 1.14 & 478.59 \\
\hline 19 & Oct-10 & 0.84 & 478.80 \\
\hline 19 & Oct-10 & 0.72 & 478.67 \\
\hline 19 & Oct-10 & 0.44 & 478.68 \\
\hline 19 & Oct-10 & 0.35 & 478.76 \\
\hline 19 & Oct-10 & 0.05 & 478.67 \\
\hline 19 & Oct-10 & -0.17 & 478.76 \\
\hline 19 & Oct-10 & -0.47 & 478.51 \\
\hline 19 & Oct-10 & -0.99 & 478.08 \\
\hline 19 & Oct-10 & -1.11 & 478.21 \\
\hline 19 & Oct-10 & -1.84 & 478.32 \\
\hline 19 & Oct-10 & -2.73 & 478.24 \\
\hline 19 & Oct-10 & -3.22 & 478.08 \\
\hline 19 & Oct-10 & -3.83 & 477.90 \\
\hline 19 & Oct-10 & -5.04 & 477.68 \\
\hline
\end{tabular}




\begin{tabular}{llll} 
Bank Site & Date & Station $(\mathbf{m})$ & Elevation $(\mathbf{m})$ \\
\hline 20 & Nov-09 & 10.06 & 480.02 \\
20 & Nov-09 & 9.17 & 479.90 \\
20 & Nov-09 & 8.56 & 479.91 \\
20 & Nov-09 & 7.92 & 479.74 \\
20 & Nov-09 & 7.16 & 479.52 \\
20 & Nov-09 & 6.52 & 479.44 \\
20 & Nov-09 & 6.00 & 479.33 \\
20 & Nov-09 & 5.27 & 479.15 \\
20 & Nov-09 & 4.36 & 478.97 \\
20 & Nov-09 & 4.08 & 478.80 \\
20 & Nov-09 & 3.41 & 478.60 \\
20 & Nov-09 & 2.65 & 478.39 \\
20 & Nov-09 & 1.83 & 478.31 \\
20 & Nov-09 & 1.31 & 478.21 \\
20 & Nov-09 & 0.79 & 478.06 \\
20 & Nov-09 & 0.00 & 477.85 \\
20 & Oct-10 & 10.06 & 480.02 \\
20 & Oct-10 & 9.72 & 479.93 \\
20 & Oct-10 & 9.27 & 479.90 \\
20 & Oct-10 & 8.66 & 479.89 \\
20 & Oct-10 & 8.35 & 479.86 \\
20 & Oct-10 & 8.05 & 479.78 \\
20 & Oct-10 & 7.59 & 479.65 \\
20 & Oct-10 & 7.16 & 479.52 \\
20 & Oct-10 & 6.83 & 479.47 \\
20 & Oct-10 & 6.49 & 479.41 \\
20 & Oct-10 & 6.19 & 479.34 \\
20 & Oct-10 & 6.02 & 479.32 \\
20 & Oct-10 & 5.91 & 479.25 \\
20 & Oct-10 & 5.61 & 479.19 \\
20 & Oct-10 & 5.49 & 479.06 \\
20 & Oct-10 & 5.15 & 478.86 \\
20 & Oct-10 & 4.69 & 478.72 \\
20 & Oct-10 & 4.39 & 478.62 \\
20 & Oct-10 & 3.69 & 478.44 \\
20 & Oct-10 & 3.35 & 478.27 \\
20 & Oct-10 & 3.08 & 478.16 \\
20 & Oct-10 & 2.87 & 478.01 \\
20 & Oct-10 & 2.26 & 477.95 \\
20 & Oct-10 & 1.92 & 477.91 \\
20 & Oct-10 & 0.88 & 477.83 \\
20 & Oct-10 & -0.49 & 477.61 \\
20 & Oct-10 & -2.01 & 477.57 \\
& & &
\end{tabular}




\begin{tabular}{llll} 
Bank Site & Date & Station $(\mathbf{m})$ & Elevation $(\mathbf{m})$ \\
\hline 21 & Nov-09 & 8.72 & 479.55 \\
21 & Nov-09 & 8.11 & 479.45 \\
21 & Nov-09 & 7.47 & 479.43 \\
21 & Nov-09 & 7.07 & 479.27 \\
21 & Nov-09 & 6.43 & 479.10 \\
21 & Nov-09 & 5.88 & 478.98 \\
21 & Nov-09 & 5.36 & 478.79 \\
21 & Nov-09 & 4.75 & 478.59 \\
21 & Nov-09 & 4.05 & 478.41 \\
21 & Nov-09 & 2.68 & 478.11 \\
21 & Nov-09 & 2.04 & 477.95 \\
21 & Nov-09 & 1.25 & 477.89 \\
21 & Nov-09 & 0.85 & 477.87 \\
21 & Nov-09 & 0.61 & 477.72 \\
21 & Nov-09 & 0.00 & 477.57 \\
21 & Oct-10 & 8.72 & 479.53 \\
21 & Oct-10 & 8.31 & 479.43 \\
21 & Oct-10 & 7.85 & 479.44 \\
21 & Oct-10 & 7.57 & 479.45 \\
21 & Oct-10 & 7.21 & 479.31 \\
21 & Oct-10 & 7.03 & 479.24 \\
21 & Oct-10 & 6.78 & 479.19 \\
21 & Oct-10 & 6.60 & 479.16 \\
21 & Oct-10 & 6.48 & 479.10 \\
21 & Oct-10 & 6.17 & 479.01 \\
21 & Oct-10 & 5.88 & 478.98 \\
21 & Oct-10 & 5.78 & 478.89 \\
21 & Oct-10 & 5.41 & 478.78 \\
21 & Oct-10 & 5.11 & 478.68 \\
21 & Oct-10 & 4.80 & 478.58 \\
21 & Oct-10 & 4.31 & 478.49 \\
21 & Oct-10 & 4.04 & 478.43 \\
21 & Oct-10 & 3.64 & 478.32 \\
21 & Oct-10 & 3.28 & 478.26 \\
21 & Oct-10 & 2.88 & 478.17 \\
21 & Oct-10 & 2.55 & 478.04 \\
21 & Oct-10 & 2.21 & 477.89 \\
21 & Oct-10 & 1.84 & 477.77 \\
21 & Oct-10 & 1.60 & 477.67 \\
21 & Oct-10 & 1.30 & 477.59 \\
21 & Oct-10 & 0.99 & 477.56 \\
21 & Oct-10 & 0.69 & 477.49 \\
21 & Oct-10 & 0.50 & 477.37 \\
21 & Oct-10 & -1.45 & 477.20 \\
& & &
\end{tabular}




\begin{tabular}{|c|c|c|c|}
\hline Bank Site & Date & Station $(m)$ & Elevation (m) \\
\hline 22 & Nov-09 & 0.55 & 478.83 \\
\hline 22 & Nov-09 & 1.04 & 478.79 \\
\hline 22 & Nov-09 & 2.04 & 478.78 \\
\hline 22 & Nov-09 & 2.59 & 478.73 \\
\hline 22 & Nov-09 & 3.29 & 478.83 \\
\hline 22 & Nov-09 & 4.15 & 478.82 \\
\hline 22 & Nov-09 & 4.69 & 478.88 \\
\hline 22 & Nov-09 & 5.43 & 478.73 \\
\hline 22 & Nov-09 & 5.82 & 478.64 \\
\hline 22 & Nov-09 & 6.10 & 478.65 \\
\hline 22 & Nov-09 & 6.77 & 478.42 \\
\hline 22 & Nov-09 & 7.44 & 478.22 \\
\hline 22 & Nov-09 & 7.86 & 478.17 \\
\hline 22 & Nov-09 & 8.23 & 478.06 \\
\hline 22 & Nov-09 & 8.32 & 477.90 \\
\hline 22 & Nov-09 & 8.78 & 477.73 \\
\hline 22 & Nov-09 & 9.24 & 477.61 \\
\hline 22 & Nov-09 & 9.57 & 477.60 \\
\hline 22 & Nov-09 & 9.66 & 477.48 \\
\hline 22 & Nov-09 & 10.09 & 477.41 \\
\hline 22 & Nov-09 & 10.52 & 477.32 \\
\hline 22 & Nov-09 & 12.19 & 477.06 \\
\hline 22 & Oct-10 & 0.55 & 478.83 \\
\hline 22 & Oct-10 & 1.02 & 478.79 \\
\hline 22 & Oct-10 & 1.63 & 478.81 \\
\hline 22 & Oct-10 & 2.24 & 478.77 \\
\hline 22 & Oct-10 & 2.70 & 478.82 \\
\hline 22 & Oct-10 & 3.00 & 478.83 \\
\hline 22 & Oct-10 & 3.46 & 478.85 \\
\hline 22 & Oct-10 & 4.07 & 478.82 \\
\hline 22 & Oct-10 & 4.68 & 478.87 \\
\hline 22 & Oct-10 & 5.14 & 478.81 \\
\hline 22 & Oct-10 & 5.44 & 478.75 \\
\hline 22 & Oct-10 & 5.75 & 478.66 \\
\hline 22 & Oct-10 & 6.13 & 478.65 \\
\hline 22 & Oct-10 & 6.32 & 478.56 \\
\hline 22 & Oct-10 & 6.51 & 478.51 \\
\hline 22 & Oct-10 & 6.63 & 478.46 \\
\hline 22 & Oct-10 & 6.72 & 478.37 \\
\hline 22 & Oct-10 & 6.90 & 478.27 \\
\hline 22 & Oct-10 & 7.00 & 478.21 \\
\hline 22 & Oct-10 & 7.15 & 478.10 \\
\hline 22 & Oct-10 & 7.36 & 478.04 \\
\hline 22 & Oct-10 & 7.57 & 478.00 \\
\hline 22 & Oct-10 & 7.67 & 477.94 \\
\hline 22 & Oct-10 & 7.79 & 477.88 \\
\hline 22 & Oct-10 & 7.88 & 477.76 \\
\hline 22 & Oct-10 & 8.18 & 477.69 \\
\hline 22 & Oct-10 & 8.46 & 477.63 \\
\hline 22 & Oct-10 & 8.76 & 477.61 \\
\hline 22 & Oct-10 & 8.89 & 477.52 \\
\hline 22 & Oct-10 & 9.16 & 477.51 \\
\hline 22 & Oct-10 & 9.40 & 477.47 \\
\hline 22 & Oct-10 & 9.56 & 477.50 \\
\hline 22 & Oct-10 & 9.68 & 477.38 \\
\hline 22 & Oct-10 & 9.86 & 477.33 \\
\hline 22 & Oct-10 & 10.17 & 477.25 \\
\hline 22 & Oct-10 & 10.47 & 477.24 \\
\hline 22 & Oct-10 & 10.90 & 477.21 \\
\hline 22 & Oct-10 & 11.05 & 477.16 \\
\hline 22 & Oct-10 & 11.84 & 477.10 \\
\hline 22 & Oct-10 & 12.76 & 477.07 \\
\hline 22 & Oct-10 & 14.58 & 477.35 \\
\hline 22 & Oct-10 & 15.65 & 476.73 \\
\hline
\end{tabular}




\begin{tabular}{llll} 
Bank Site & Date & Station $(\mathbf{m})$ & Elevation $(\mathbf{m})$ \\
\hline 23 & Nov-09 & 0.55 & 478.79 \\
23 & Nov-09 & 1.34 & 478.61 \\
23 & Nov-09 & 2.53 & 478.76 \\
23 & Nov-09 & 3.17 & 478.71 \\
23 & Nov-09 & 3.66 & 478.61 \\
23 & Nov-09 & 3.87 & 478.37 \\
23 & Nov-09 & 4.33 & 478.10 \\
23 & Nov-09 & 4.69 & 477.94 \\
23 & Nov-09 & 5.36 & 477.78 \\
23 & Nov-09 & 5.64 & 477.53 \\
23 & Nov-09 & 6.34 & 477.44 \\
23 & Nov-09 & 6.71 & 477.38 \\
23 & Nov-09 & 6.83 & 477.29 \\
23 & Nov-09 & 7.28 & 477.22 \\
23 & Nov-09 & 7.50 & 477.16 \\
23 & Nov-09 & 8.29 & 477.04 \\
23 & Nov-09 & 9.45 & 476.94 \\
23 & Oct-10 & 0.55 & 478.80 \\
23 & Oct-10 & 0.96 & 478.66 \\
23 & Oct-10 & 1.57 & 478.66 \\
23 & Oct-10 & 2.03 & 478.73 \\
23 & Oct-10 & 2.55 & 478.76 \\
23 & Oct-10 & 2.79 & 478.71 \\
23 & Oct-10 & 3.03 & 478.71 \\
23 & Oct-10 & 3.22 & 478.69 \\
23 & Oct-10 & 3.34 & 478.68 \\
23 & Oct-10 & 3.49 & 478.57 \\
23 & Oct-10 & 3.76 & 478.37 \\
23 & Oct-10 & 3.95 & 478.25 \\
23 & Oct-10 & 4.19 & 478.16 \\
23 & Oct-10 & 4.40 & 477.99 \\
23 & Oct-10 & 4.62 & 477.82 \\
23 & Oct-10 & 4.92 & 477.67 \\
23 & Oct-10 & 5.23 & 477.56 \\
23 & Oct-10 & 5.53 & 477.42 \\
23 & Oct-10 & 5.84 & 477.40 \\
23 & Oct-10 & 6.14 & 477.36 \\
23 & Oct-10 & 6.26 & 477.45 \\
23 & Oct-10 & 6.60 & 477.30 \\
23 & Oct-10 & 6.63 & 477.21 \\
23 & Oct-10 & 6.96 & 477.16 \\
23 & Oct-10 & 7.51 & 477.07 \\
23 & Oct-10 & 8.28 & 476.84 \\
& Oct-10 & 12.39 & 477.02 \\
& & &
\end{tabular}




\begin{tabular}{llll} 
Bank Site & Date & Station $(\mathbf{m})$ & Elevation $(\mathbf{m})$ \\
\hline 24 & Nov-09 & 5.79 & 478.07 \\
24 & Nov-09 & 5.06 & 477.97 \\
24 & Nov-09 & 4.63 & 478.03 \\
24 & Nov-09 & 4.24 & 477.97 \\
24 & Nov-09 & 3.81 & 477.75 \\
24 & Nov-09 & 3.38 & 477.62 \\
24 & Nov-09 & 2.90 & 477.50 \\
24 & Nov-09 & 2.65 & 477.32 \\
24 & Nov-09 & 2.41 & 477.22 \\
24 & Nov-09 & 2.35 & 477.11 \\
24 & Nov-09 & 1.68 & 477.00 \\
24 & Nov-09 & 1.22 & 476.91 \\
24 & Nov-09 & 0.91 & 476.80 \\
24 & Nov-09 & 0.00 & 476.60 \\
24 & Oct-10 & 5.79 & 478.07 \\
24 & Oct-10 & 5.50 & 478.06 \\
24 & Oct-10 & 5.04 & 477.97 \\
24 & Oct-10 & 4.65 & 478.03 \\
24 & Oct-10 & 4.43 & 477.98 \\
24 & Oct-10 & 4.28 & 477.96 \\
24 & Oct-10 & 4.13 & 477.90 \\
24 & Oct-10 & 3.83 & 477.83 \\
24 & Oct-10 & 3.52 & 477.64 \\
24 & Oct-10 & 3.22 & 477.56 \\
24 & Oct-10 & 3.06 & 477.49 \\
24 & Oct-10 & 2.76 & 477.49 \\
24 & Oct-10 & 2.70 & 477.34 \\
24 & Oct-10 & 2.30 & 477.19 \\
24 & Oct-10 & 2.00 & 477.16 \\
24 & Oct-10 & 1.84 & 477.08 \\
24 & Oct-10 & 1.54 & 476.99 \\
24 & Oct-10 & 1.36 & 476.94 \\
24 & Oct-10 & 1.23 & 476.95 \\
24 & Oct-10 & 1.17 & 476.87 \\
24 & Oct-10 & 0.93 & 476.81 \\
24 & Oct-10 & 0.87 & 476.78 \\
24 & Oct-10 & 0.32 & 476.75 \\
24 & Oct-10 & -0.59 & 476.62 \\
24 & Oct-10 & -2.12 & 476.83 \\
& & &
\end{tabular}




\section{Appendix C: BEHI input geometry worksheet for streambank sites}

Option A - Draw a detailed bank profile using the boxes below

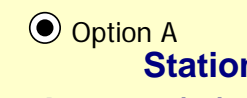

Point (m)

A $\quad-30.00$

B $\quad 1.93$

C $\quad 1.91$

D $\quad 1.82$

E $\quad 1.72$

F $\quad 1.59$

G $\quad 1.27$

H $\quad 1.14$

I 1.12

J $\quad 1.28$

K $\quad 1.36$

L $\quad 1.48$

M $\quad 1.53$

N $\quad 1.54$

O $\quad 1.51$

P $\quad 1.51$

Q $\quad 1.49$

R $\quad 1.55$

$\mathrm{S} \quad 1.61$

$\mathrm{T} \quad 1.65$

U $\quad 1.69$

$\begin{array}{ll}V & 2.07\end{array}$

W $\quad 5.15$

Elevation

(m)

486.54 toe?

486.54

486.49

486.42

486.29

486.13

486.09

485.99

485.93

485.87

485.80

485.76

485.68

485.63

485.41

485.32

485.16

485.10

485.06

485.01

484.96

484.83

484.28

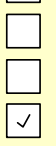

Option B - Enter a bank height and angle, the model will generate a bank profile

Option B

a) Input bank height (m)

b) Input bank angle $\left(^{\circ}\right)$

c) Input bank toe length (m)

d) Input bank toe angle $\left(^{\circ}\right)$

$\square$ Input shear surface angle

Bank layer thickness (m)

Shear emergence elev

Shear surface angle

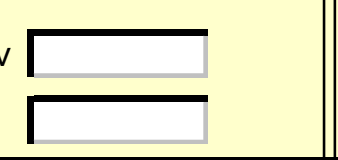

Elevation of layer base $(\mathrm{m})$
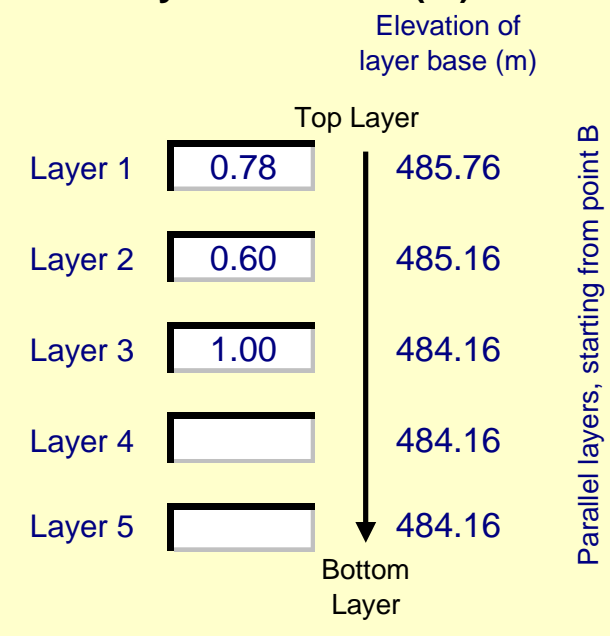


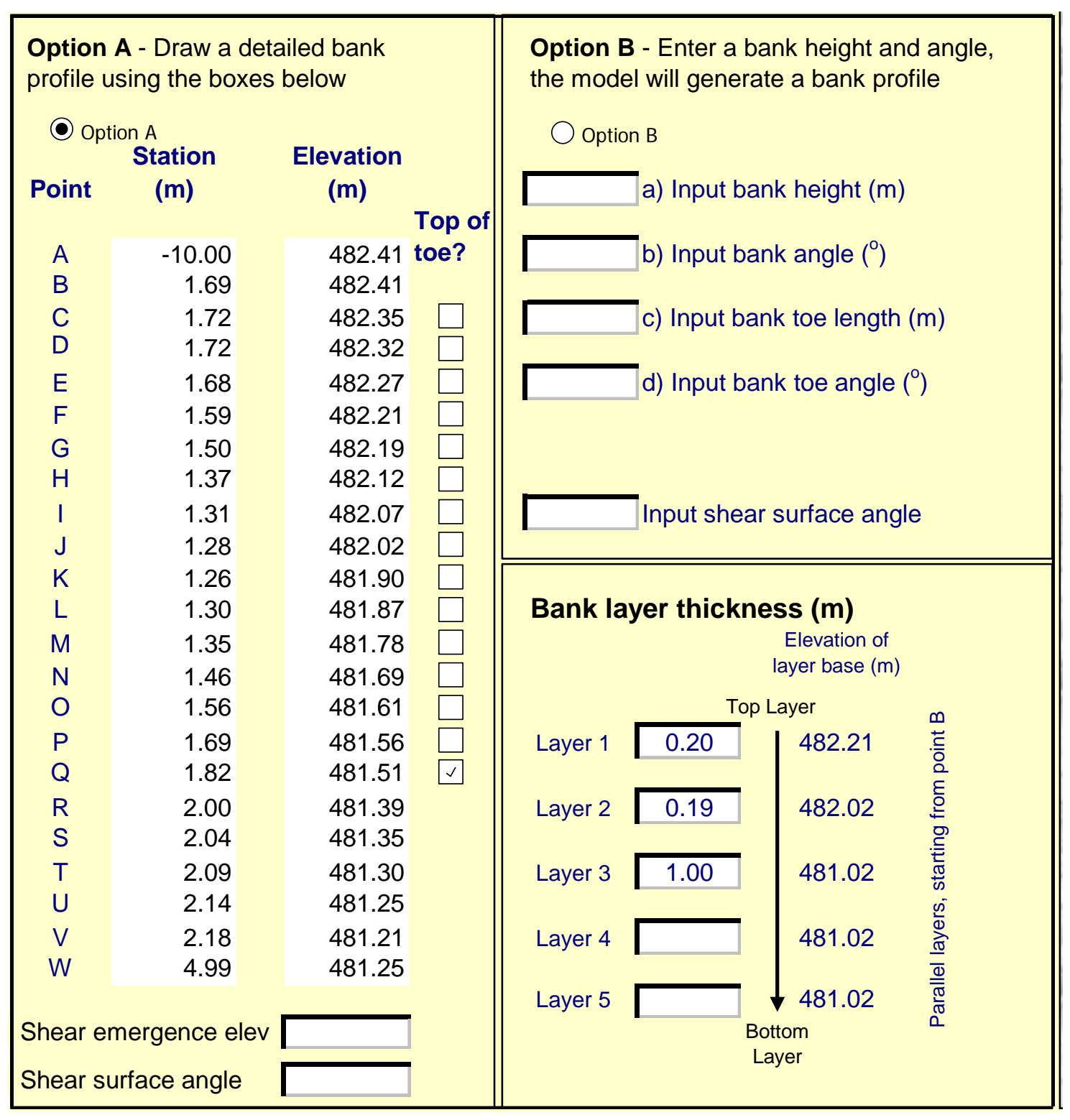




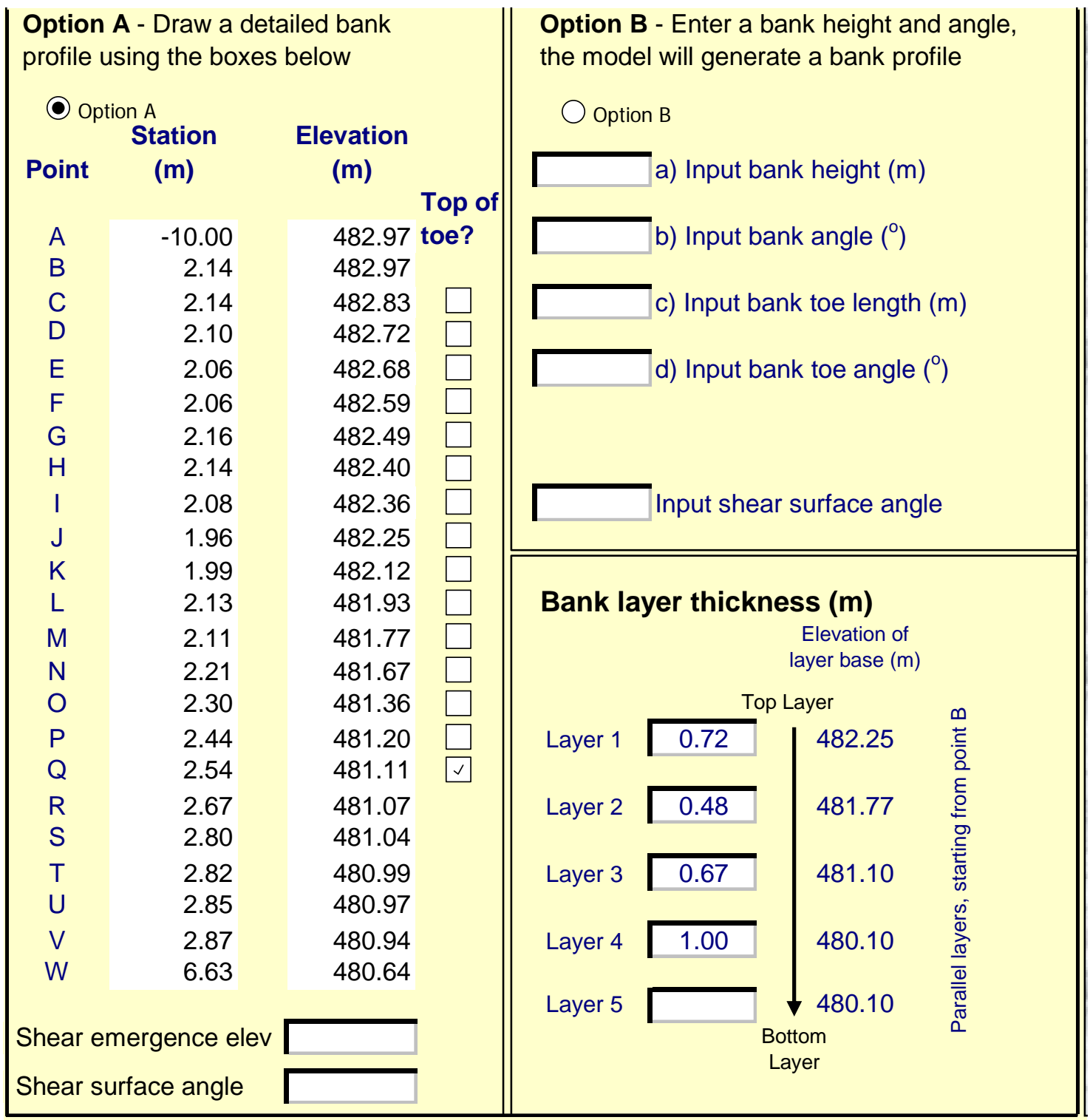




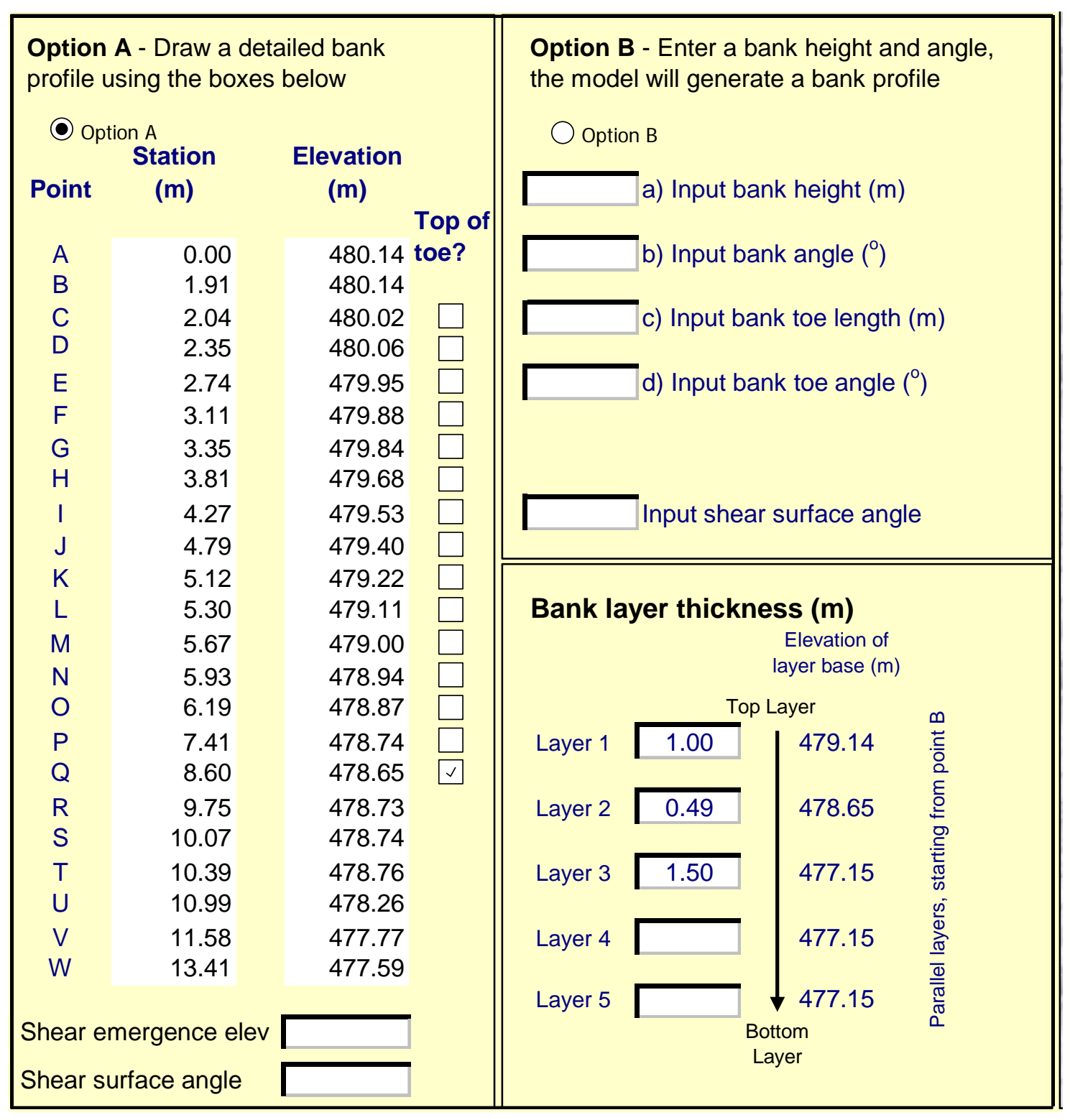




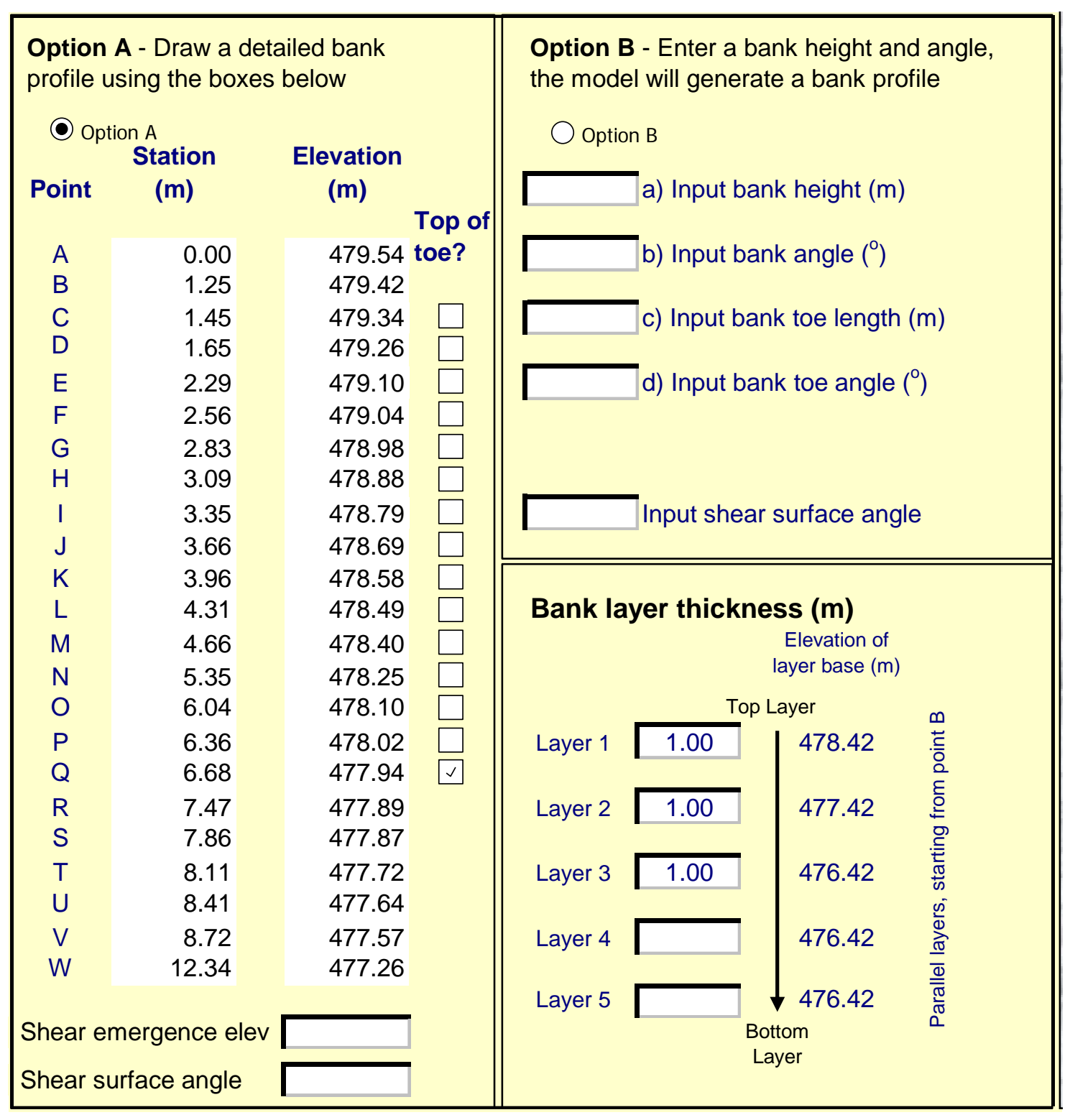




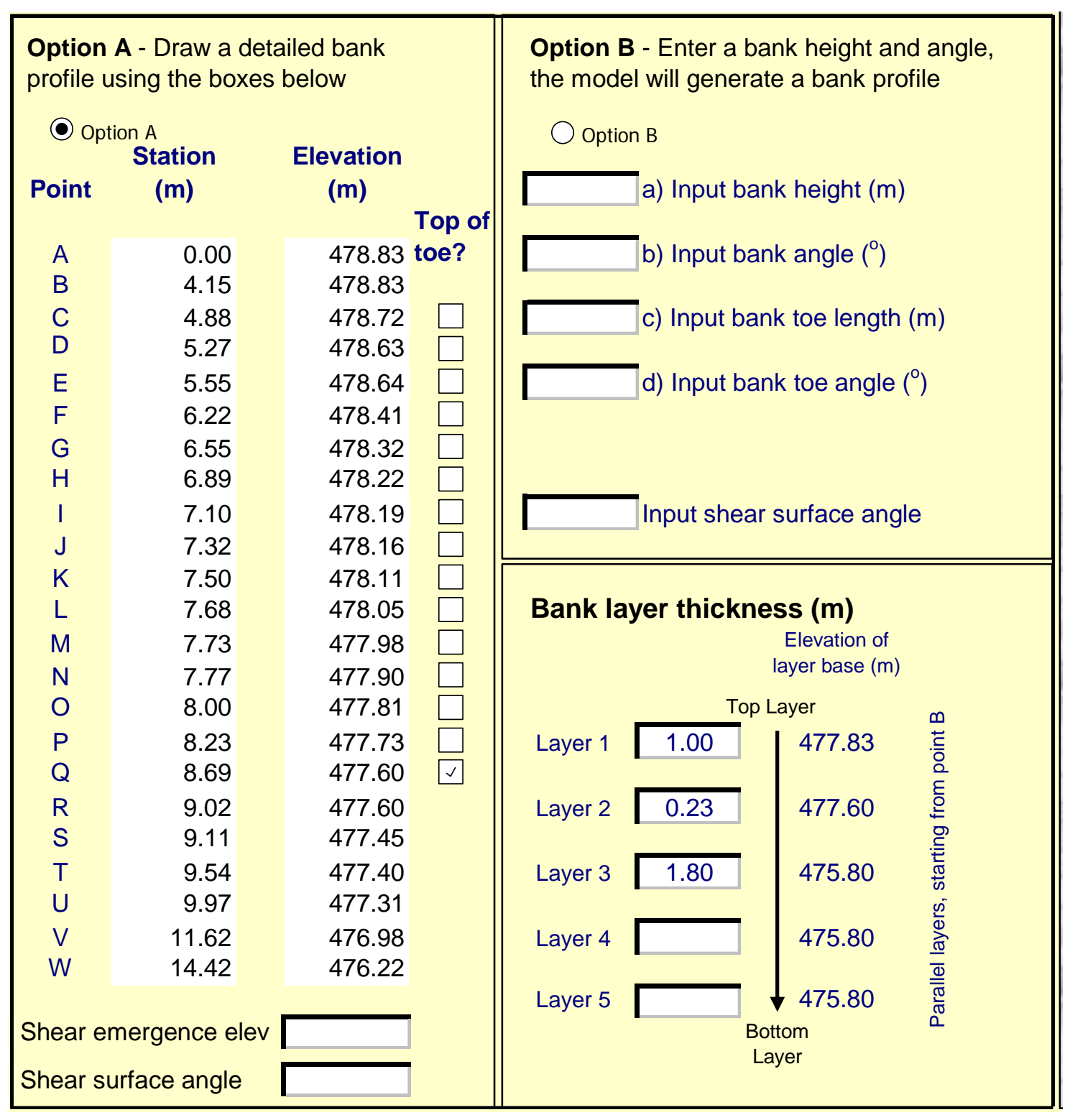


Appendix D: Streambank soil texture analysis results by layer

\begin{tabular}{ccccccc} 
Bank Site & Layer & depth $(\mathrm{m})$ & \%gravel & \%sand & \%silt & \%clay \\
\hline 1 & 1 & 0.78 & 3 & 42 & 23 & 32 \\
1 & 2 & 0.68 & 79 & 14 & 2 & 5 \\
2 & 1 & 0.59 & 0 & 42 & 23 & 35 \\
2 & 2 & 0.41 & 39 & 38 & 9 & 14 \\
2 & 3 & 0.53 & 1 & 59 & 15 & 26 \\
3 & 1 & 0.45 & 0 & 43 & 19 & 37 \\
3 & 2 & 0.27 & 0 & 47 & 21 & 32 \\
4 & 1 & 0.16 & 0 & 39 & 16 & 45 \\
5 & 1 & 0.34 & 84 & 13 & 1 & 2 \\
6 & 1 & 0.1 & 63 & 27 & 2 & 8 \\
7 & 1 & 0.66 & 63 & 27 & 2 & 8 \\
8 & 1 & 0.51 & 67 & 20 & 4 & 10 \\
9 & 1 & 0.2 & 0 & 39 & 19 & 42 \\
9 & 2 & 0.19 & 82 & 14 & 1 & 3 \\
10 & 1 & 0.51 & 33 & 52 & 5 & 10 \\
11 & 1 & 0.72 & 71 & 22 & 2 & 5 \\
11 & 2 & 0.48 & 88 & 9 & 1 & 2 \\
11 & 3 & 0.67 & 76 & 21 & 1 & 2 \\
12 & 1 & 0.88 & 2 & 39 & 26 & 33 \\
12 & 2 & 0.42 & 88 & 9 & 1 & 2 \\
13 & 1 & 0.58 & 0 & 59 & 12 & 28 \\
14 & 1 & 0.4 & 0 & 47 & 20 & 32 \\
15 & 1 & 0.16 & 10 & 55 & 10 & 24
\end{tabular}


Appendix E: Streambank site location (NAD 1983 StatePlane West Virginia North FIPS 4701 Ft)

\begin{tabular}{ccc} 
Site & $\mathbf{X}$ & $\mathbf{Y}$ \\
\hline 1 & 1927567.578 & 241719.7757 \\
2 & 1927540.559 & 241701.2796 \\
3 & 1927439.401 & 241464.3025 \\
4 & 1927514.655 & 241107.1257 \\
5 & 1927046.964 & 240871.2014 \\
6 & 1926978.889 & 240856.8997 \\
7 & 1926901.83 & 240855.1821 \\
8 & 1926689.992 & 240885.5305 \\
9 & 1926196.783 & 240800.7089 \\
10 & 1926117.229 & 240762.0701 \\
11 & 1925969.559 & 240635.067 \\
12 & 1925904.446 & 240557.6385 \\
13 & 1925938.727 & 240387.5878 \\
14 & 1925615.71 & 239877.9401 \\
15 & 1925485.065 & 239777.9813 \\
16 & 1925302.349 & 239695.0969 \\
17 & 1925172.073 & 239749.5512 \\
19 & 1924992.986 & 239861.3847 \\
19 & 1924996.218 & 239948.7496 \\
20 & 1924871.402 & 239930.5166 \\
21 & 1924685.718 & 239684.2166 \\
22 & 1924762.149 & 239331.9061 \\
23 & 1924639.996 & 239178.3595 \\
24 & 1924529.333 & 239184.3691
\end{tabular}


Appendix F: Geomorphic Data

\begin{tabular}{|c|c|c|c|c|c|c|c|}
\hline Bank Site & XS Area $\left(m^{2}\right)$ & XS Width (m) & XS Mean Depth $(\mathrm{m})$ & XS Max Depth (m) & Slope & $\mathrm{D} 50(\mathrm{~mm})$ & Radius of Curvature $(\mathrm{m})$ \\
\hline 1 & 88.90 & 78.79 & 1.13 & 2.26 & 0.0054 & 55 & 72 \\
\hline 2 & 80.99 & 73.27 & 1.11 & 2.12 & 0.0054 & 55 & 72 \\
\hline 3 & 68.57 & 60.87 & 1.13 & 2.23 & 0.0059 & 65 & 72 \\
\hline 4 & 45.02 & 61.17 & 0.74 & 1.98 & 0.011 & 57 & 72 \\
\hline 5 & 201.64 & 134.88 & 1.49 & 2.75 & 0.0071 & 55 & 112 \\
\hline 6 & 92.75 & 84.61 & 1.10 & 1.71 & 0.0071 & 50 & 112 \\
\hline 7 & 111.81 & 83.30 & 1.34 & 2.15 & 0.0071 & 50 & 112 \\
\hline 8 & 18.70 & 61.36 & 0.88 & 1.33 & 0.0071 & 61 & 112 \\
\hline 9 & 42.35 & 76.41 & 0.55 & 1.26 & 0.0041 & 50 & 165 \\
\hline 10 & 39.39 & 58.52 & 0.67 & 1.25 & 0.0041 & 50 & 165 \\
\hline 11 & 149.68 & 115.79 & 1.29 & 2.33 & 0.0041 & 54 & 165 \\
\hline 12 & 119.55 & 112.35 & 1.06 & 1.98 & 0.0041 & 54 & 165 \\
\hline 13 & 20.62 & 33.50 & 0.62 & 0.86 & 0.0041 & 40 & 165 \\
\hline 14 & 168.49 & 181.36 & 0.93 & 2.18 & 0.0059 & 47 & 85 \\
\hline 15 & 20.77 & 28.93 & 0.72 & 1.42 & 0.0059 & 47 & 85 \\
\hline 16 & 74.44 & 118.05 & 0.63 & 2.14 & 0.0023 & 55 & 85 \\
\hline 17 & 42.16 & 66.66 & 0.63 & 1.80 & 0.0023 & 55 & 85 \\
\hline 18 & 53.36 & 65.56 & 0.81 & 2.47 & 0.0069 & 60 & 58 \\
\hline 19 & 53.36 & 65.56 & 0.81 & 2.47 & 0.0069 & 60 & 58 \\
\hline 20 & 40.33 & 35.57 & 1.13 & 2.41 & 0.0069 & 79 & 58 \\
\hline 21 & 48.63 & 37.49 & 1.30 & 2.29 & 0.0049 & 79 & 58 \\
\hline 22 & 43.32 & 46.18 & 0.94 & 2.65 & 0.0032 & 86 & 59 \\
\hline 23 & 41.74 & 43.98 & 0.95 & 1.91 & 0.0032 & 63 & 59 \\
\hline 24 & 26.65 & 28.65 & 0.93 & 1.59 & 0.0032 & 63 & 59 \\
\hline
\end{tabular}


Appendix G: BANCS parameter data

Study bank Bankfull Height Root Depth Root Density Bank Angle Surface Bank Material Stratification Near Bank Mean Bankfull

\begin{tabular}{|c|c|c|c|c|c|c|c|c|c|c|c|}
\hline Bank & Reach & height $(\mathrm{m})$ & $(\mathrm{m})$ & $(\mathrm{m})$ & $(\%)$ & (Degrees) & protection (\%) & Adjustment & Adjustment & Max Depth (m) & Depth $(\mathrm{m})$ \\
\hline 1 & Upper & 1.69 & 1.22 & 1.22 & 20 & 136 & 0 & 7 & 10 & 2.40 & 1.49 \\
\hline 2 & Upper & 1.76 & 1.20 & 0.03 & 10 & 96 & 0 & 9 & 8 & 2.31 & 1.46 \\
\hline 3 & Upper & 1.61 & 1.38 & 0.09 & 15 & 87 & 0 & 6 & 5 & 1.65 & 1.18 \\
\hline 4 & Upper & 1.42 & 1.58 & 0.40 & 15 & 34 & 0 & 5 & 8 & 1.68 & 0.81 \\
\hline 5 & Upper & 1.80 & 1.03 & 0.09 & 8 & 49 & 0 & 8 & 5 & 2.33 & 1.88 \\
\hline 6 & Upper & 1.59 & 1.51 & 0.18 & 10 & 37 & 20 & 9 & 5 & 1.25 & 1.28 \\
\hline 7 & Upper & 1.88 & 1.53 & 0.49 & 15 & 30 & 67 & 9 & 5 & 2.10 & 1.62 \\
\hline 8 & Upper & 1.18 & 1.58 & 0.73 & 20 & 124 & 0 & 8 & 10 & 1.29 & 1.00 \\
\hline 9 & Upper & 1.20 & 1.54 & 0.40 & 10 & 32 & 0 & 8 & 8 & 1.37 & 0.77 \\
\hline 10 & Upper & 1.09 & 1.27 & 0.06 & 5 & 77 & 0 & 7 & 5 & 1.58 & 0.90 \\
\hline 11 & Upper & 2.03 & 1.35 & 0.91 & 30 & 68 & 0 & 9 & 8 & 2.42 & 1.58 \\
\hline 12 & Upper & 1.53 & 1.14 & 0.46 & 15 & 86 & 64 & 6 & 8 & 1.75 & 1.74 \\
\hline 13 & Upper & 0.83 & 1.60 & 0.24 & 30 & 50 & 65 & 8 & 0 & 0.98 & 0.80 \\
\hline 14 & Upper & 1.77 & 1.41 & 0.24 & 10 & 35 & 72 & 7 & 0 & 1.80 & 1.11 \\
\hline 15 & Upper & 0.89 & 1.35 & 0.29 & 15 & 56 & 0 & 8 & 5 & 1.46 & 0.91 \\
\hline 16 & Lower & 1.61 & 1.35 & 0.15 & 40 & 10 & 50 & 5 & 0 & 2.32 & 0.63 \\
\hline 17 & Lower & 1.58 & 1.55 & 0.15 & 30 & 18 & 50 & 5 & 0 & 1.97 & 0.63 \\
\hline 18 & Lower & 1.53 & 1.57 & 0.30 & 20 & 24 & 0 & 5 & 0 & 2.47 & 0.81 \\
\hline 19 & Lower & 2.37 & 2.05 & 0.15 & 20 & 20 & 30 & 5 & 0 & 2.47 & 0.81 \\
\hline 20 & Lower & 2.07 & 1.77 & 0.15 & 30 & 14 & 50 & 5 & 0 & 2.41 & 1.13 \\
\hline 21 & Lower & 1.85 & 1.55 & 0.15 & 25 & 16 & 50 & 5 & 0 & 2.29 & 1.30 \\
\hline 22 & Lower & 1.81 & 1.51 & 0.15 & 30 & 15 & 30 & 5 & 0 & 0.51 & 0.94 \\
\hline 23 & Lower & 1.60 & 1.14 & 0.30 & 15 & 20 & 50 & 5 & 0 & 1.91 & 0.95 \\
\hline 24 & Lower & 1.43 & 1.55 & 0.30 & 50 & 22 & 50 & 5 & 0 & 1.59 & 0.93 \\
\hline
\end{tabular}


Appendix H: Streambank site photos

Site 1

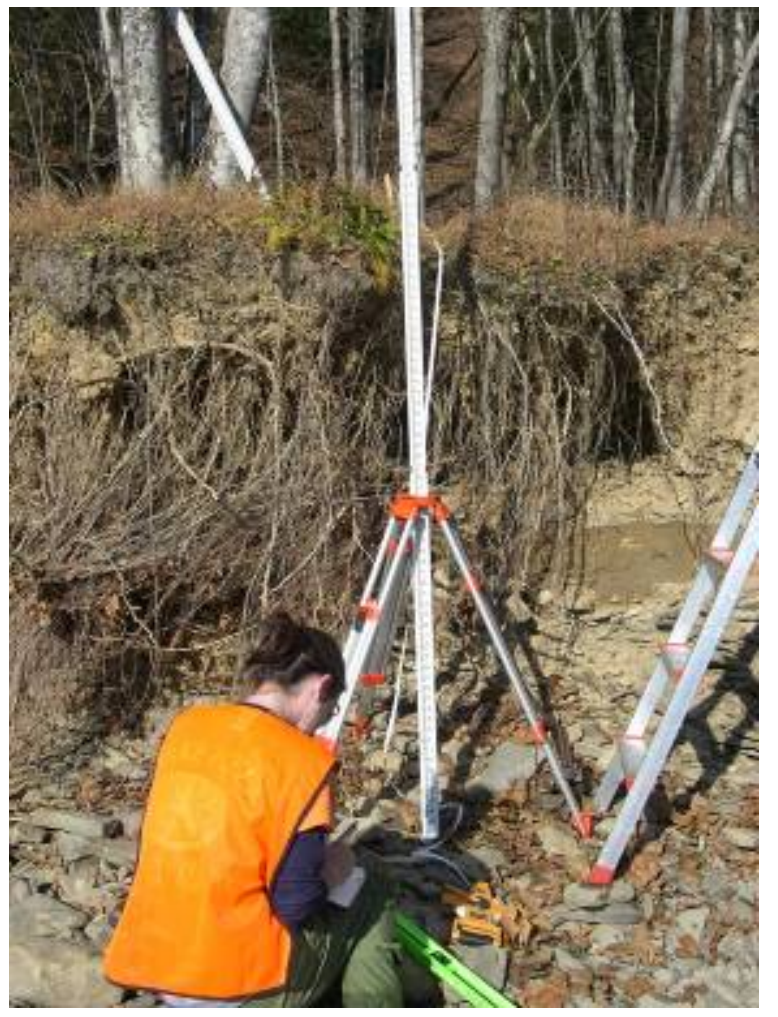

Site 3

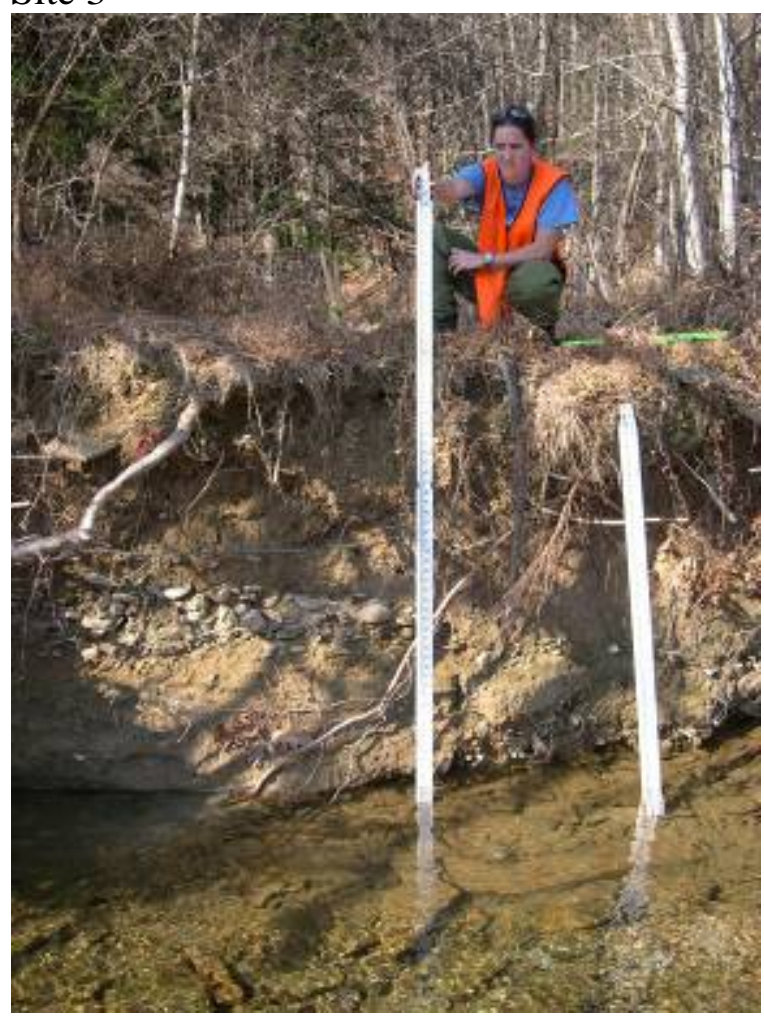

Site 2

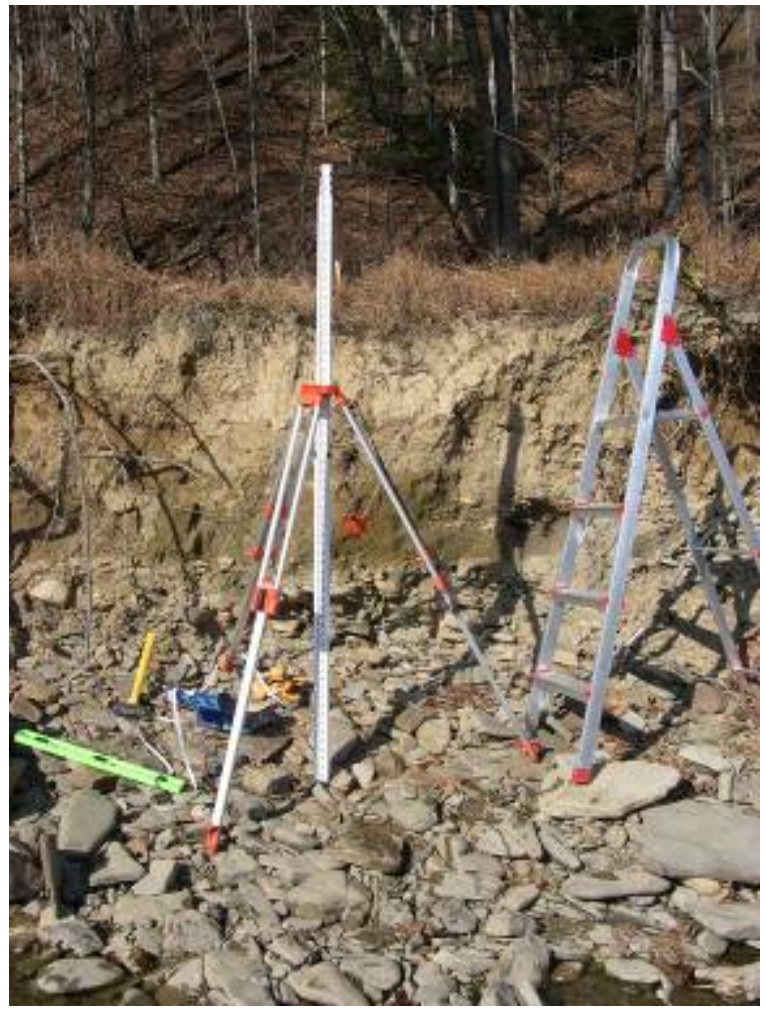

Site 4

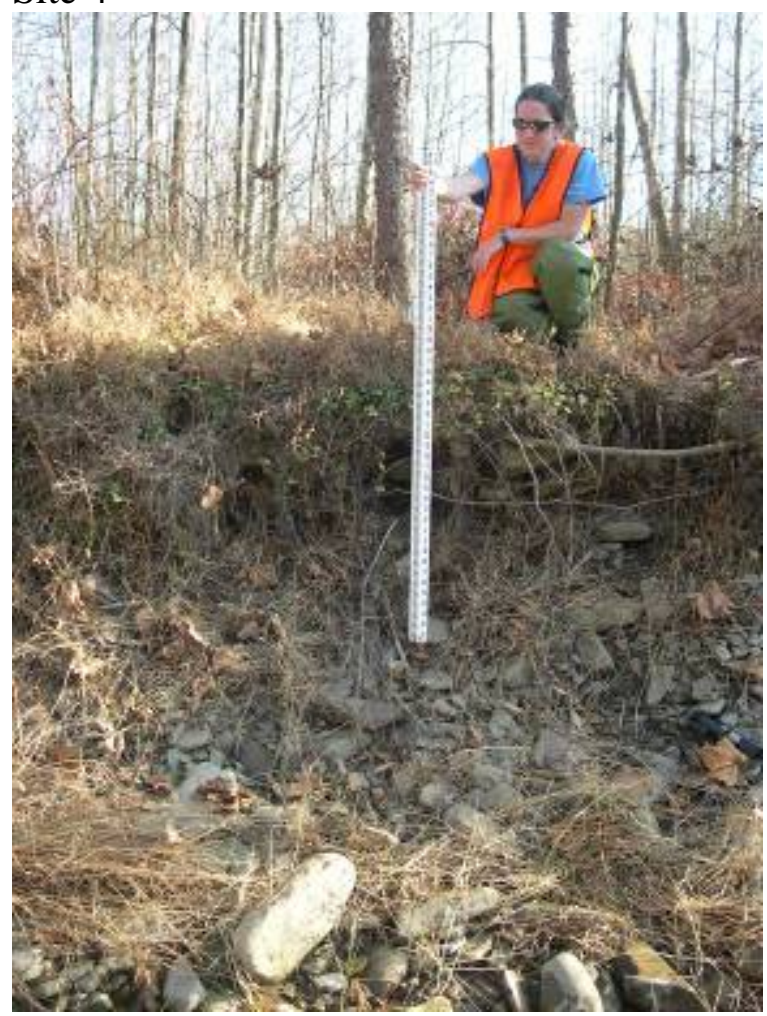


Site 5

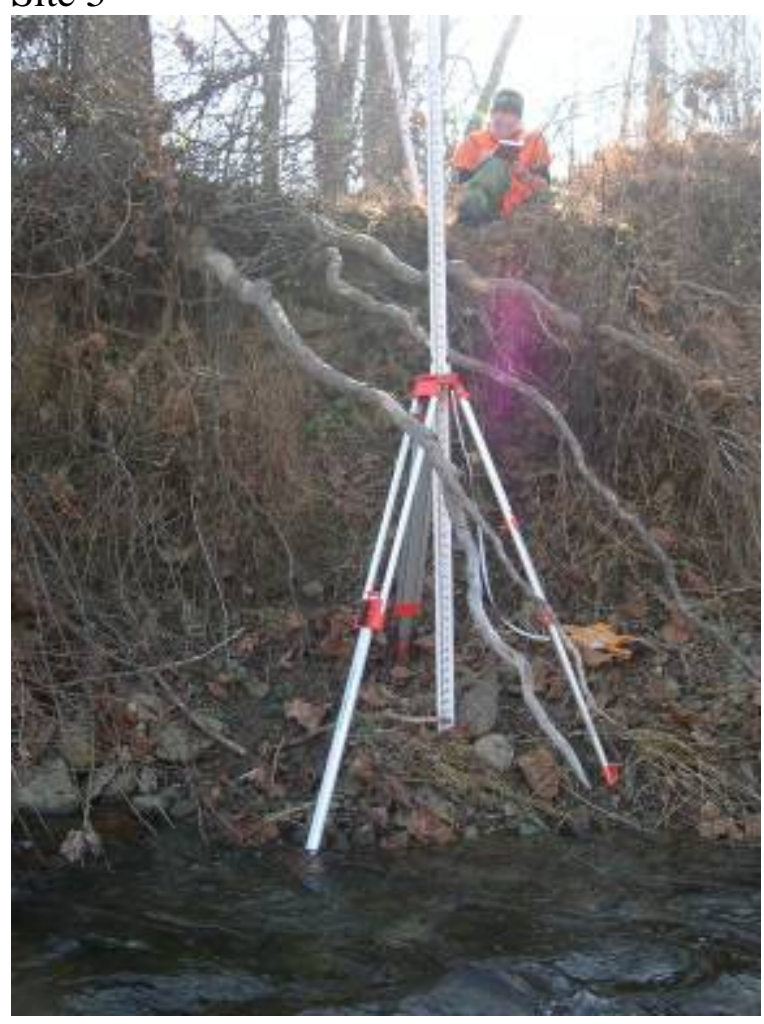

Site 7

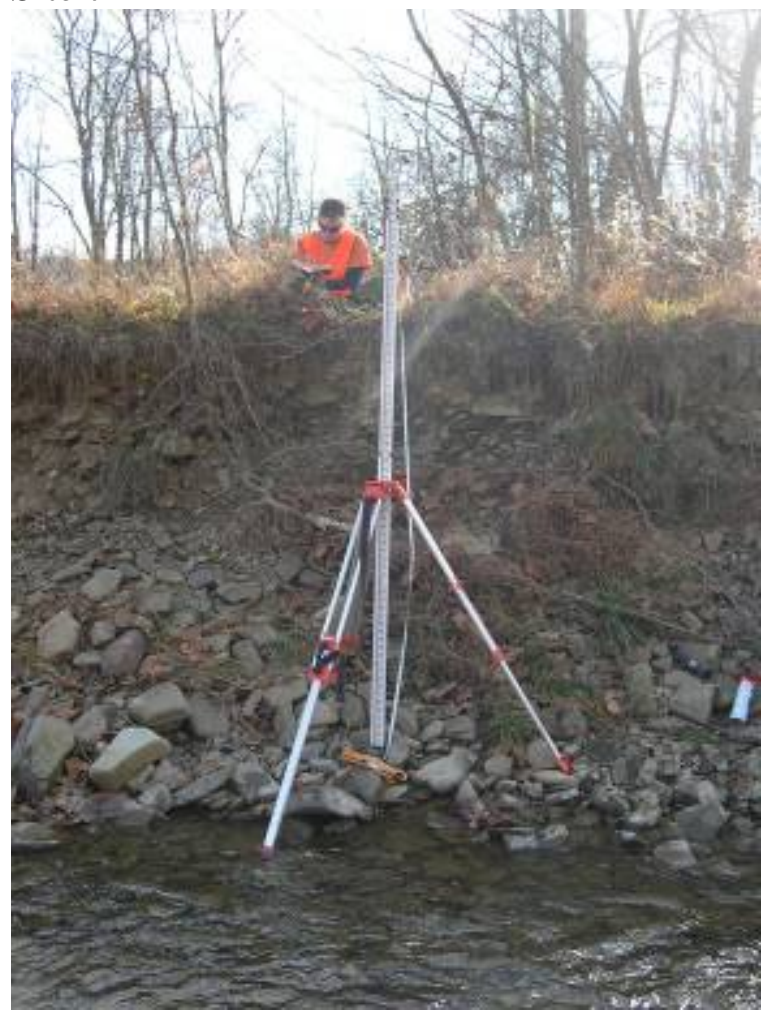

Site 6



Site 8

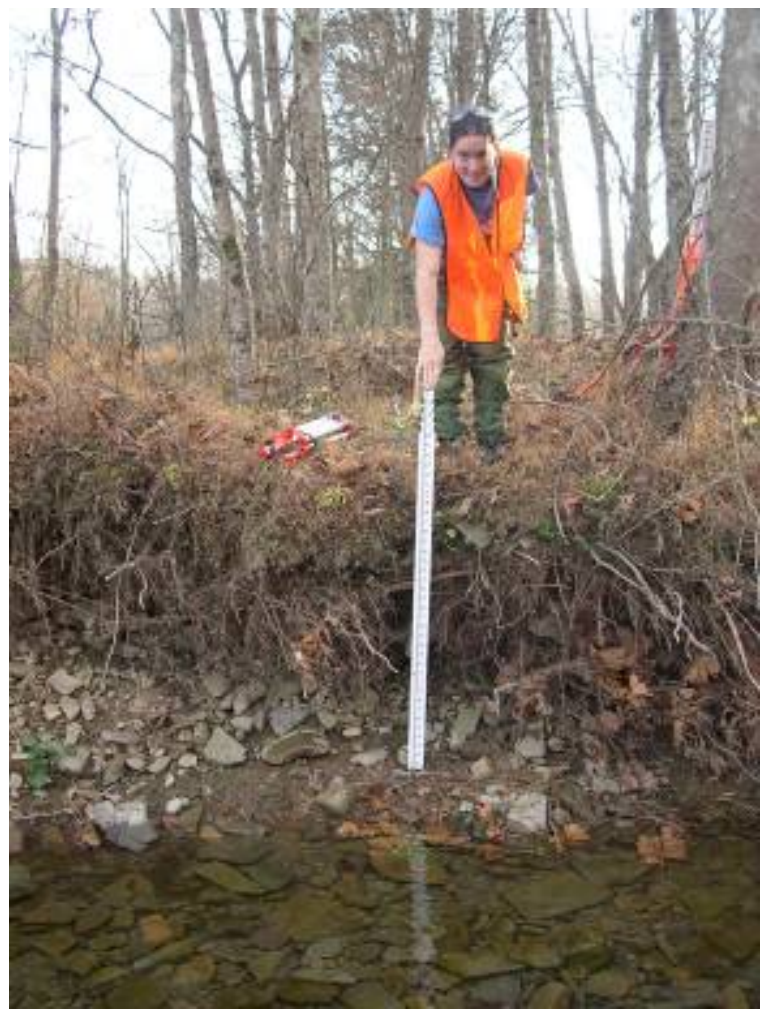


Site 9

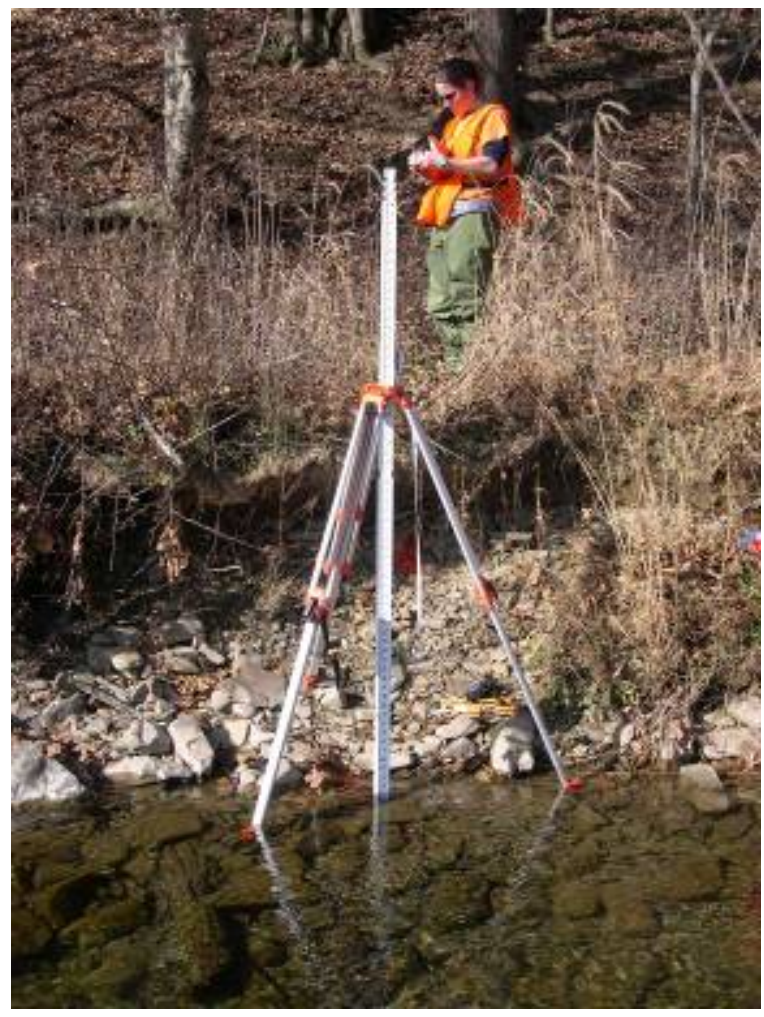

Site 11

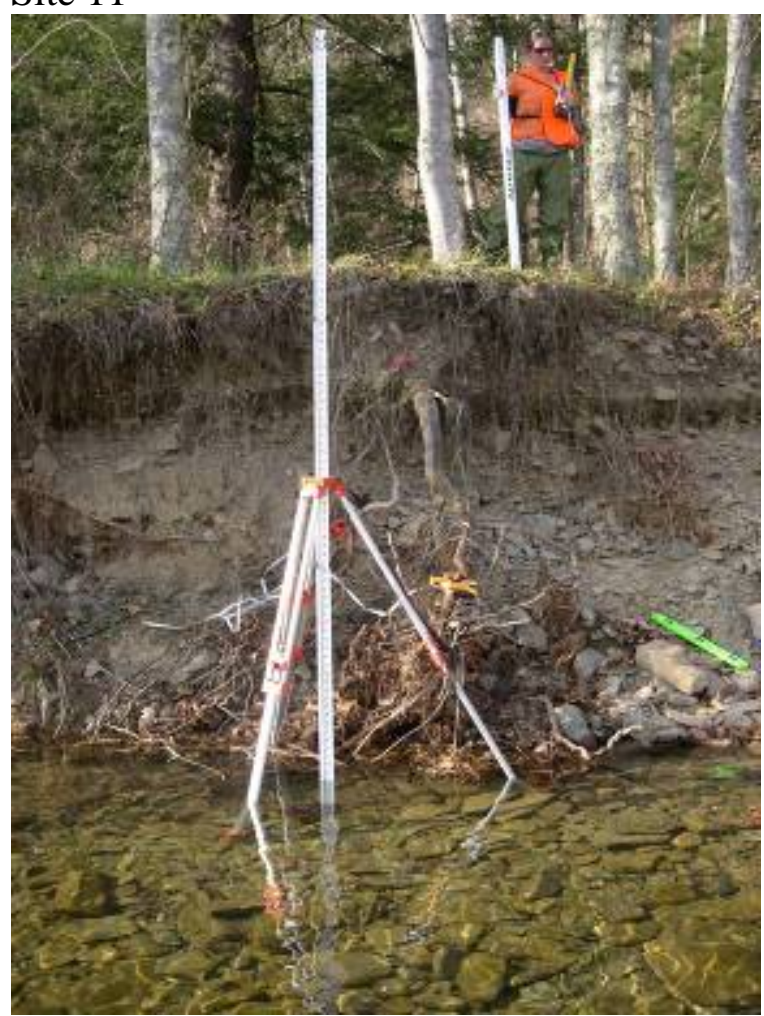

Site 10

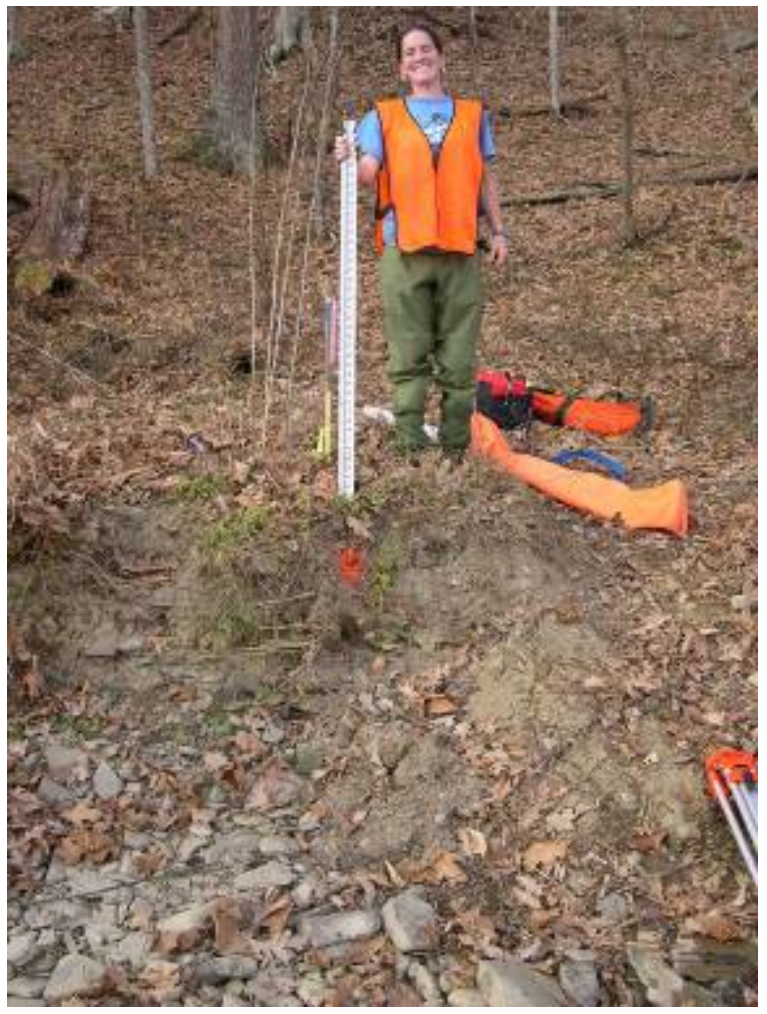

Site 12

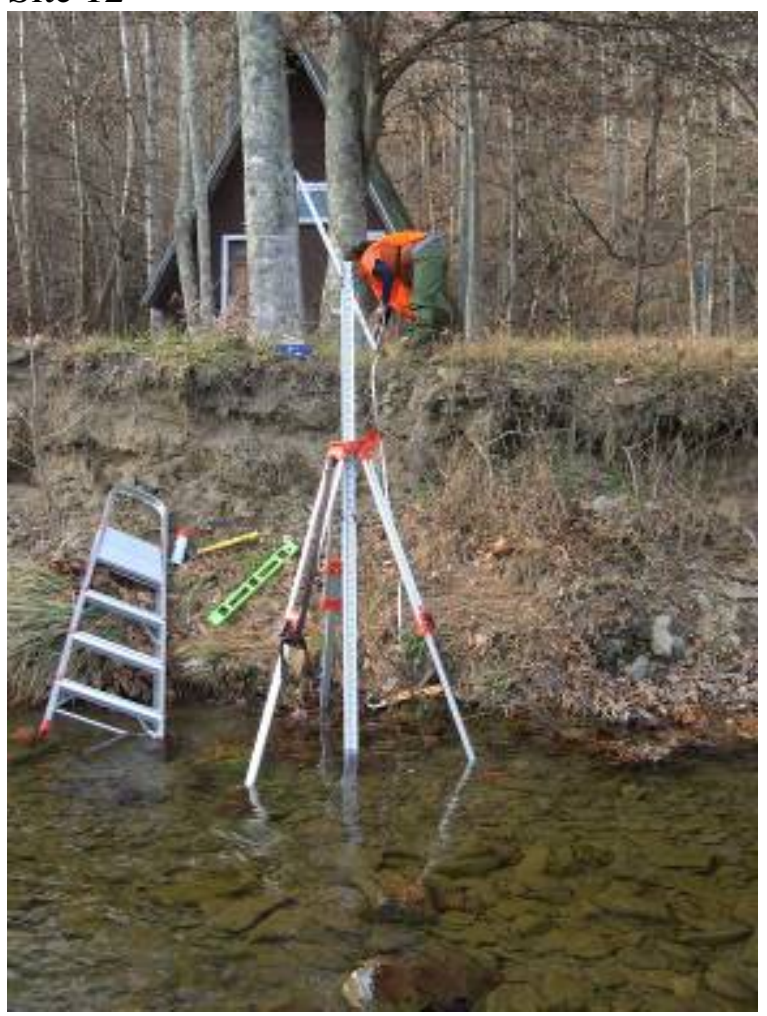


Site 13

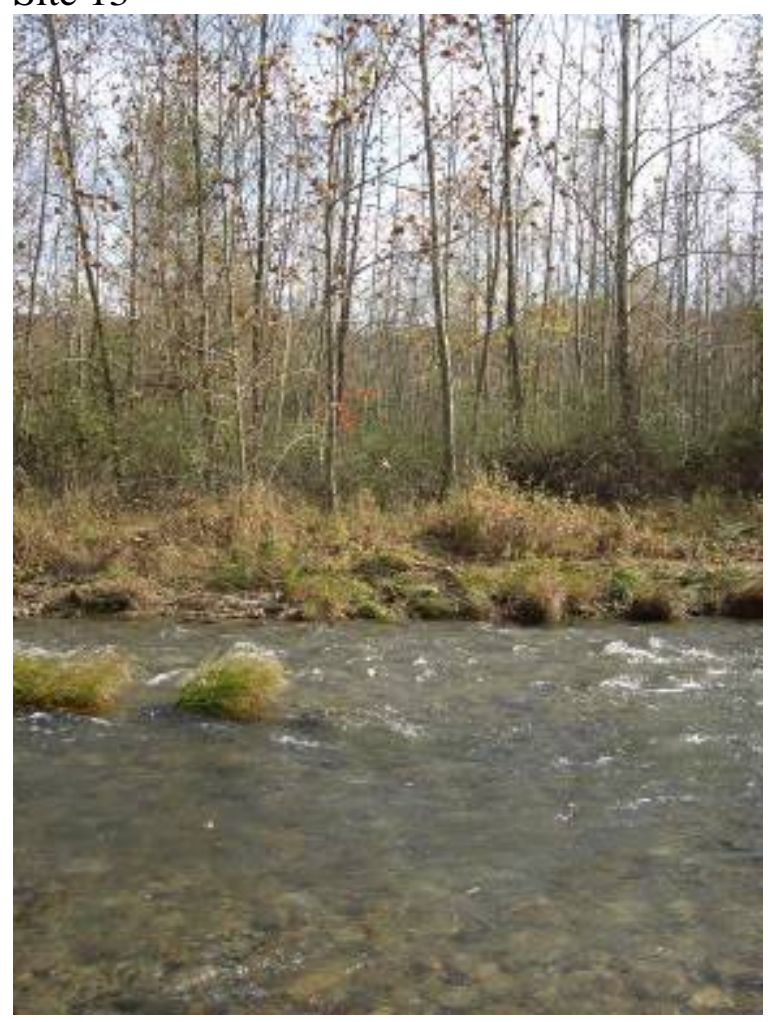

Site 15

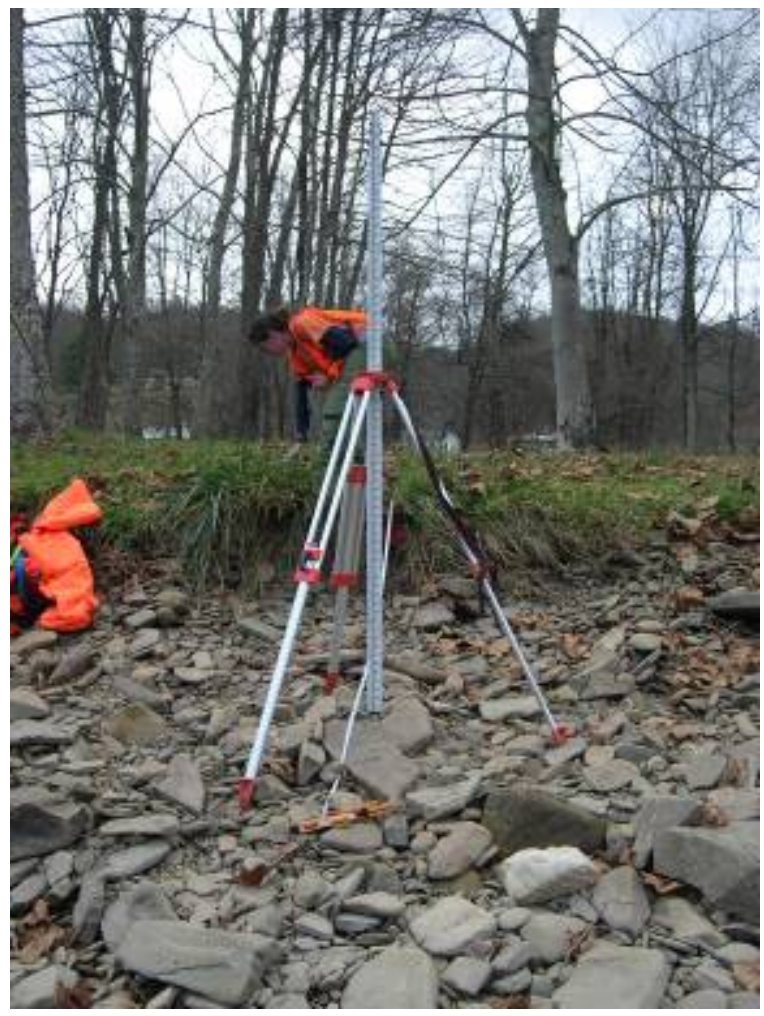

Site 14

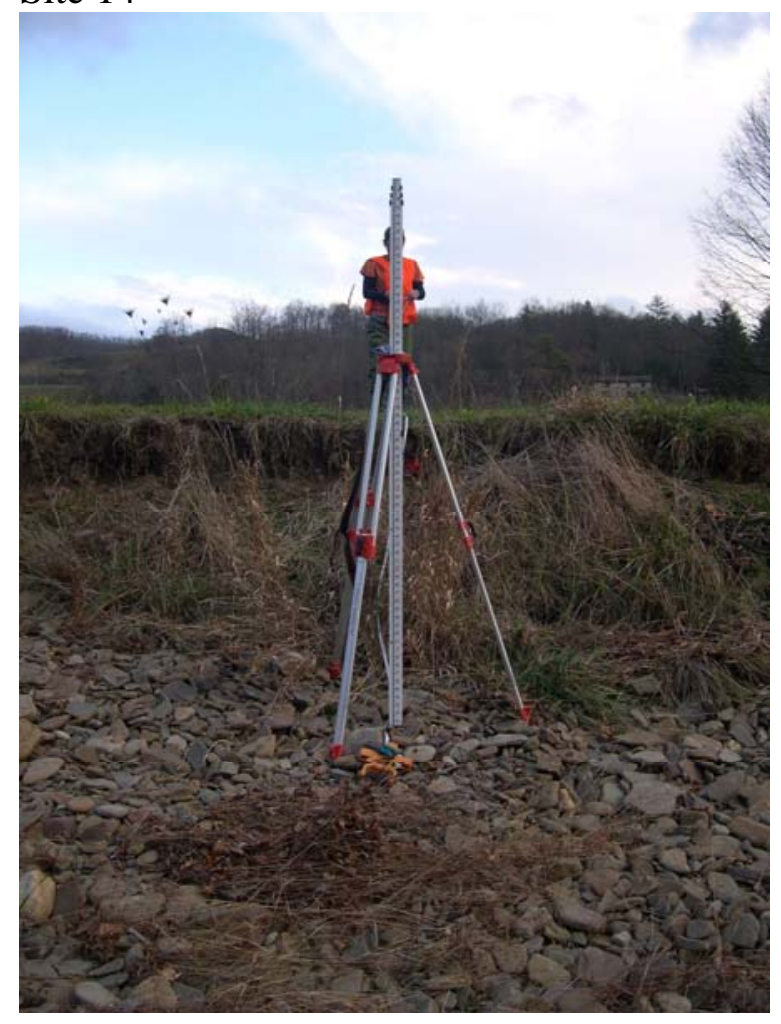

Site 16




Site 17
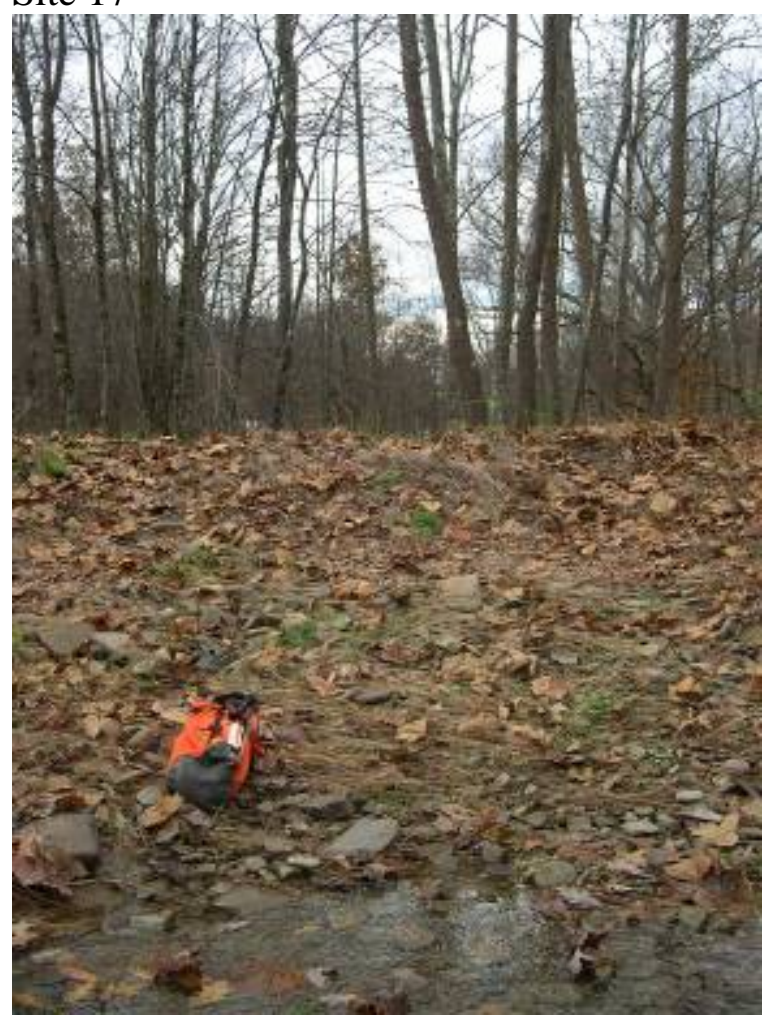

Site 19



Site 18



Site 20

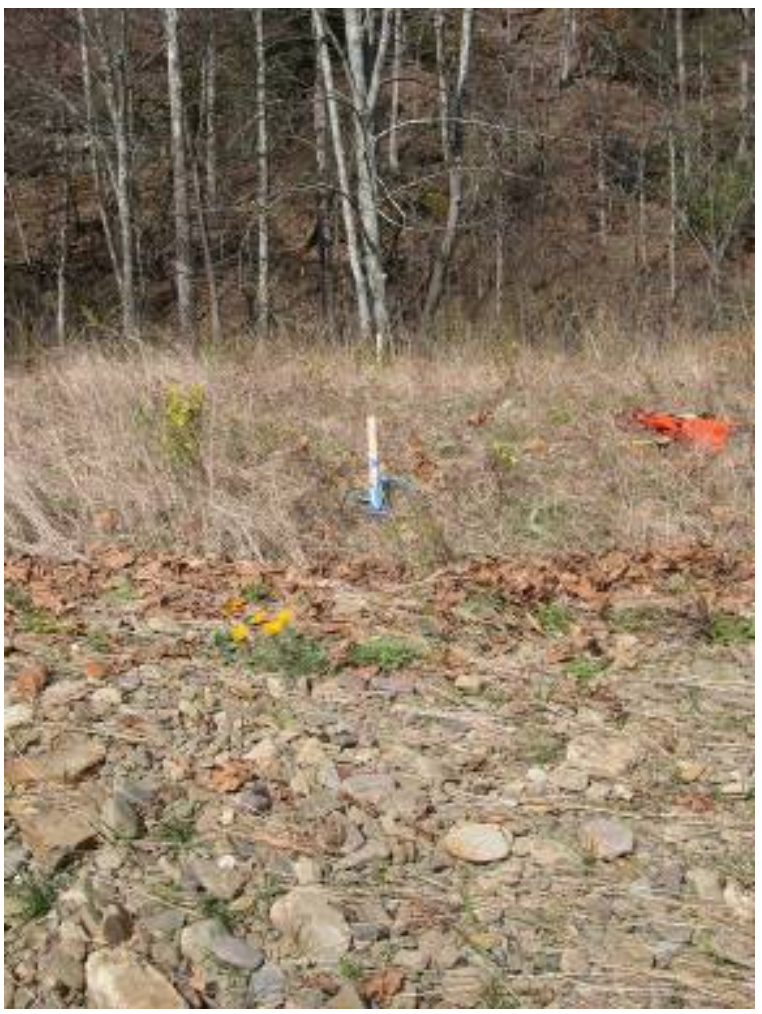


Site 21

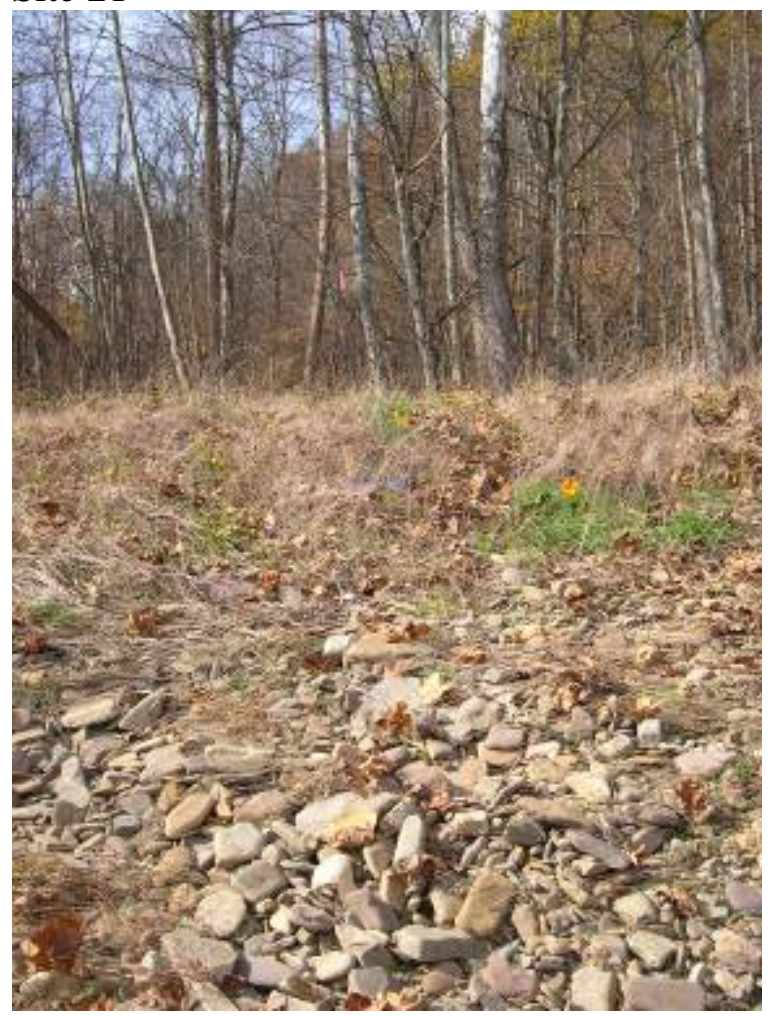

Site 23

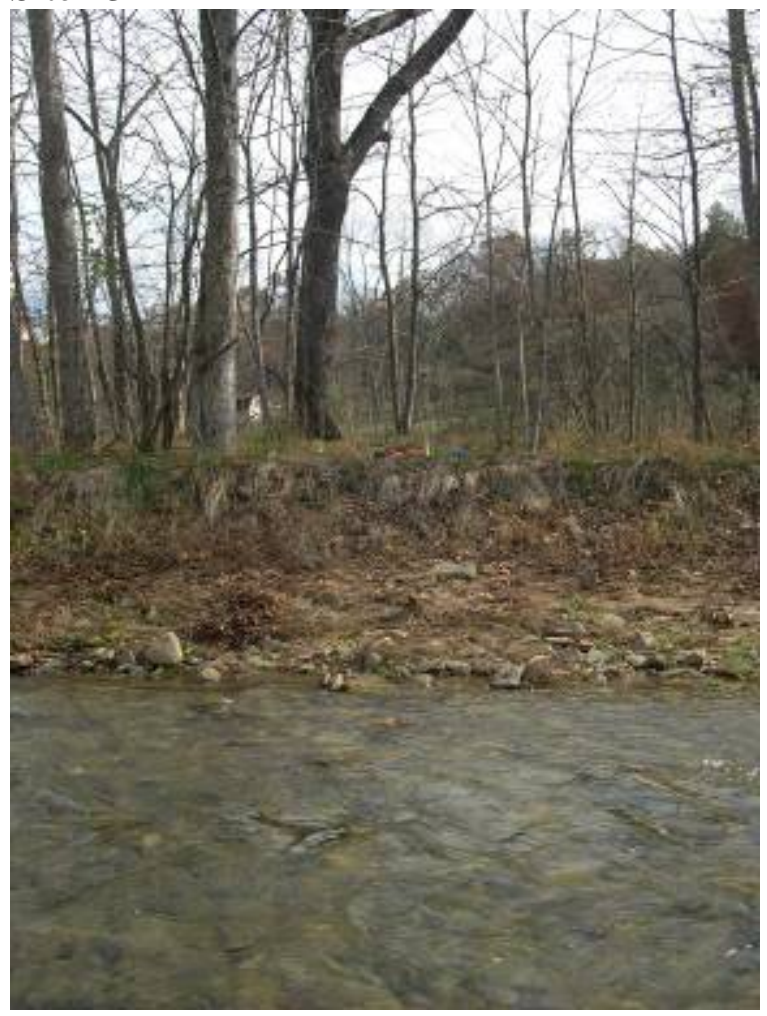

Site 22

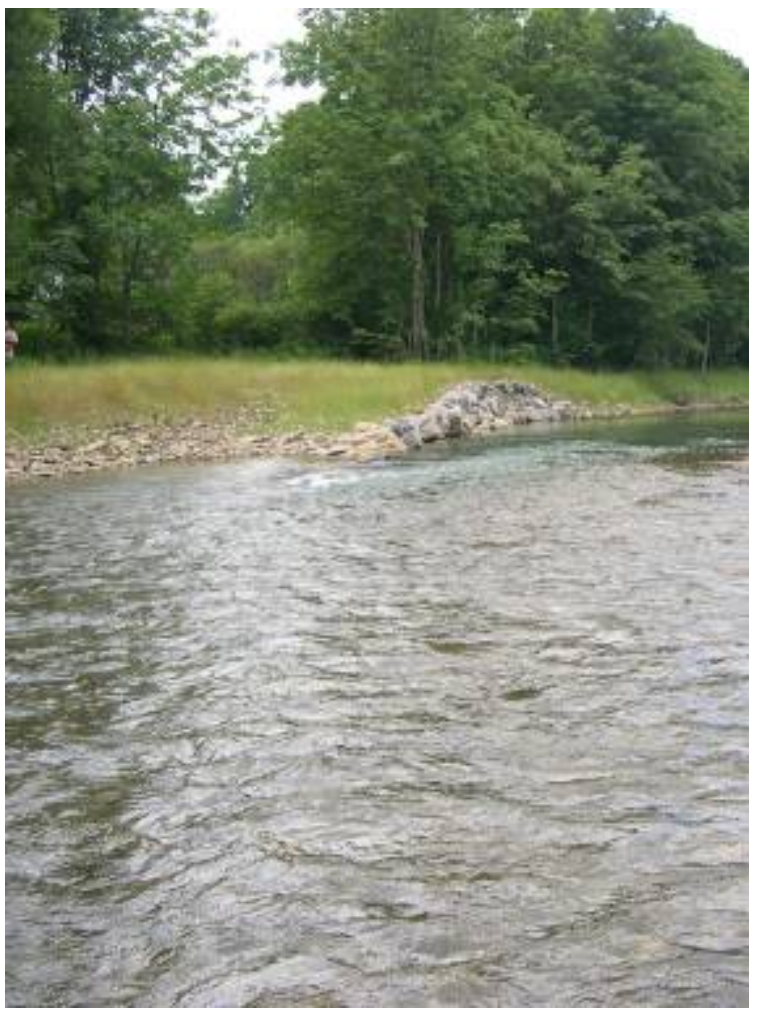

Site 24

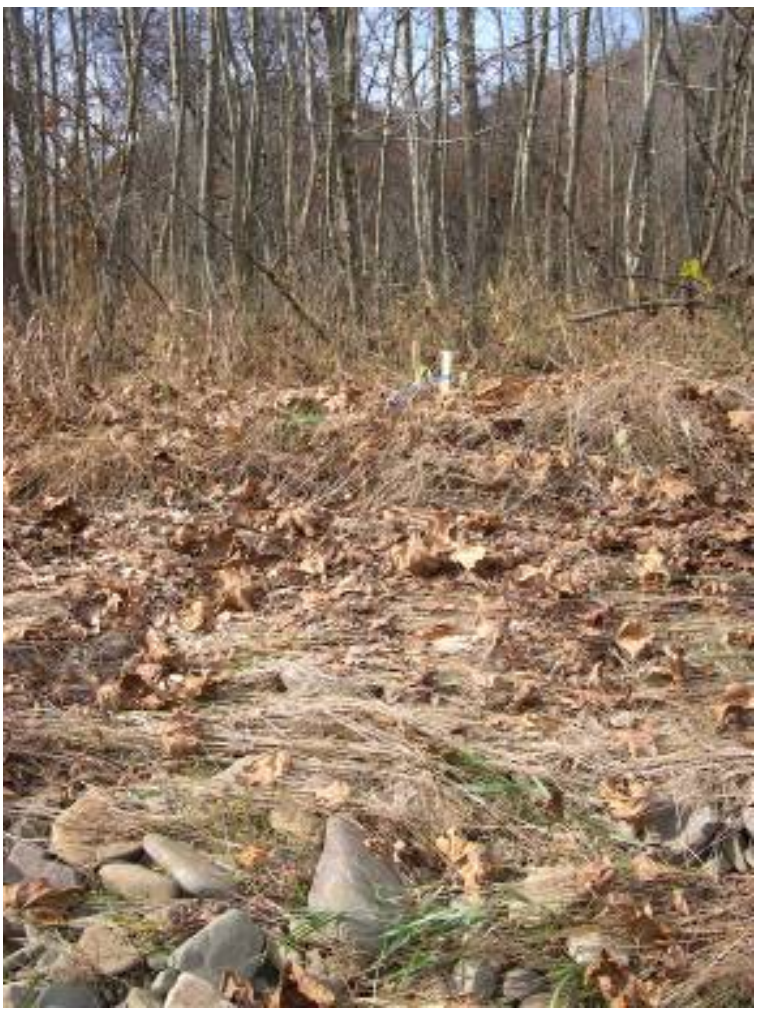

John $\mathrm{H}$.

Virginia University Libraries,
ou=Acquisitions Department,
email=John.Hagen@mailwvilu

Hagen $\begin{aligned} & \text { email=John.Hagen@mail.wvu.edu } \\ & \text { c=Us } \\ & \text { Date: 2011.08.02 16:20:44-04'00' }\end{aligned}$ 